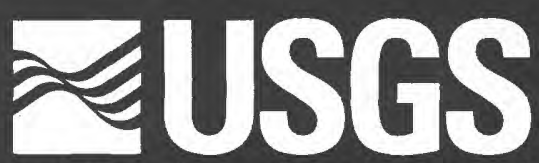

science for a changing world

Prepared in cooperation with

Water Programs Rivers Division,

Pierce County Public Works And Utilities

\title{
Real-Time Flood Alert and Simulation of River Flood Discharges in the Puyallup River Basin, Washington
}

Water-Resources Investigations Report 98-4226

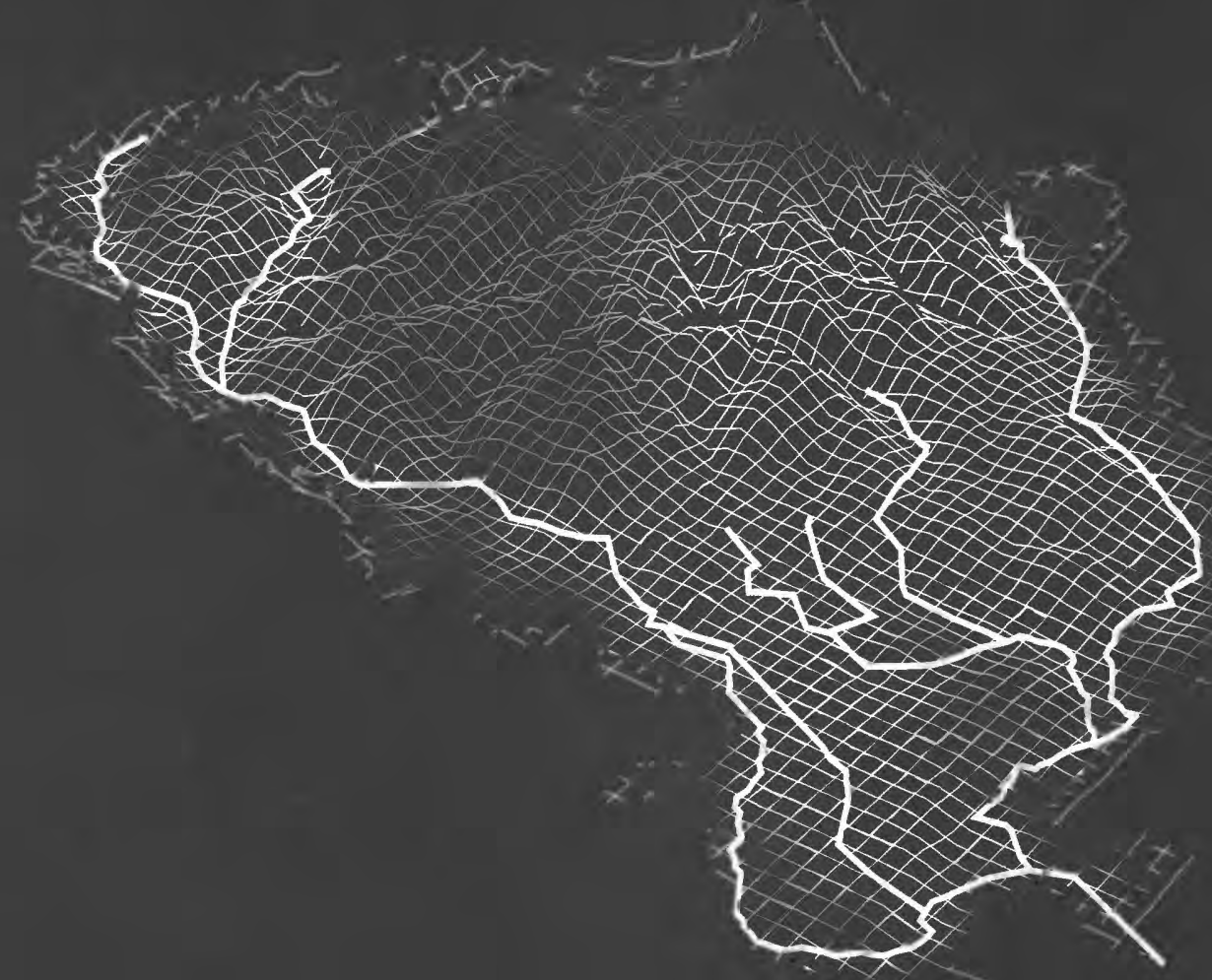

U.S. Department of the Interior U.S. Geological Survey 



\section{Real-Time Flood Alert and Simulation of River Flood Discharges in the Puyallup River Basin, Washington}

By M.C. Mastin

U.S. Geological Survey

Water-Resources Investigations Report 98-4226

Prepared in cooperation with

WATER PROGRAMS RIVERS DIVISION,

PIERCE COUNTY PUBLIC WORKS AND UTILITIES 


\section{U.S. DEPARTMENT OF THE INTERIOR}

BRUCE BABBITT, Secretary

\section{U.S. GEOLOGICAL SURVEY}

Charles S. Groat

Director

Any use of trade, product, or firm names is for descriptive purposes only and does not imply endorsement by the U.S. Government.

For additional information write to:

District Chief

U.S. Geological Survey

1201 Pacific Avenue - Suite 600

Tacoma, Washington 98402
Copies of this report may be purchased from:

U.S. Geological Survey

Branch of Information Services

Box 25286

Denver, Colorado 80225-0286 


\section{CONTENTS}

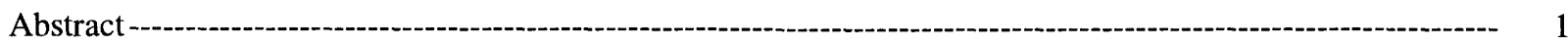

Introduction -

Purpose and scope -

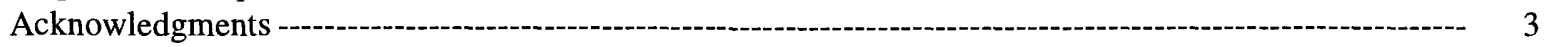

Description of study area and data-collection network - 3

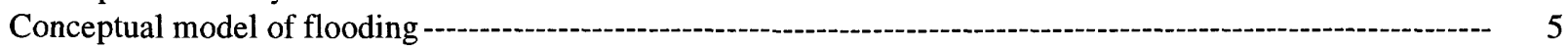

Flood history - 7

Meteorological conditions related to flooding -

Generalizations about flooding in the Puyallup River Basin -

Description of the numerical model -

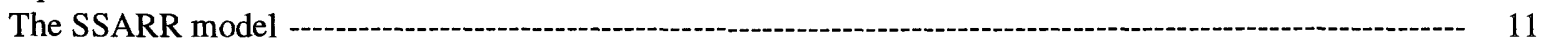

Subdivision of the Puyallup River Basin into subbasins and elevation zones --.-.-.-.-.- 12

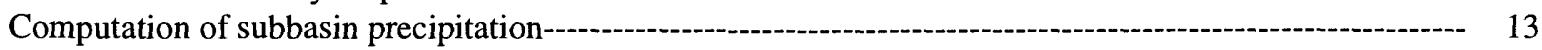

Adjusting meteorological data inputs for elevation ---10.-14

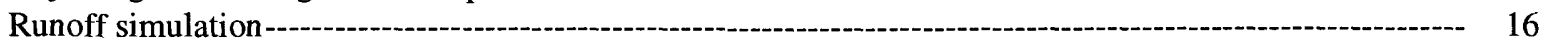

Snow accumulation, conditioning, and melt -

Partitioning moisture inputs--

Routing of surface, subsurface, and base flow runoff from subbasins to streams -

Stream network--

Flow in channels and reservoirs -

Automated adjustment of simulated runoff -

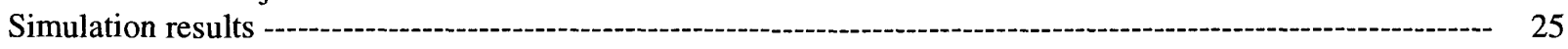

Approach to calibration and validation of the numerical model-

Calibration and validation of the numerical model-- 26

Comparison of simulated extent of snow cover with observed extent -

Comparison of observed and simulated runoff -

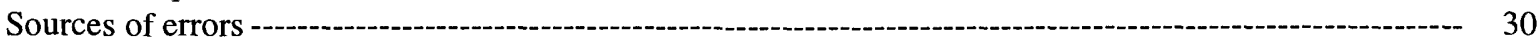

Sensitivity analysis of precipitation and temperature inputs and snow-water equivalence on

simulated discharge--

Influence of precipitation inputs on simulated results --

Influence of the number of temperature inputs on simulated results -

Influence of simulated snow-water equivalence on simulated runoff---

Model limitations -- 40

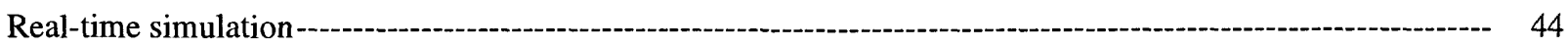

Overview of the Puyallup Flood-Alert System ----.--

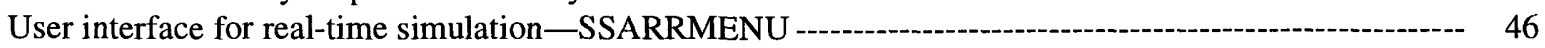

General procedure for using SSARRMENU

Example of a real-time simulation--

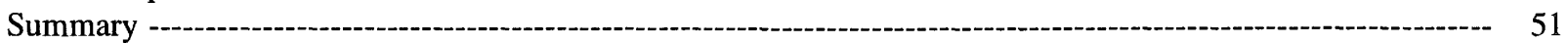

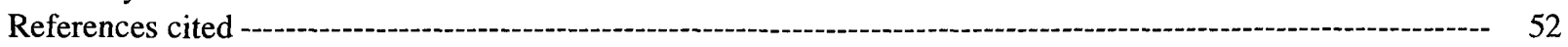

Appendix A. SSARR-code names, characteristics files, and tabled characteristics -...-...- 54

\section{FIGURES}

1. Map of study area, showing the Puyallup River, its major tributaries, and its basin boundaries -------

2. Diagram showing generalized flowpath of hydrological and meteorological data from the gage sites to the Pierce County River Improvement office and within the computer for the Puyallup Flood-Alert System 


\section{FIGURES--Continued}

3. Map showing streamflow and meteorological network of U.S. Geological Survey-operated gages in the Puyallup River Basin, Washington

4. Hydrographs showing comparison of runoff response to precipitation between an early fall and early winter storm at two gaging stations in the Puyallup River Basin, Washington---------.---- 10

5. Map showing weather stations and mean annual precipitation in the Puyallup River Basin, Washington

6. Graph showing mean annual precipitation as a function of elevation in the Puyallup River Basin and subbasins, Washington -

7. Flow chart of the simulated runoff from a snowband for the Puyallup River Basin model, Washington

8. Schematic diagram of the network of subbasin, channel reaches, reservoirs, and summing points used in the Puyallup River Basin model, Washington-

9. Graph of simulated hourly subbasin runoff response to liquid water input defined by table ATTR1 in the Puyallup River Basin model, Washington -

. Hydrograph of simulated outflow discharge from REACH2 of the Puyallup River Basin model, simulated ungaged inflow to REACH2, observed upstream inflow to REACH2 at White River at Buckley, and observed outflow at White River near Auburn during February 5-12, 1996, Puyallup River Basin, Washington-

11. Graph showing preliminary and final runoff percentage (ROP) curves for the upper Puyallup subbasin in the Puyallup River Basin model, Washington

12. Graphs showing observed and simulated storm runoff volumes and peak discharge for South Prairie, upper Puyallup, Greenwater, and Carbon subbasins and summation point SUM1, Washington

13-14. Hydrographs of observed and simulated discharge at Puyallup River near Orting, Carbon River near Fairfax, South Prairie Creek at South Prairie, and Greenwater River at Greenwater, Puyallup River Basin, Washington, for the

13. November 29 to December 3, 1994, storm--

14. February 7-11, 1996, storm --

15. Computer screen display of the Puyallup River Basin, Washington, flood-alert map from the SSARRMENU program

16. Schematic and description of menu items for SSARRMENU

17. Hydrographs of simulated discharge and subbasin precipitation results from three model runs for the upper Puyallup subbasin in the Puyallup River Basin model and observed discharge at Puyallup River near Orting, station number 12093500, Pierce County, Washington

\section{TABLES}

1. Normal monthly and annual precipitation, base period $1961-90$, for selected National Weather Service stations in or near the Puyallup River Basin, Washington-

2. Ten largest annual peak discharges (ranks 1 through 10) for selected stations in the Puyallup River Basin, Washington, and the annual peak flows used during the model calibration and validation period of this study (1994-97 water years)

3. Meteorological conditions at four National Weather Service stations for the eight largest floods since 1965 at the U.S. Geological Survey gaging station Puyallup River at Puyallup, Washington -

4. Area of elevation zones by subbasin used in the Puyallup River Basin model, Washington--

5. Priority matrix for selecting two rain-gage records and normal annual precipitation used to compute a subbasin precipitation record, Puyallup River Basin, Washington 


\section{TABLES--Continued}

6. Priority matrixes for selecting a single temperature record and a pair of temperature records to compute subbasin snowband temperature and subbasin temperature lapse rates, Puyallup River Basin, Washington

7. Definition of indexes, parameters, and tables used in the model characteristic file that define the hydrologic processes and parameters used in the Puyallup River Basin model, Washington -------

8. Comparison of observed snow-pillow snow-water equivalent values and National Operational Hydrologic Remote Sensing Center estimates of snow-water equivalent at three sites in or near the Puyallup River Basin, Washington

9. Snow-water equivalent for 5 upper basins and for all 13 elevation zones in the Puyallup River Basin, Washington, computed from National Operational Hydrologic Remote Sensing Center (NOHRSC) estimates and simulated by the Puyallup River Basin model, Washington, for 4 days in February 1996

10. Observed and simulated storm runoff values per unit area and peak discharge of eight storms used for calibration and validation of the Puyallup River Basin model, Washington-

11. Summation of errors of storm runoff and peak discharge for the five gaged subbasins in the Puyallup River Basin model, Washington

12. Observed storm precipitation totals at Nevan-McCullough Seed Orchard Meteorological site and estimated 8-day precipitation totals for snowband 3, subbasin UPWHT, calculated from three different pairs of precipitation stations-

13. Simulated discharge at four upper Puyallup subbasins, Washington, for two storms in water year 1996 using different combinations of precipitation inputs -

14. Simulated discharge at four upper Puyallup subbasins, Washington, for two storms in water year 1996 using different combinations of temperature inputs

15. Storm runoff and peak discharge for February 5-9, 1996, from four model runs that show the model's sensitivity to pre-storm snow-water equivalent for four upper subbasins in the Puyallup River Basin, Washington

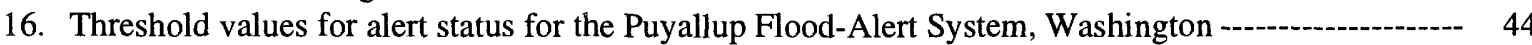

17. Example of the quantitative precipitation file, SEA.QPF, and temperature forecast file, GRF.WMO, from the National Weather Service for use in the Puyallup River Basin model, Washington

\section{CONVERSION FACTORS, VERTICAL DATUM, AND ABBREVIATIONS}

\begin{tabular}{lcl}
\hline & Multiply & \multicolumn{1}{c}{ To obtain } \\
\hline inch (in.) & 25.4 & millimeter \\
inch per hour & 25.4 & millimeter per hour \\
inch per year & 25.4 & millimeter per year \\
foot (ft) & 0.3048 & meter \\
foot per second $(\mathrm{ft} / \mathrm{s})$ & 0.3048 & meter per second \\
mile (mi) & 1.609 & kilometer \\
mile per hour $(\mathrm{m} / \mathrm{h})$ & 1.609 & kilometer per hour \\
square mile $\left(\mathrm{mi}^{2}\right)$ & 2.590 & square kilometer \\
acre-foot $(\mathrm{acre}-\mathrm{ft})$ & 1,233 & cubic meter \\
cubic foot per second $\left(\mathrm{ft}^{3} / \mathrm{s}\right)$ & 0.02832 & cubic meter per second
\end{tabular}




\section{CONVERSION FACTORS, VERTICAL DATUM, AND ABBREVIATIONS-Continued}

Temperature: To convert temperature given in this report in degrees Fahrenheit $\left({ }^{\circ} \mathrm{F}\right)$ to degrees Celsius $\left({ }^{\circ} \mathrm{C}\right)$, use the following equation: ${ }^{\circ} \mathrm{C}=5 / 9\left({ }^{\circ} \mathrm{F}-32\right)$.

Sea Level: In this report "sea level" refers to the National Geodetic Vertical Datum of 1929 (NGVD of 1929)--a geodetic datum derived from a general adjustment of the first-order level nets of both the United States and Canada, formerly called Sea Level Datum of 1929.

Elevation: In this report, "elevation" is measured in feet above sea level.

\section{ABBREVIATIONS}

$\begin{array}{ll}\text { ADAPS } & \text { Automated Data Processing System } \\ \text { CROHMS } & \text { Columbia River Operations Hydromet Management System } \\ \text { DEM } & \text { Digital elevation model } \\ \text { GIS } & \text { Geographic information system } \\ \text { NAP } & \text { Normal annual precipitation } \\ \text { NOHRSC } & \text { National Operational Hydrologic Remote Sensing Center } \\ \text { NRCS } & \text { National Resources Conservation Services } \\ \text { NWS } & \text { National Weather Service } \\ \text { PC } & \text { Personal computer } \\ \text { PCRI } & \text { Pierce County River Improvement } \\ \text { SEE } & \text { Standard error of estimate } \\ \text { SSARR } & \text { Streamflow Synthesis and Reservoir Regulation model } \\ \text { SWE } & \text { Snow-water equivalent } \\ \text { USACOE } & \text { U.S. Army Corps of Engineers } \\ \text { WAR } & \text { Water available for runoff } \\ \text { WATSTORE } & \text { National Water Data Storage and Retrieval System }\end{array}$




\title{
REAL-TIME FLOOD ALERT AND SIMULATION OF RIVER FLOOD DISCHARGES IN THE PUYALLUP RIVER BASIN, WASHINGTON
}

\author{
By M. C. Mastin
}

\begin{abstract}
The U.S. Geological Survey, in cooperation with Pierce County, Washington, has developed an operational tool called the Puyallup Flood-Alert System to alert users of impending floods. The system acquires real-time meteorological and hydrological data to make real-time flood simulations of discharge in the major rivers of the Puyallup River Basin and provides a flood-alert computer display. The system consists of a network of U.S. Geological Survey-operated river discharge and stage, precipitation, and temperature gages; a numerical watershed runoff and streamflow-routing model; and a computer interface. A snowband version of the Streamflow Synthesis and Reservoir Regulation (SSARR) numerical model is the heart of the system that makes real-time and forecast simulations based on real-time data from the gaging network and precipitation and temperature forecasted by the National Weather Service.
\end{abstract}

The watershed model was calibrated against observed peak discharge and runoff volumes from five subbasins during four storms in water years 1995 and 1996 and validated with similar data from four storms in the 1996 and 1997 water years. Two-thirds of the simulated peak discharges for the calibration storms were within 36 percent of the observed peak discharges, and two-thirds of the 5-day runoff volumes were within 17 percent of observed runoff volumes. For the validation storms, the corresponding values were 30 percent and 24 percent, respectively.

SSARRMENU, a customized user interface for the Puyallup Flood-Alert System, is the central software that provides a graphical display of flood-alerts and model input and output, makes retrievals of hydrologic and meteorological data from the U. S. Geological Survey computer, and initiates simulations by SSARR. With SSARRMENU operating on its computer, Pierce County has an increased ability to evaluate current and near-future floods and to efficiently allocate its resources to potential trouble spots.

\section{INTRODUCTION}

Flooding on the Puyallup River and its major tributaries threatens people and property as the river weaves through increasingly urban areas from the western foothills of the Cascade Range to Puget Sound in the City of Tacoma (fig. 1). Most of the basin lies within Pierce County, and Pierce County River Improvement or PCRI (also known as the Water Programs Rivers Division), an agency of Pierce County Public Works and Utilities, has primary responsibility for floodplain management and maintaining the flood-control levees of the major rivers in the basin. The agency monitors river levels and weather forecasts closely during the rainy season (November through March) and allocates its resources in response to current and imminent flooding. To allocate its resources efficiently for impending flooding, the agency needed a monitoring and predictive tool to assess the size and timing of peak flows at critical locations.

The U.S. Geological Survey (USGS), in cooperation with PCRI, has developed a real-time flood-alert tool that personnel of PCRI can operate on their computers using real-time data gathered at USGS-operated gaging stations and quantitative temperature and precipitation forecasts made by the National Weather Service (NWS). This real-time flood-alert tool, an operational system called the "Puyallup Flood-Alert System," provides graphic and tabular information on current river discharges and stages in the Puyallup River Basin, simulated river discharges and stages, as well as 2-day river forecasts based on meteorological forecasts by the Seattle NWS office. Two versions of the software that provides users an interface to the system were developed-one runs on a MS-DOS ${ }^{\mathrm{TM}}$ or Windows $3.1^{\mathrm{TM}}$ operating system and one runs on a Windows $\mathrm{NT}^{\mathrm{TM}}$ operating system. 


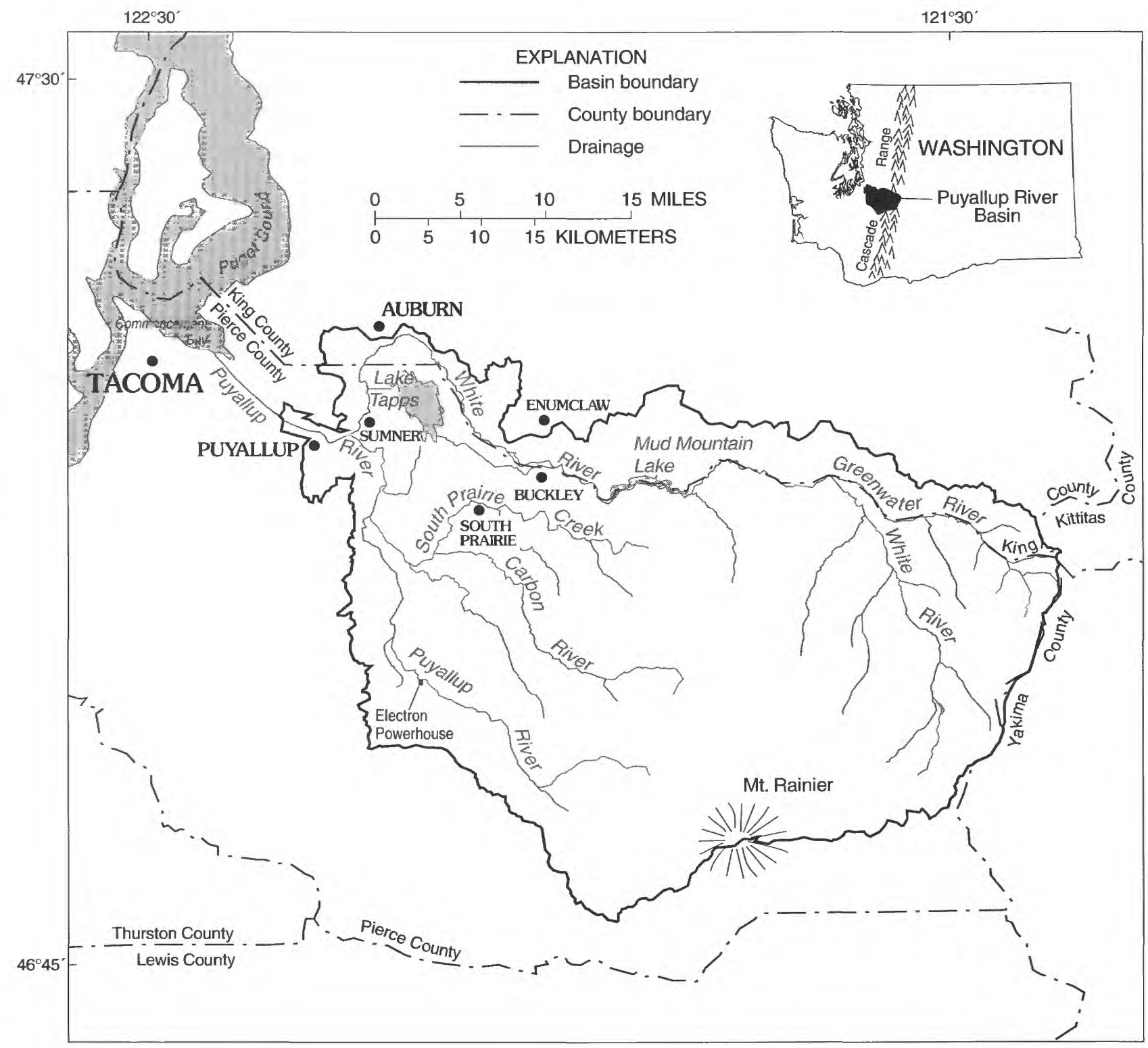

Figure 1. Study area showing the Puyallup River, its major tributaries, and its basin boundaries. 


\section{Purpose and Scope}

This report describes (1) a conceptual model based on the main hydrologic and meteorologic influences on major floods in the Puyallup River Basin, (2) a numerical watershed and flow-routing model to simulate flooding in the Puyallup River and major tributaries, (3) the sensitivity of the model to various inputs and parameters, (4) an evaluation of the simulation model results, and (5) an operational system that provides real-time transfer of observed and forecasted meteorological and river data, real-time simulation of river discharges and stage, and real-time displays of observed and simulated meteorological and river data.

Before this work started, many streamgaging stations provided information via satellite telemetry to the USGS office and then via telephone to the PCRI. During the investigation, the USGS-operated hydrometeorological network was upgraded, and a meteorological site in the Puyallup River Basin was added to provide a more dense network of telemetered precipitation and temperature data. The Streamflow Synthesis and Reservoir Regulation (SSARR) model, a numerical model for simulating watershed runoff and streamflow routing, was calibrated to four observed peak flows during the 1995-96 water years and validated to four storms in the 1996-97 water years.

The Puyallup Flood-Alert System (fig. 2) is composed of the validated SSARR model that incorporates all the available telemetered meteorological and discharge data for the basin, the data base for observed and simulated data, and the compiled FORTRAN90 program SSARRMENU. SSARRMENU provides a graphical interface to the SSARR model so that users can make model runs and review the results with pull-down menus, dialog boxes, and a "point-and-click" map display.

\section{Acknowledgments}

The author wishes to acknowledge the NWS's River Forecast Center in Portland, Oreg., for its assistance with using the SSARR model and the PCRI for providing feedback on the design of the operational system.

\section{DESCRIPTION OF STUDY AREA AND DATA-COLLECTION NETWORK}

The study area is the Puyallup River Basin upstream of the streamgaging station Puyallup River at Puyallup (station number 12101500), located 6.6 miles upstream from the river's mouth at Commencement Bay. This area encompasses 948 square miles and ranges in elevation from near sea level to 14,410 feet at the peak of Mt. Rainier. The basin lies west of the Cascade Range and southeast of the City of Tacoma and constitutes most of eastern Pierce County and part of southeastern King County (fig. 1). Warm dry summers and cool wet winters are characteristic of the basin's climate. Storms, usually from the west or southwest, are typically large frontal storms of low intensity and long duration. Precipitation generally increases with elevation west of the Cascade divide, but is also influenced by storm tracks and local topography. The flood season coincides with the rainy season (table 1), generally from November to March.

The major streams that make up the Puyallup River System include the White River and its major tributary, the Greenwater River, which drain the northern and eastern part of the basin; the Carbon River and its major tributary, South Prairie Creek, which drain the central part of basin; and the main stem of the Puyallup River, which drains the southern part of the basin (fig. 1). Mud Mountain Dam, on the White River, is operated by the Army Corps of Engineers (USACOE) for flood control and forms Mud Mountain Lake, with a storage capacity of 106,000 acre-feet. Six miles downstream from Mud Mountain Dam at river mile 24.3, water is diverted from the White River by the White River Canal, which feeds Lake Tapps, and eventually is returned to the White River at river mile 3.6. Lake Tapps, operated by Puget Power for hydroelectricity, has a storage capacity of 46,600 acre-feet, and the canal has a capacity of about 2,000 cubic feet per second $\left(\mathrm{ft}^{3} / \mathrm{s}\right)$. On the Puyallup River, Puget Power diverts water up to $400 \mathrm{ft}^{3} / \mathrm{s}$ through a flume at river mile 41.8 to the Electron Powerhouse and returns the water to the river at river mile 31.2, 4.8 miles upstream of the Puyallup River near Orting stream gage (fig. 1). There is negligible water storage capacity at the Electron Powerhouse 


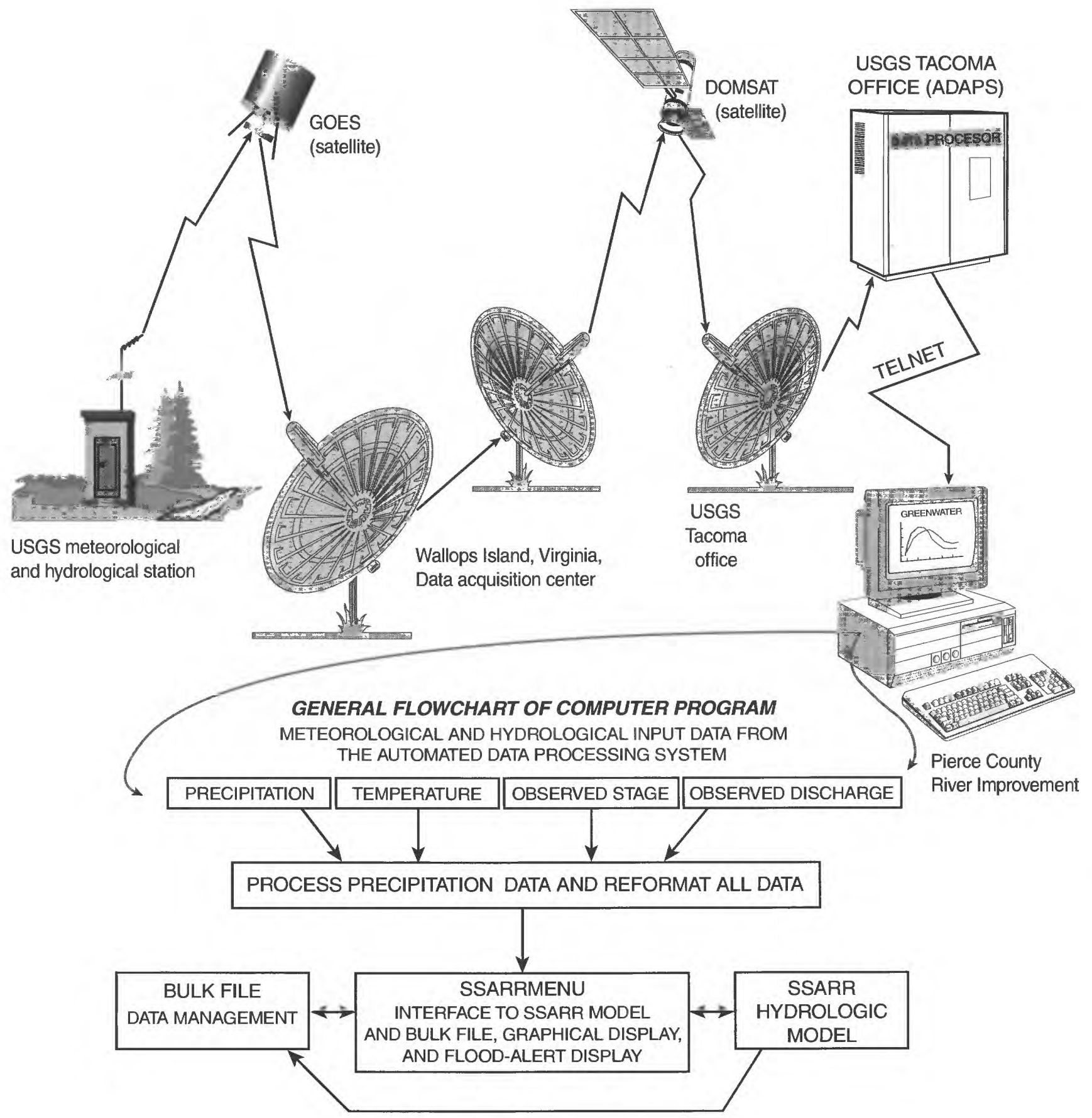

Figure 2. Generalized flowpath of hydrological and meteorological data from the gage sites to the Pierce County River Improvement office and within the computer for the Puyallup Flood Alert System. 
Table 1. Normal monthly and annual precipitation, base period 1961-90, for selected National Weather Service stations in or near the Puyallup River Basin, Washington (see figure 5 for station locations)

\begin{tabular}{lcccc}
\hline & \multicolumn{4}{c}{ Precipitation, in inches } \\
\cline { 2 - 5 } & $\begin{array}{l}\text { Rainier Paradise } \\
\text { RNGER, elevation }\end{array}$ & $\begin{array}{l}\text { Longmire Rainier } \\
\text { National Park } \\
\text { Service, elevation }\end{array}$ & $\begin{array}{l}\text { Mud Mountain, } \\
\text { elevation }\end{array}$ & $\begin{array}{l}\text { McMillin } \\
\text { Reservoir, } \\
\text { elevation }\end{array}$ \\
& $\begin{array}{l}\text { 5,427 feet } \\
\text { above sea level }\end{array}$ & $\begin{array}{l}\text { 2,762 feet } \\
\text { above sea level }\end{array}$ & $\begin{array}{l}1,308 \text { feet } \\
\text { above sea level }\end{array}$ & $\begin{array}{l}\text { 579 feet } \\
\text { above sea level }\end{array}$ \\
\hline October & 9.03 & 6.72 & 4.57 & 3.38 \\
November & 17.20 & 11.52 & 7.55 & 6.00 \\
December & 18.38 & 12.51 & 6.93 & 5.89 \\
January & 18.32 & 13.31 & 7.13 & 5.72 \\
February & 13.71 & 9.16 & 5.16 & 4.37 \\
March & 11.97 & 7.33 & 5.05 & 4.05 \\
April & 8.42 & 5.59 & 4.91 & 3.14 \\
May & 5.18 & 3.13 & 3.73 & 2.38 \\
June & 3.76 & 1.67 & 1.89 & 1.06 \\
July & 1.95 & 2.34 & 2.48 & 1.50 \\
August & 2.79 & 4.25 & 3.36 & 2.12 \\
September & 4.96 & 82.23 & 57.04 & 41.77 \\
Annual & 115.64 & & & \\
\hline
\end{tabular}

The land cover in the upper basin is mostly forests, and timber harvesting by clear-cutting is common. In the lower elevations the landscape varies from rural, low-density land uses such as dairy farming and residential to the high-density urbanized areas near Puyallup near the mouth of the river.

The data-collection network consists of 15 stream gages, 7 rain gages, 8 air-temperature sites, and 1 snow pillow (fig. 3). As a part of this study, the Buck Creek meteorological site was established; air-temperature probes and rain gages were added to the South Prairie Creek, White River Canal, and Greenwater stream gages; and the Greenwater stream gage was upgraded from a seasonal (June to October) to a year-round streamflow gage with satellite telemetry. Each of the streamflow gages is on a 15-minute recording cycle that transmits the data via satellites to the USGS office in Tacoma every four hours in a normal (non-flood) mode or every 15 minutes in an alert mode. Precipitation and temperature are measured either every 15 minutes or every hour and transmitted via satellite telemetry. Because only the Buck Creek and White River Canal precipitation gages are heated, data collected at the other sites while snow is falling are not considered reliable. An auxiliary meteorological site at the Nevan-McCullough Seed Orchard, established in 1995 and operated for the 1995 and 1996 water years, included two heated precipitation gages (one shielded and one not shielded), an air-temperature probe, and an anemometer (to record wind velocity and direction). Because this site does not have real-time telemetry, it is not used in the operational system.

\section{CONCEPTUAL MODEL OF FLOODING}

The conceptual model in this investigation is simply a collection of the important hydrological and meteorological factors related to the recent large flood events in the Puyallup River Basin. (The term "flooding," as used here and elsewhere in the report, refers to high flow discharges and high flow stages and not to areas inundated by floods.) The conceptual model is the framework for the numerical model selection and the focus of the calibration and validation efforts used in this investigation. The conceptual model is based on the largest floods since 1965 and selected observed meteorological data for representative stations. After data were reviewed and initial simulations were made, it was apparent that the distribution of water available for runoff (rain and snowmelt) is a chief factor in the conceptual model of flooding in the Puyallup River Basin. While accounting for soil moisture and its effect on runoff is an important factor in the conceptual model, precise understanding of many other runoff processes is less important. For example, the flow path that runoff takes to the stream channel, the influence on ground-water interaction, or the location in the soil profile where moisture is being stored needs little attention. Also, the data to describe such runoff characteristics or processes are generally not available. 


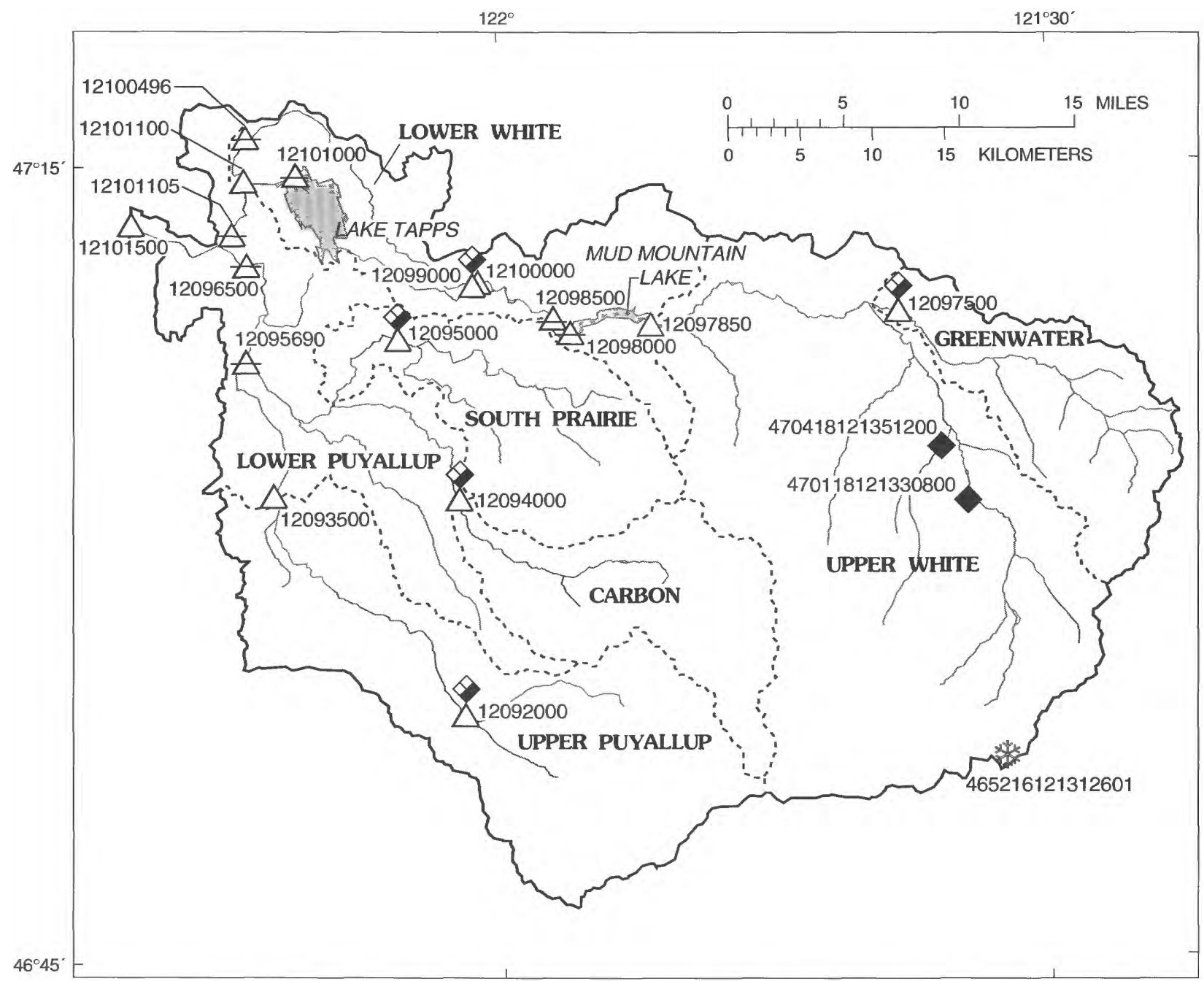

\section{EXPLANATION}

Puyallup River Basin boundary

CARBON ${ }^{-}$Subbasin boundary and name

$\triangle \quad$ Stream gage reporting stage and discharge

$\triangle \quad$ Stream gage reporting stage only

Snow pillow site

Meteorological site recording precipitation and temperature

Stream gage recording precipitation and temperature
USGS Station Number

12092000

12093500

12094000

12095000

12095600

12096500

12097500

12097850

12098000

12098500

12099000

12100000

12100496

12101000

12101100

12101105

12101500

470118121330800

465216121312601 470418121351200

\section{Station Name}

Puyallup River near Electron Puyallup River near Orting Carbon River near Fairfax South Prairie Creek at South Prairie Carbon River near Fairfax Puyallup River at Alderton Greenwater River at Greenwater White River below Clearwater River near Buckley

Mud Mountain Lake near Buckley

White River near Buckley

White River Canal at Buckley

White River at Buckley

White River near Auburn

Lake Tapps near Sumner

Lake Tapps Diversion near Dieringer White River at Williams Bridge at Sumner Puyallup River at Puyallup

Buck Creek Camp meterological site near Greenwater

Cayuse Pass snow course Nevan-McCullough Seed Orchard meteorological site near Greenwater

Figure 3. Streamflow and meteorological network of U.S. Geological Survey-operated gages in the Puyallup River Basin, Washington. 


\section{Flood History}

Several long-term stream gages in the basin provide a good history of floods on rivers in the Puyallup River Basin since the 1930's (table 2). Although Mud Mountain Dam has regulated flood flows on the White River and the lower Puyallup River since its completion in 1942, the 1934 peak flow, the largest recorded at the Puyallup River at Puyallup, was unregulated. The other stations listed in table 2 are all upstream of major regulation.

Other notable floods include the record 1978 peak flow in the Greenwater River, which was almost twice the discharge of the second largest peak flow-clearly a significantly large flood in the record. The 1996 peak flows, all during February 8-9, 1996, are ranked number one or two at all the stations listed in table 2 , and because they occurred during the model calibration and validation period of this study (water years 1994-97), they provided an excellent opportunity to calibrate the numerical model to a significantly large flood. If the November 28,1995 , peaks had not been exceeded by the February 1996 peak flows, they would have ranked in the 10 highest recorded annual peaks at all but the Puyallup River at Puyallup gage sites. On the other end of the scale, 1994 peak flows ranked last or near last for all the stations listed. Although the 1994 peak flows occurred during the model calibration and validation period, they do not provide useful data for testing the model and, therefore, were not used. The other floods during the data-collection period of this study lie in the midrange of the ranked floods.

\section{Meteorological Conditions Related to Flooding}

Comparing meteorological data associated with the largest recorded floods reveals some important aspects of flooding in the Puyallup River Basin (table 3). It is correct to assume that flooding is related to precipitation, but in the Puyallup River Basin the relation is not straightforward. As seen in table 3, precipitation amounts do not correlate well with the peak discharges. For the eight largest floods, 1-day precipitation at the Rainier Paradise RNGER station varied from 2.60 inches to 7.76 inches, and 5-day precipitation varied from 6.87 to 17.53 inches. For reference, the precipitation total with a 10-year, 24-hour precipitation frequency for this station is about 6.2 inches (U.S. Department of Commerce, 1973). (The 10-year, 24-hour precipitation frequency is the average amount of rainfall over a 24-hour period that is exceeded on average once every 10 years.)
The most likely explanation for this lack of a strong correlation between rainfall total and peak discharge is that the runoff during floods with low precipitation totals was augmented with snowmelt. In basins of western Oregon (similar to the Puyallup River Basin), a transient snow zone, the zone of transition between precipitation as rain and precipitation as snow, is from 1,150 to 3,610 feet (350 to 1,100 meters) above sea level (Harr, 1986 . By this definition, the transient snow zone of the Puyallup River Basin takes up 38.8 percent of the drainage area. Therefore, depending on the extent of snow in the basin and the freezing levels during a storm, rain-on-snow events in the Puyallup River Basin may contribute significantly to runoff from snowmelt. Floods with relatively low precipitation amounts at the Paradise (elevation 5,427 feet) and Longmire (elevation 2,762 feet) stations generally had high snowmelt index values and relatively high temperatures (table 3 ). (The snowmelt index described in table 3 is a simple indicator of snowmelt during storms based on reported observed snow on the ground at NWS stations). By contrast, the lower elevation stations Mud Mountain Dam (elevation 1,308 feet) and McMillin Reservoir (elevation 579 feet) did not show any addition of snowmelt to runoff (index $=0$ ), although the available data are sparse. Maximum surface air tomperatures were above freezing for all the floods (table 3 ). The 1996 flood, the largest flood in table 2, had high sn owmelt, temperatures, and precipitation totals-a sure recipe for big floods.

Schermerhorn (1967, p.707) stated, "The [spatial] variation in annual precipitation in western Oregen and Washington is greater than anywhere else in the contiguous 48 states," and, indeed, in the Puyallup River Basin large variations in precipitation often occur over short distances due primarily to differences in elevation. Precipitation normally increases with increased elevation, as can be seen, with few exceptions, by relating storm precipitation totals and Normal Annual Precipitation ("NAP" is the term used by the National Weather Service in its climatological data reports; NAP is the same as the mean annual precipitation over a specified period or "base periad") to elevations for the four stations in table 3. The NAP at McMillin Reservoir (elevation 579 feet) is only 36 percent of NAP at Rainier Paradise (elevation 5,427 feet) 35 miles away. While this is usually true for annual totals, individual storm precipitation totals at lower elev'tions may exceed those at higher elevations due to short-term variations in atmospheric circulation patterns, winds, and temperatures in combination with the topography of the basin. 
Table 2. Ten largest annual peak discharges (ranks 1 through 10) for selected stations in the Puyallup River Basin, Washington, and the annual peak flows* used during the model calibration and validation period of this study (1994-97 water years)

[USGS, U.S. Geological Survey; M/D, month/day; $\mathrm{ft}^{3} / \mathrm{s}$, cubic feet per second]

\begin{tabular}{|c|c|c|c|c|c|c|c|c|c|c|c|}
\hline \multicolumn{4}{|c|}{$\begin{array}{l}\text { Puyallup River at Puyallup } \\
\text { USGS Station Number } 12101500 \\
\text { Record: } 1914-97 \\
83 \text { years of annual peak-flow data }\end{array}$} & \multicolumn{4}{|c|}{$\begin{array}{l}\text { Greenwater River at Greenwater } \\
\text { USGS Station Number } 12097500 \\
\text { Record: } 1912,1930-78,1993-97 \\
53 \text { years of annual peak-flow data }\end{array}$} & \multicolumn{4}{|c|}{$\begin{array}{l}\text { South Prairie Creek at South Prairie } \\
\text { USGS Station Number } 12095000 \\
\text { Record: } 1950-79,1988-97 \\
40 \text { years of annual peak-flow' data }\end{array}$} \\
\hline Rank & $\begin{array}{l}\text { Water } \\
\text { year }\end{array}$ & $\begin{array}{l}\text { Date } \\
(\mathrm{M} / \mathrm{D})\end{array}$ & $\begin{array}{l}\text { Discharge } \\
\left(\mathrm{ft}^{3} / \mathrm{s}\right)\end{array}$ & Rank & $\begin{array}{l}\text { Water } \\
\text { year }\end{array}$ & $\begin{array}{l}\text { Date } \\
\text { (M/D) }\end{array}$ & $\begin{array}{l}\text { Discharge } \\
\left(\mathrm{ft}^{3} / \mathrm{s}\right)\end{array}$ & Rank & $\begin{array}{l}\text { Water } \\
\text { year }\end{array}$ & $\begin{array}{l}\text { Date } \\
\text { (M/D) }\end{array}$ & $\begin{array}{l}\text { Discharge } \\
\left(\mathrm{ft}^{3} / s\right)\end{array}$ \\
\hline 1 & 1934 & $12 / 10$ & 57,000 & 1 & 1978 & $12 / 02$ & 10,500 & 1 & 1996 & $02 / 08$ & $* 8,170$ \\
\hline 2 & 1996 & $02 / 09$ & $* 46,700$ & 2 & 1996 & $02 / 08$ & $* 5,900$ & 2 & 1956 & $12 / 11$ & 6,850 \\
\hline 3 & 1990 & $01 / 09$ & 44,800 & 3 & 1960 & $11 / 22$ & 5,360 & 3 & 1965 & $01 / 29$ & 6,400 \\
\hline 4 & 1987 & $11 / 24$ & 43,800 & 4 & 1965 & $01 / 29$ & 5,090 & 4 & 1990 & $01 / 09$ & 5,030 \\
\hline 5 & 1991 & $11 / 24$ & 41,900 & 5 & 1947 & $12 / 11$ & 5,000 & 5 & 1954 & $12 / 09$ & 5,470 \\
\hline 6 & 1965 & $01 / 29$ & 41,500 & 6 & 1934 & $12 / 09$ & 4,140 & 6 & 1991 & $02 / 19$ & 5,390 \\
\hline 7 & 1978 & $12 / 02$ & 40,600 & 7 & 1976 & $12 / 02$ & 4,140 & 7 & 1975 & $01 / 18$ & 5,020 \\
\hline 8 & 1918 & $12 / 18$ & 40,500 & 8 & 1912 & $11 / 19$ & 2,800 & 8 & 1976 & $12 / 02$ & 4,380 \\
\hline 9 & 1935 & $10 / 25$ & 39,500 & 9 & 1971 & $01 / 31$ & 2,260 & 9 & 1974 & $01 / 16$ & $4, \therefore 10$ \\
\hline 10 & 1933 & $11 / 13$ & 37,800 & 10 & 1956 & $12 / 12$ & 2,230 & 10 & 1960 & $11 / 20$ & 3,900 \\
\hline 35 & 1997 & $01 / 01$ & $* 22,800$ & 21 & 1997 & 01/01 & $* 1,510$ & 14 & 1997 & $01 / 01$ & $* 3,4,90$ \\
\hline 49 & 1995 & $02 / 19$ & $* 19,200$ & 27 & 1995 & $02 / 20$ & $* 1,330$ & 23 & 1995 & $02 / 19$ & $* 2,690$ \\
\hline 79 & 1994 & $03 / 03$ & $* 9,040$ & 54 & 1994 & $01 / 14$ & $* 574$ & 36 & 1994 & $03 / 03$ & $* 1,500$ \\
\hline \multicolumn{4}{|c|}{$\begin{array}{l}\text { Carbon River near Fairfax } \\
\text { USGS Station Number } 12094000 \\
\text { Record: } 1930-78,1991-97 \\
56 \text { years of annual peak-flow data }\end{array}$} & \multicolumn{4}{|c|}{$\begin{array}{l}\text { Puyallup River near Orting } \\
\text { USGS Station Number } 12093500 \\
\text { Record: } 1932-97 \\
66 \text { years of annual peak-flow data }\end{array}$} & & & & \\
\hline Rank & $\begin{array}{l}\text { Water } \\
\text { year }\end{array}$ & $\begin{array}{l}\text { Date } \\
\text { (M/D) }\end{array}$ & $\begin{array}{l}\text { Discharge } \\
\left(\mathrm{ft}^{3} / \mathrm{s}\right)\end{array}$ & Rank & $\begin{array}{l}\text { Water } \\
\text { year }\end{array}$ & $\begin{array}{l}\text { Date } \\
(\mathrm{M} / \mathrm{D})\end{array}$ & $\begin{array}{l}\text { Discharge } \\
\left(\mathrm{ft}^{3} / \mathrm{s}\right)\end{array}$ & & & & \\
\hline 1 & 1991 & $11 / 24$ & 13,000 & 1 & 1996 & $02 / 08$ & $* 18,300$ & & & & \\
\hline 2 & 1996 & $02 / 08$ & $* 12,000$ & 2 & 1963 & $11 / 20$ & 15,300 & & & & \\
\hline 3 & 1934 & $12 / 09$ & 11,000 & 3 & 1960 & $11 / 22$ & 12,900 & & & & \\
\hline 4 & 1978 & $12 / 01$ & 10,000 & 4 & 1934 & $12 / 10$ & 12,800 & & & & \\
\hline 5 & 1960 & $11 / 23$ & 9,970 & 5 & 1965 & $01 / 29$ & 12,200 & & & & \\
\hline 6 & 1968 & $12 / 25$ & 7,480 & 6 & 1956 & $12 / 11$ & 12,100 & & & & \\
\hline 7 & 1976 & $12 / 01$ & 7,460 & 7 & 1978 & $12 / 02$ & 12,100 & & & & \\
\hline 8 & 1975 & $01 / 18$ & 7,320 & 8 & 1933 & $11 / 13$ & 11,800 & & & & \\
\hline 9 & 1974 & $01 / 15$ & 7,180 & 9 & 1990 & $01 / 09$ & 11,600 & & & & \\
\hline 10 & 1933 & $11 / 13$ & 7,100 & 10 & 1947 & $12 / 11$ & 11,200 & & & & \\
\hline 23 & 1995 & $10 / 31$ & $* 4,900$ & 21 & 1997 & $01 / 01$ & $* 8,460$ & & & & \\
\hline 29 & 1997 & $11 / 27$ & $* 4,480$ & 36 & 1995 & $10 / 31$ & $* 5,890$ & & & & \\
\hline 56 & 1994 & $03 / 03$ & $* 1,100$ & 66 & 1994 & $03 / 03$ & $* 1,830$ & & & & \\
\hline
\end{tabular}




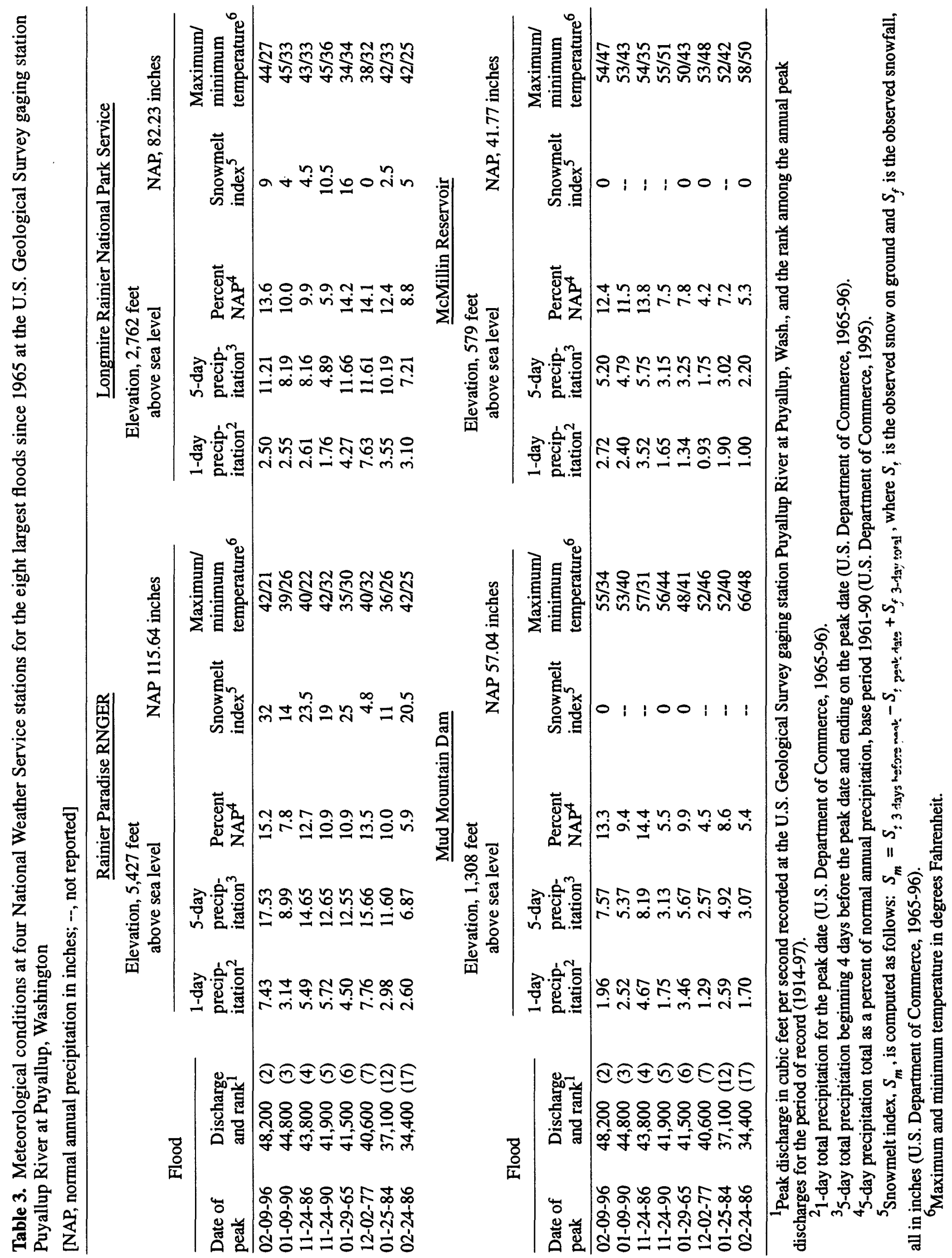


Several floods listed in table 3 can be characterized as high-elevation or low-elevation precipitation events. The December 1977 flood could be characterized as a high-elevation precipitation event because the 5-day precipitation as a percentage of NAP is greater at the two higher elevation stations in table 3 (13.5 and 14.1 percent) than at the two lower elevation stations (4.5 and 4.2 percent). In contrast, the November 1986 flood could be called a low-elevation precipitation event because the NAP percentages for the 5-day precipitation totals for the two lower elevation stations are higher than any others listed, while the NAP percentages for the two high-elevation stations are ranked among the lowest two peaks listed.
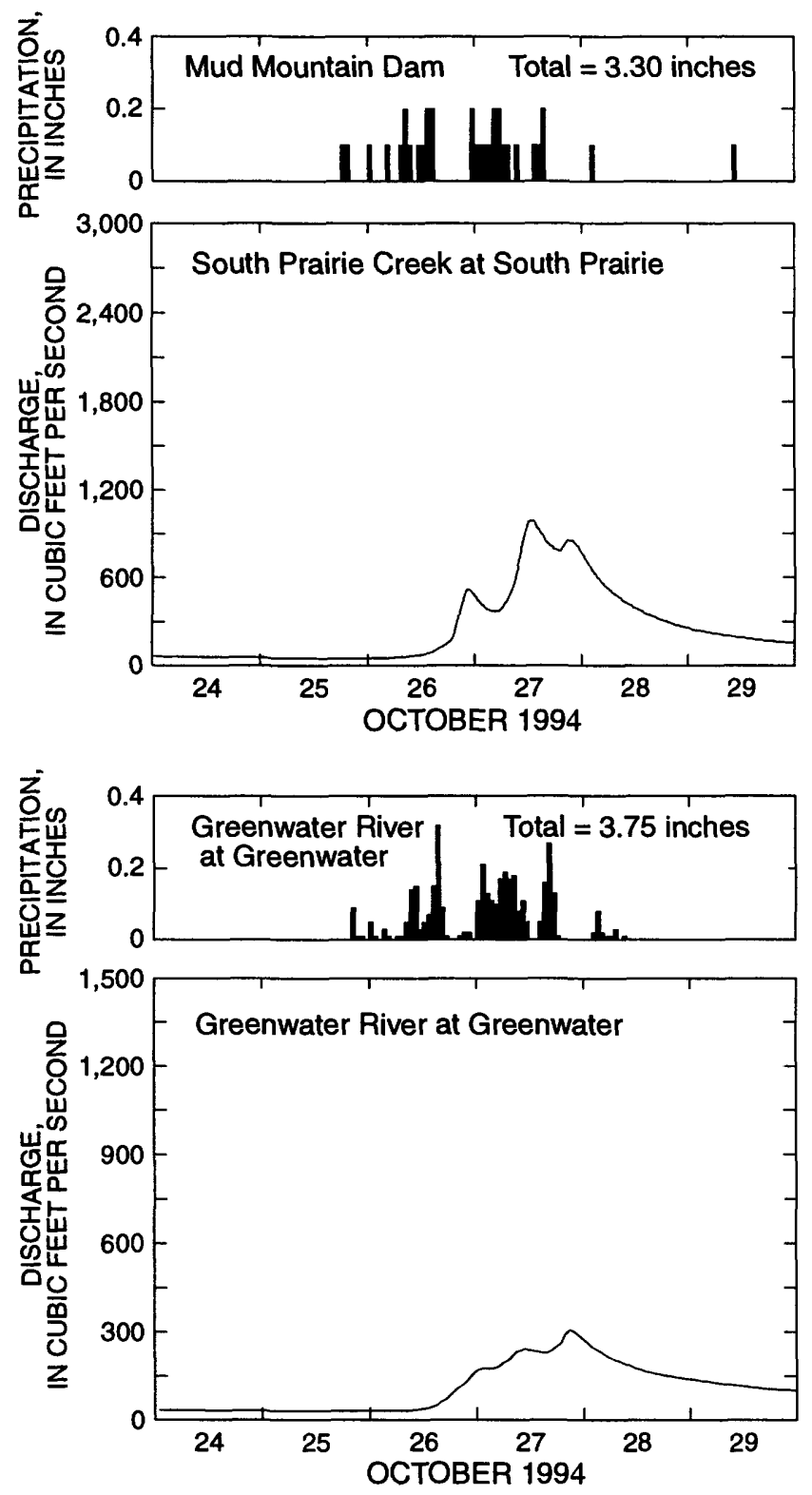

The dates of the annual peak discharges in the Puyallup River Basin define a relatively short season from mid-November to early March for large floods (table 2). This is the season of the heaviest rains (table 1), and although November is a month of heavy rain, there is a lag time on the order of several weeks to months befo"e major flooding normally occurs. The rains through early' November must saturate the relatively dry soils before a large enough portion of the rainfall becomes runoff. This phenomenon can be seen by comparing runoff from two storms in October and December 1994 (fig. 4) with similar precipitation totals and intensities and similar above-freezing temperatures (no snowfall was recorded at the Rainier Longmire NWS weather station during either storm).
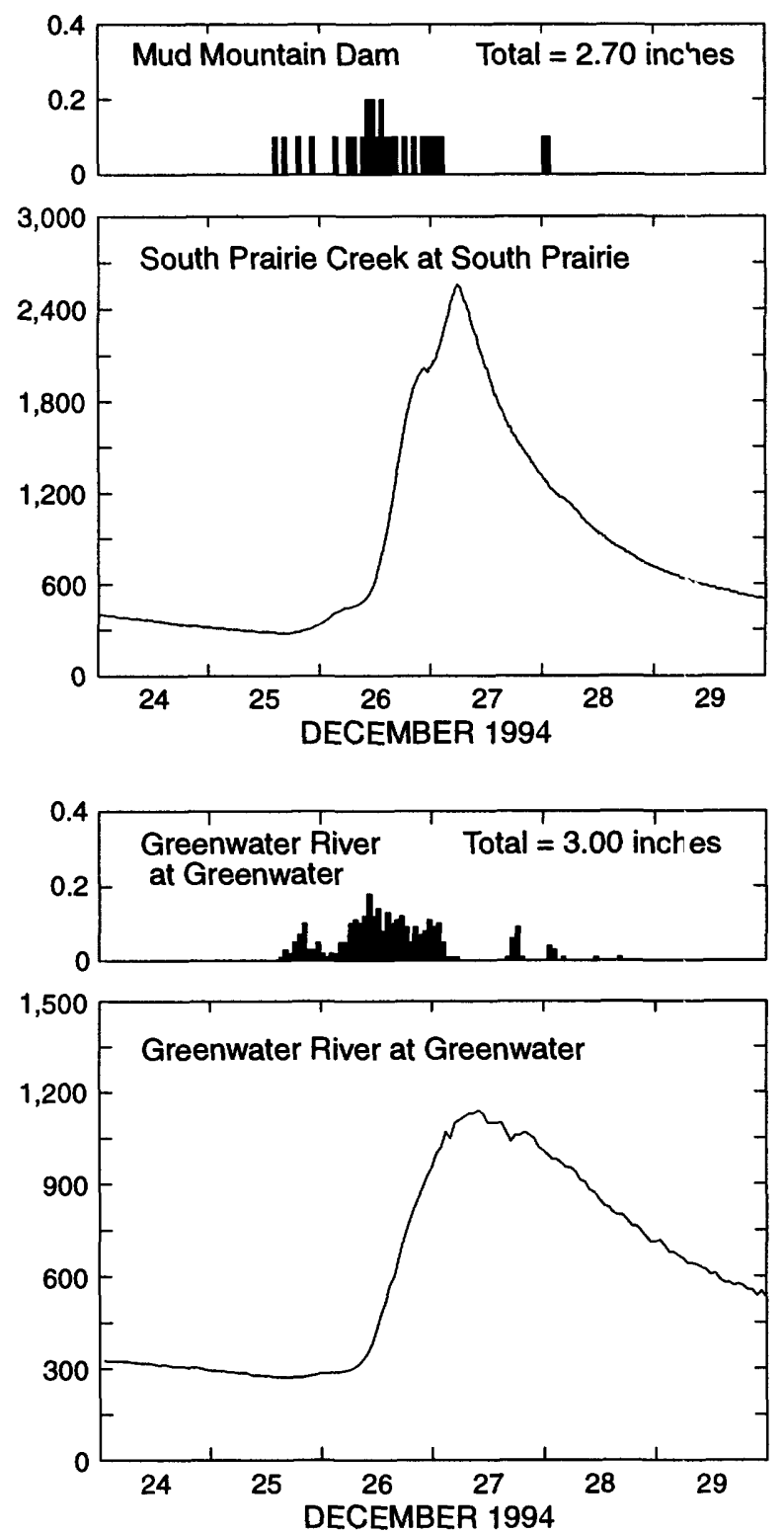

Figure 4. Comparison of runoff response to precipitation between an early fall and early winter storm at two gaging stations in the Puyallup River Basin, Washington. 
Although the December storm had 18 to 20 percent less precipitation than the October storm, the peak discharge was 2.6 to 3.7 times as large. Much of the rainfall in the October storm most likely infiltrated the ground and was stored in the soil, while during the December storm (after two more months of rain had saturated the soil) a larger fraction of the rainfall became runoff. Although snow is often present in the midelevation in the spring and perennial in the higher elevations, flooding due strictly to snowmelt has rarely produced major flooding, and as the chance for heavy rains diminishes in the spring, so does the chance for heavy flooding.

\section{Generalizations about Flooding in the Puyallup River Basin}

An examination of the meteorological conditions associated with large floods in the Puyallup River Basin has identified five important factors that define the basis for the conceptual model of how major floods are generated in the Puyallup River Basin:

1. Topography has a strong influence on precipitation; precipitation generally increasing as elevation increases.

2. Spatial patterns of precipitation totals of individual storms may vary considerably from the pattern defined by annual totals.

3. Flooding is primarily associated with storms bringing heavy rain to the basin, but snowmelt is an important contribution to flooding.

4. The extent of snow cover and the freezing level during a storm are important factors in the snowmelt contributions to runoff.

5. Most of the soil moisture storage capacity must be filled before heavy flooding can begin.

\section{DESCRIPTION OF THE NUMERICAL MODEL}

The Integrated-Snowband version of the SSARR model (U.S. Army Corps of Engineers, 1991) was used in this investigation for simulating river discharges and stages because of its ability to make real-time forecasts, its compatibility with the personal computers (PC's) in the PCRI computer system, its longtime use in the Pacific Northwest, its ability to simulate floods according to the conceptual model for flooding in the Puyallup River Basin described earlier, and its ability to route natural and regu- lated flows through river channels and reservoirs. The SSARR model was developed by the U.S. Army Corps of Engineers (USACOE) for managing the Columbia River and has been used by the Northwest River Forecast Center of the NWS in Portland, Oreg., to make flood forecasts on many of the major rivers in the Pacific Northwest. The following is a brief description of the model, and the reader is referred to the SSARR user's manual (U.S. Army Corps of Engineers, 1991) for complete details of 1 ow the model works.

\section{The SSARR Model}

In the SSARR model, the modeled basin is dirided into subbasins that drain to a network of storm reaches and reservoirs. The model simulates runoff by routing available water from rainfall and snowmelt from subbarins to streams and routes streamflow through the stream network. The model's characteristics, which are input data to the model that govern the simulation of runoff and routing, include such items as subbasin area, elevation, em irical coefficients that control infiltration, and tables relating stream channel or reservoir storage to outflow.

The SSARR model can store information aborit watershed and channel conditions, such as soil moisture and stream discharge, at the end of a simulation ard start another simulation using these stored or modified conditions as initial conditions, thus allowing easy incorporation of real-time data as it is retrieved to make imfroved forecast results. The model also can adjust the sim'vlated watershed runoff automatically to mimic the observed record by adjusting the inputs of precipitation, lapse rates, or temperature until the simulated record matches the observed record within specified tolerances.

The SSARR model also is appropriate for simulating peak discharges for the Puyallup River Basin because of (1) its continuous modeling in time (as opposed to event-based models) that accounts for antecedent soil moisture conditions and snow accumulation, (2) it temperature-index snowmelt algorithm (as opposed to energy-balance snowpack models that require more data input than is generally available), (3) its division of the watershed into elevation zones (snowbands) with corresponding division of precipitation (as rain or snow) and temperature according to defined precipitation-elevation curves and lapse rates, and (4) its distribution of w'ater available for runoff into surface and subsurface flc w paths as a function of soil moisture. A simple storage-routing equation computes the lengths of time (lag time) for water available for runoff to reach the stream for each of the flow 
components. The lag time defines the shape of the simulated hydrograph, which is adjusted through calibration to mimic the shape of the observed hydrograph. The SSARR model also simulates such other important hydrologic processes as interception, evapotranspiration, ripening of the snow pack, and groundmelt of the snow pack. The hydrologic parameters that govern the simulation of the hydrologic processes are the same throughout a subbasin, although precipitation and temperature inputs are adjusted differently for each snowband by user-defined precipitation-elevation relations and temperature lapse rates.

The NWS Northwest River Forecast Center has used a depletion version of the SSARR model to make routine flood forecasts on the Puyallup River. Many of the NWS depletion version's runoff parameters and flow-routing tables (outflow as a function of storage or stage) were used to construct the preliminary snowband SSARR model (a numerical model with uncalibrated parameters) for this investigation. The NWS depletion version was not used directly for several reasons (which are discussed further in the next paragraph): (1) The current network of precipitation and temperature gages within the basin provides a more accurate model than the network of region-wide gages used in the NWS model. (2) Many stations for which PCRI was interested in estimating discharge or stage during flood events are not represented in the NWS model. (3) The snowband version can continuously track current snow-water equivalent (SWE) in the basin's snowpack. (4) And the Columbia River Operation Hydromet Management System (CROHMS) network of gages used by the NWS is not generally available to county agencies, nor is it compatible with the PC version of the SSARR model.

The NWS SSARR depletion model used four subbasins, a 6-hour time step, one temperature station, and a set of regional precipitation stations, all outside the Puyallup River Basin. This investigation uses the SSARR Integrated Snowband model, with seven subbasins and four temperature stations and six precipitation stations located within the basin. The snowband model uses a 1-hour time step during storms (storm mode), and a 6-hour time step at other times (backup or nonstorm mode). However, when the model is used to forecast discharges, 6-hour time steps are used because forecasted temperature and precipitation are available only for 6-hour time steps. The 1-hour time step provides more definition of the storm hydrograph than a 6-hour time step, and it provides more flexibility to stop the model at specific times in anticipation of a subsequent model run. Although the snowband model used for this investigation uses considerably more input data than does the NWS model (the current
USGS-operated gage network of local meteorological gages instead of regional NWS gages) and greatly' enhances the detail of the simulation model (seven subbasins instead of the four used by the NWS, and a 1-hour time step instead of a 6-hour time step), there is tr ? disadvantage that the calibration and validation period is limited to the 1994-97 water years - the period during which the current gage network has existed.

\section{Subdivision of the Puyallup River Basi` into Subbasins and Elevation Zones}

In the snowband model, the Puyallup River Basin is subdivided into 7 subbasins and 13 elevation zones (fig. 3 and table 4). Elevation zones are synonymous with the SSARR model term "snowbands." The subbasins are based on the topographic divides and locations of river confluences and stream gages. For example, the South Prairie subbasin is defined as the drainage basin unstream of the mouth of South Prairie Creek at the conflue ace with the Carbon River. Even though the stream gage South Prairie Creek at South Prairie (USGS station number 12095000 ) is located 5.9 miles upstream of the cc nfluence, it is still representative of the outflow at the mouth because there are no major inflows between the gage and the mouth.

The Carbon subbasin is defined as the drainage basin upstream of the gage on the Carbon River near Fcirfax (fig. 3) because this gage lies 16.1 miles upstream of the mouth and there are several significant inflows between the gage and the mouth. The upper White subbasin, the largest subbasin, is defined as the drainage basin I'stream of the gage on the White River below Clearwater River near Buckley (fig. 3), excluding the Greenwater F : ver drainage (the Greenwater subbasin). The upper White subbasin, which is more than twice as large as the second largest subbasin, is not subdivided into smaller urits because there are no upstream gages at which to compare simulated runoff with observed runoff.

The elevation zones are subareas in each subt asin that encompass defined elevation boundaries. In the F ryallup River Basin model, the area between elevations 0 to 5,000 feet above sea level is divided into 10 zones equally spaced vertically at 500 -foot intervals. The next zone is from 5,000 to 6,000 feet elevation; the next is from 6,000 to 8,000 feet elevation; and the last zone is everything above 8,000 feet elevation. The "contour interval " of the elevation zones were configured in this manner tc make the area within each zone approximately equal. The elevation zones were delineated using a digital elevatic $n$ model 


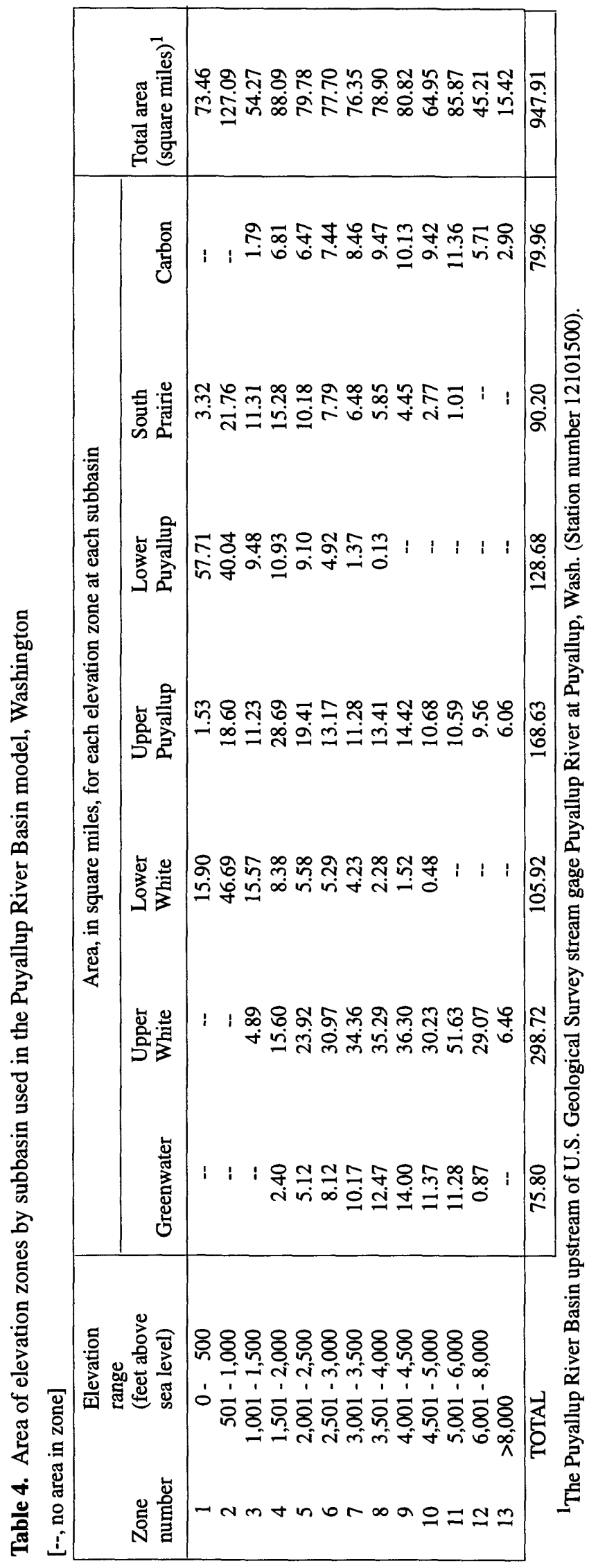

(DEM) of regularly spaced elevation values with a 30-meter (98.4-foot) grid-cell resolution (Washington Department of National Resources, 1994) derive.d from 1:24,000 scaled topographic maps (U.S. Geolog:cal Survey, 1987). Geographic Information System (GIS) software was used to slice the individual subbasins into the 13 zones and calculate the areas. The elevation boundaries and the amount of area for each zone were coded into the Puyallup River Basin model to define the snowbands for each subbasin. The model uses this information to adjust the meteorological inputs (precipitation ard temperature) to the midpoint elevation for each snowband and compute total volumes of runoff based on the area in each zone.

\section{Computation of Subbasin Precipitation}

Necessary input to the SSARR model inclurles a time series (a series of data values ordered in time) of precipitation associated with each subbasin. Since the p-ecipitation record at a gage generally does not represent the average precipitation for a basin, a weighting fartor is used to adjust the precipitation inputs. Althougl the model can adjust the input precipitation for each subbasin, for this investigation a separate time series for each subbasin was computed. The individual precipitation time series for each subbasin, $P_{\text {sub }}$, was calculated as a weighted average of two observed precipitation records:

$$
P_{s u b}=\frac{P_{s t a 1}\left(\frac{N A P_{s u b}}{N A P_{s t a 1}}\right)+P_{s t a 2}\left(\frac{N A P_{s t b}}{N A P_{s t a 2}}\right)}{2}
$$

where

$$
\begin{array}{cl}
p_{\text {sta } 1} \text { and } P_{\text {sta } 2} \begin{array}{l}
\text { are the recorded } \\
\text { precipitations at gaging } \\
\text { stations 1 and 2, } \\
\text { respectively; }
\end{array} \\
N A P_{\text {sub }} & \begin{array}{l}
\text { is the normal annual } \\
\text { precipitation for th? } \\
\text { subbasin; and }
\end{array} \\
N A P_{\text {sta } 1} \text { and } N A P_{\text {sta } 2} & \begin{array}{l}
\text { are the normal ann"al } \\
\text { precipitation for stations 1 } \\
\text { and 2, respectively. }
\end{array}
\end{array}
$$

After all the gage records were reviewed fo- erroneous or missing data, the two gages within or nearest to each subbasin that had complete and accurate d $\tau^{+}$a for the period of a particular simulation were selected f "om the six available real-time USGS-operated rain gager. Table 5 shows the matrix used to select the precipitation record and the NAP values used in equation 1. 
Table 5. Priority matrix for selecting two rain-gage records and normal annual precipitation used to compute a subbasin precipitation record, Puyallup River Basin, Washington

Priority Matrix

The first two rain gages listed in the rows below are selected for each subbasin. If a rain-gage record is determined to have missing or bad values, the next rain gage is selected.

\begin{tabular}{lllllll}
\hline Subbasin & \multicolumn{5}{c}{ Rain gages in order of priority for selection } \\
\cline { 3 - 6 } Greenwater & Greenwater & Buck Creek & Carbon & White River Canal & South Prairie & Electron \\
Upper White & Buck Creek & Greenwater & Carbon & White River Canal & South Prairie & Electronn \\
Lower White & White River. Canal & South Prairie & Greenwater & Buck Creek & Carbon & Electron \\
South Prairie & South Prairie & Carbon & Electron & Carbon & Buck Creek & Greenvvater \\
Upper Puyallup & Electron & Carbon & South Prairie & White River Canal & Buck Creek & Green'vater \\
Lower Puyallup & South Prairie & White River Canal & Carbon & Electron & Greenwater & Buck Creek \\
Carbon & Carbon & Electron & South Prairie & White River Canal & Buck Creek & Greenwater
\end{tabular}

Normal annual precipitation (NAP), in inches, for subbasins and rain gages, base period 1930-57

\begin{tabular}{|c|c|c|c|}
\hline Subbasin & NAP & Rain gages & NAP \\
\hline Greenwater & 90.69 & Greenwater & 56.54 \\
\hline Upper White & 79.43 & Buck Creek & 60.00 \\
\hline Lower White & 54.47 & Carbon & 59.55 \\
\hline South Prairie & 60.89 & White River Canal & 48.14 \\
\hline Upper Puyallup & 83.17 & South Prairie & 43.49 \\
\hline Lower Puyallup & 47.40 & Electron & 66.25 \\
\hline Carbon & 90.47 & & \\
\hline
\end{tabular}

The subbasin NAP values were based on an isohyetal map of mean annual precipitation for the State of Washington (Soil Conservation Service, 1965). The isohyets were digitized and overlaid on the subbasin boundaries to compute the subbasin NAP (fig. 5).

\section{Adjusting Meteorological Data Inputs for Elevation}

After time series of subbasin precipitation were computed from station precipitation, the values were adjusted for midpoint elevations of each snowband within the subbasin. In a similar manner, time series of temperature values at specific stations were adjusted by lapse rates to midpoint elevations of subbasin snowbands.

As discussed earlier, precipitation generally increases as elevation increases, but significant error would result if a single linear equation were used to represent the elevation-precipitation relation for the entire Puyallup River Basin. Figure 6 shows the relation defined for the Puyallup River Basin as a whole and individually for each subbasin as calculated from the isohyetal map shown on figure 5. Local topography can cause the relations to vary considerably from subbasin to subbasin. Several north-south ridges in the center of the Puyallup River Basin tend to create rain shadows, resulting in les? than basin-average precipitation east of the ridges. For example, the north-south trending Dalles Ridge defines the western drainage divide of the upper Greenwater s:bbasin, resulting in a relation of decreased precipitation w'ith increasing elevation above 5,000 feet. Data point- defining each subbasin's unique relation between precinitation and elevation were coded into the subbasin's fixed model characteristics (ELP tables) and applied during every time step to adjust the precipitation inputs for each snowband.

To reduce the amount of data input, only four of the seven real-time temperature stations (fig. 3) (the Cayuse Pass snow pillow site records temperature) were r'sed in the model. The three stations not used-Carbon Piver near Fairfax, White River Canal, and Greenwater River at Greenwater-were represented by nearby stations Buck Creek Camp and South Prairie Creek. The data for the four stations were applied to individual snowt ands during model runs and used to compute a time series of temperature lapse rates. The lapse rates, in units of degrees Fahrenheit for each 1,000-foot range in e'evation, 


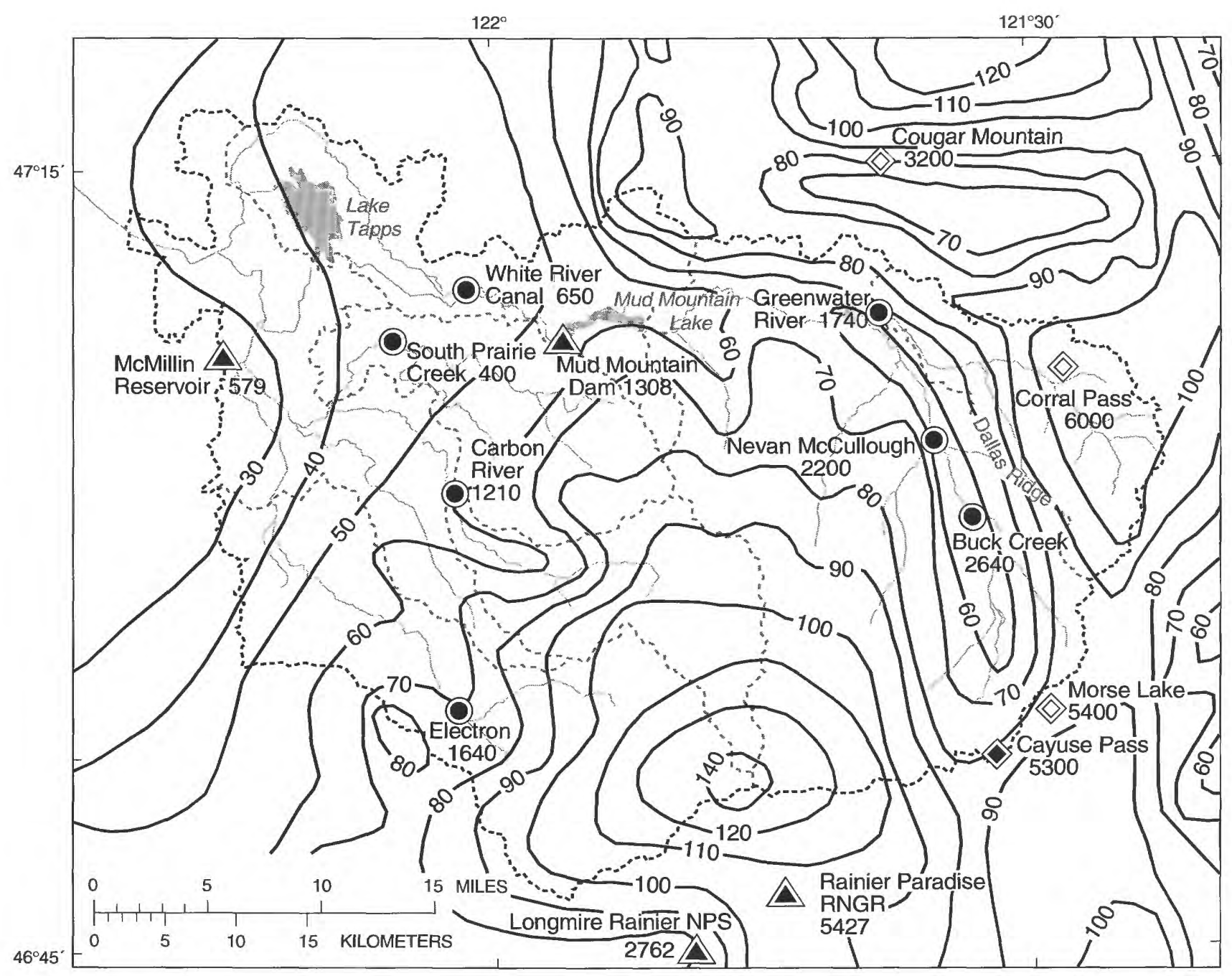

\section{EXPLANATION}

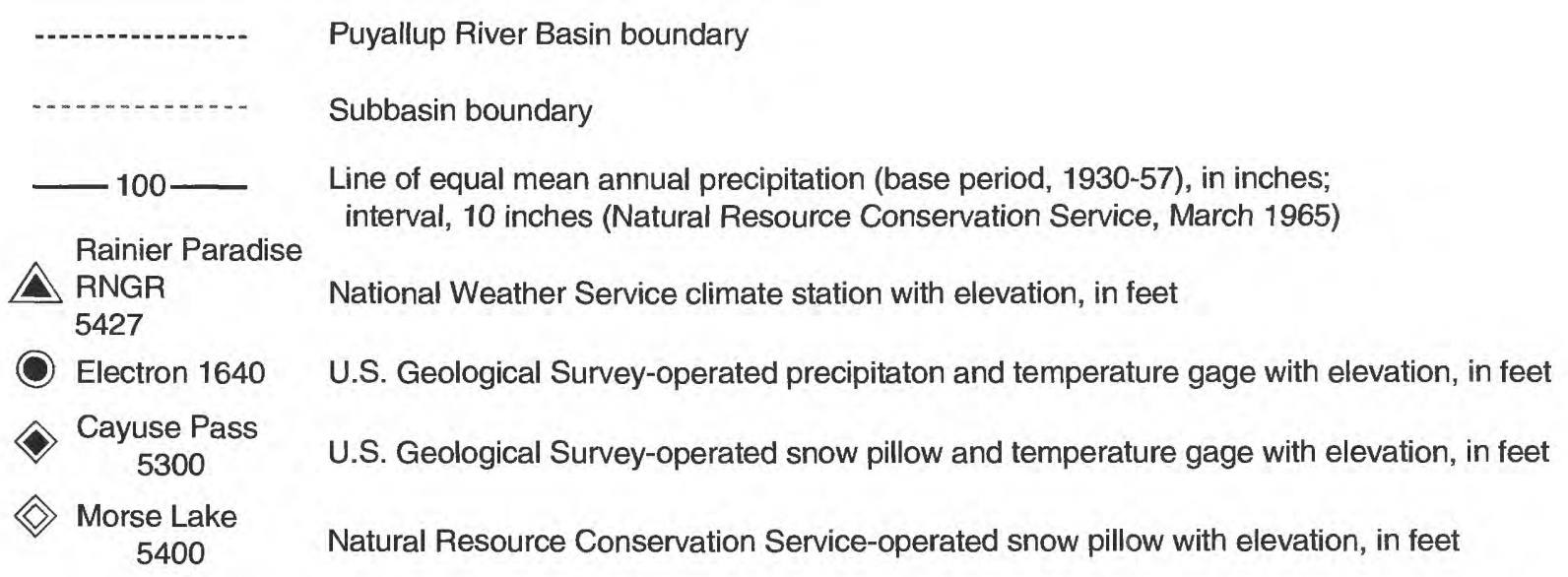

Figure 5. Weather stations and mean annual precipitation in the Puyallup River Basin, Washington. 


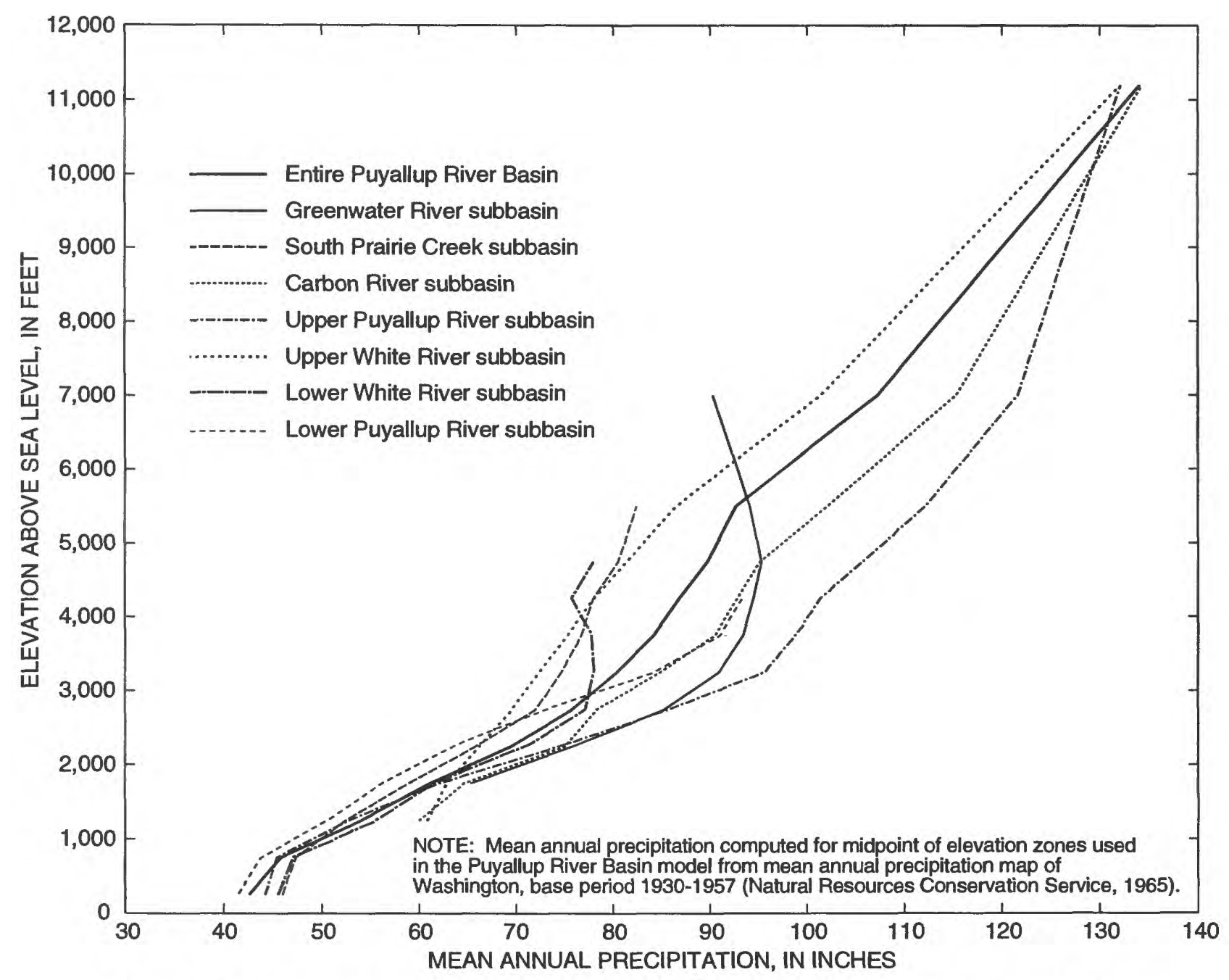

Figure 6. Mean annual precipitation as a function of elevation in the Puyallup River Basin and subbasins, Washington.

adjusted the station temperature values recorded at known elevations to the midpoint elevations of each snowband. Depending on the weather conditions, the lapse rate varied across the basin. If a temperature record for a specific time period contained bad or missing data, it was eliminated from the computations for that model run. A minimum of one good temperature record was needed to make a model run, and a minimum of two good temperature records was needed to compute a time series of lapse rates; otherwise, the default lapse rate value was used. Table 6 shows the priority matrix for determining which temperature records were selected for each subbasin.

Often a precipitation record was unusable for a particular model run because of missing or questionable data, and less often a temperature record was unusable. When this happened, the priority matrixes (table 5 and 6 ) were used to compute estimates of meteorological inputs for each subbasin. Although model results would be different if all the records were available, it is typical of actual real-time operation of the model.

\section{Runoff Simulation}

The hydrologic parameters that govern the simulation of runoff of rain and snowmelt from each subbasin in the snowband version of the model were originally taken from the depletion version of the SSARR model used by the NWS Northwest River Forecast Center for real-time flood forecasting for the Puyallup River Basin (Chuck Orwig, Northwest River Forecast Center, National Weather Service, written commun., 1993). In the snowband version of the model, the South Prairie and Carbon subbasins 
were initially assigned the same set of parameters as the Carbon subbasin in the NWS model; the Greenwater and upper White subbasins were assigned the same parameters as the NWS's Mud Mountain inflow subbasin; the lower White and lower Puyallup subbasins were assigned the same parameters as the NWS's Puyallup local subbasin; and the upper Puyallup subbasin was assigned the same parameters as the NWS's Orting subbasin. Values for these hydrologic parameters were changed slightly during calibration, which used data from the current network of USGS-operated precipitation stations for water years 1994-97. A listing of the final characteristics file, which contains the parameter values, is provided in the appendix of this report.
A flow chart of the computations for simulating runoff from individual snowbands by the SSARR Integrated Snowband model is shown on figure 7 . Table 7 defines the parameters, tables, and indexes found in the characteristics file and shown in the flow chart. Runoff simulation from a snowband can be broadly grouped into three parts: (1) simulating snow accumulation and melt; (2) partitioning moisture input among surface, subsurface, and baseflow components of flow; and (3) routing runoff in separate flow paths. These are discussed briefly in the following sections.

Table 6. Priority matrixes for selecting a single temperature record and a pair of temperature records to compute subbasin snowband temperature and subbasin temperature lapse rates, Puyallup River Basin, Washington

\section{Snowband-temperature record selection priority matrix}

The first temperature station listed in the rows below is selected for each subbasin. If it is determined to have a missing or bad value, the next station is selected.

Subbasin

Greenwater

Upper White

Lower White

South Prairie

Upper Puyallup

Lower Puyallup

Carbon

Temperature station in order of priority for selection

\begin{tabular}{llll}
\hline Buck Creek & Cayuse Pass & Electron & South Prairie \\
Buck Creek & Cayuse Pass & Electron & South Prairie \\
South Prairie & Buck Creek & Cayuse Pass & Electron \\
South Prairie & Buck Creek & Cayuse Pass & Electron \\
Electron & Buck Creek & Cayuse Pass & South Prairie \\
South Prairie & Buck Creek & Cayuse Pass & Electron \\
Electron & Buck Creek & Cayuse Pass & South Prairie
\end{tabular}

Temperature-lapse rate record pairs priority matrix

The first pair of temperature stations listed in the row below is selected for each subbasin. If one of the stations has missing or bad values, one of the next two station pairs is selected depending on which station was rejected.

\begin{tabular}{lll}
\hline Subbasin & \multicolumn{2}{c}{ Temperature station pairs used to compute subbasin lapse rates } \\
\cline { 3 - 3 } Greenwater & Buck Creek-Cayuse Pass & South Prairie-Cayuse Pass or South Prairie-Buck Creek \\
Upper White & Buck Creek-Cayuse Pass & South Prairie-Cayuse Pass or South Prairie-Buck Creek \\
Lower White & South Prairie-Electron & Electron-Buck Creek or South Prairie-Buck Creek \\
South Prairie & South Prairie-Electron & Electron-Buck Creek or South Prairie-Buck Creek \\
Upper Puyallup & Electron-Cayuse Pass & South Prairie-Cayuse Pass or South Prairie-Buck Creek \\
Lower Puyallup & South Prairie-Electron & Electron-Buck Creek or South Prairie-Buck Creek \\
Carbon & Electron-Cayuse Pass & South Prairie-Cayuse Pass or South Prairie-Buck Creek \\
\hline
\end{tabular}




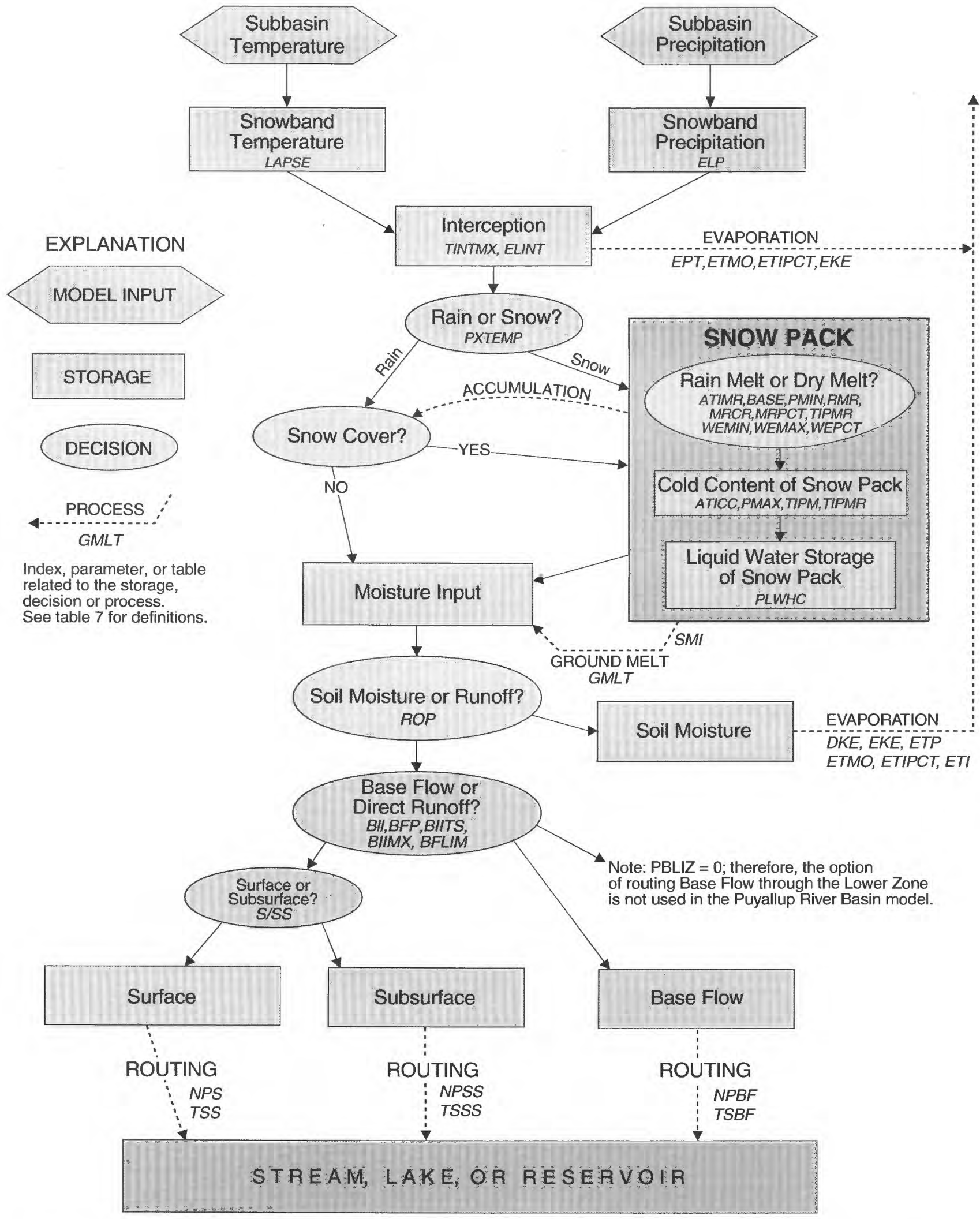

Figure 7. Flow chart of the simulated runoff from a snowband for the Puyallup River Basin model, Washington. 
Table 7. Definitions of indexes, parameters, and tables used in the model characteristics file that define the hydrologic processes and parameters used in the Puyallup River Basin model, Washington

[PET, potential evapotranspiration, in inches; --, no default value]

\begin{tabular}{|c|c|c|}
\hline Indexes & \multicolumn{2}{|l|}{ Definition } \\
\hline ATICC & \multicolumn{2}{|c|}{$\begin{array}{l}\text { Index to the snow temperature near the surface, in degrees Fahrenheit, used to calculate snow pack } \\
\text { cold content }\end{array}$} \\
\hline ATIMR & \multicolumn{2}{|l|}{ Temperature index, in degree days, used to determine snow pack dry-melt rates } \\
\hline BII & \multicolumn{2}{|c|}{$\begin{array}{l}\text { Base flow infiltration index, in inches per } 24 \text { hours, used to partition runoff as direct flow or base } \\
\text { flow }\end{array}$} \\
\hline ETI & \multicolumn{2}{|l|}{ Evapotranspiration index, in inches, used to compute PET } \\
\hline SMI & \multicolumn{2}{|c|}{$\begin{array}{l}\text { Soil moisture index, in inches, an indicator of relative soil wetness used to partition moisture input } \\
\text { into runoff or soil moisture. }\end{array}$} \\
\hline$\underline{\text { Parameters }}$ & Definition & Default value \\
\hline BASE & Base temperature for snowmelt, in degrees Fahrenheit & 32.0 \\
\hline BFLIM & Base flow input limit, in inches & -. \\
\hline BIIMX & BII maximum value, in inches & -- \\
\hline BIITS & Base flow infiltration time of storage, in hours & -- \\
\hline ELINT & Tree line elevation for interception, in feet. & 100,000 \\
\hline LAPSE & Subbasin temperature lapse rate, in degrees per 1,000 feet & 3.3 \\
\hline NPS & Number of surface routing phases & -- \\
\hline NPSS & Number of subsurface routing phases & -- \\
\hline NPBF & Number of base flow routing phases & -- \\
\hline PBLIZ & Percent of baseflow input to lower zone (zero in Puyallup River model) & 0.0 \\
\hline PLWHC & Liquid water holding capacity of snow as a percent of water equivalent of snowpack & 0.03 \\
\hline PMIN & Minimum rain for rain melt to occur, in inches per hour & 0.017 \\
\hline PMAX & Threshold precipitation rate, in inches per hour for the calculation of ATICC & 0.0333 \\
\hline PXTEMP & Rain-freeze temperature, in degrees Fahrenheit & 35.0 \\
\hline RMR & Snowmelt rate during a rain period, in inches per degree-day & 0.074 \\
\hline SNETF & Ratio of evapotranspiration over snow that computed PET is reduced. & 0.9 \\
\hline TINTMX & Maximum precipitation interception, in inches & 0.2 \\
\hline TIPMR & "Die-away" coefficient used in the calculation of the ATIMR index & 0.98 \\
\hline TIPM & "Die-away" coefficient used in the calculation of the ATICC index & 0.84 \\
\hline TSS & Surface flow time of storage in hours & -- \\
\hline TSSS & Subsurface flow time of storage in hours & -- \\
\hline TSBF & Baseflow time of storage in hours & -- \\
\hline WEMIN & Minimum snow-water equivalent, in inches for unrestricted dry-melt of snow pack & 2.0 \\
\hline WEMAX & Maximum snow-water equivalent, in inches for restricted dry-melt of snow pack & 0.4 \\
\hline WEPCT & Percentage of snow-water equivalent per day below WEMIN that can be melted & 60 \\
\hline$\underline{\text { Tables }}$ & $\underline{\text { Definition }}$ & \\
\hline BFP & Percent of runoff to baseflow based on BII values & \\
\hline DKE & Adjustment to PET or the ETI index when soil moisture becomes depleted. & \\
\hline EKE & Adjustment to PET or the ETI index based on rainfall intensity & \\
\hline ETIPCT & Elevation in feet versus percent effectiveness of ETI & \\
\hline ELP & $\begin{array}{l}\text { Elevation in feet of midpoint of snowband versus percent of subbasin precipitation a } \\
\text { snowband }\end{array}$ & applied to \\
\hline ETMO & Percent effectiveness of ETI versus month & \\
\hline ETP & Daily unadjusted PET based on air temperature & \\
\hline GMLT & Groundmelt in inches per day versus month & \\
\hline MRCR & ATIMR index versus dry-melt rate and cold rate & \\
\hline MRPCT & Percent effectiveness of the snow pack dry-melt rate versus month & \\
\hline ROP & SMI versus runoff percent of moisture input & \\
\hline S/SS & Input to surface flow path in inches per hour versus input of direct runoff in inches $p$ & oer hour \\
\hline
\end{tabular}




\section{Snow Accumulation, Conditioning, and Melt}

Because snowmelt contribution to runoff can be an important factor in floods, simulated contributions of snowmelt to runoff must be accounted for continuously. The depletion version of the SSARR model has an option of an energy-budget approach for simulating snowmelt, but such a data-intensive approach was not used. Instead, a temperature-index approach was chosen. Surface air temperature, which is strongly related to elevation and is the single most reliable index to snowmelt (Linsley and others, 1982, p. 253), is the sole index of energy exchange at the top of the snowpack used in the SSARR temperature-index algorithms.

Simulated snow accumulates at an even depth throughout an individual subbasin snowband when precipitation occurs if interception storage (TINTMX) has been satisfied and the temperature is below the rain-freeze temperature (PXTEMP). The simulated snowpack melts at the top by application of either a clear-weather melt equation or a rainy-weather melt rate (RMR) and at the bottom (groundmelt) at a rate that varies seasonally according to a table of monthly values (GMLT). Parameters and tables controlling simulated clear-weather melt and groundmelt are most important for correctly simulating the size of the snowpack, measured in inches of snow-water equivalent, before a storm, and the RMR is important in determining the contribution of snowmelt to runoff during a rain storm.

Melt water from the top of the snow pack must travel through the pack before becoming runoff. The snow pack "cold content" and "liquid water" deficits must be satisfied before melt water traveling through the snowpack is available for runoff. Satisfying these deficits is part of the snowpack conditioning and follows the same algorithms used by Anderson (1973) in his temperature-index, snow accumulation, and ablation model.

\section{Partitioning Moisture Inputs}

Liquid water from rain or snowmelt either increases soil moisture or becomes direct or baseflow runoff. The portion of liquid water that the model uses to increase soil moisture is a function of the simulated water already present in the soil, which is represented by the soil moisture index (SMI), in inches of water. As SMI increases, the percentage of moisture input available for runoff increases, and the percentage going to soil moisture decreases as defined in the runoff percentage table (ROP). Precipitation intensity may also influence the runoff percentages, but this option was not used in the Puyallup
River Basin model. Simulated water in soil moisture storage can only be depleted through evaporation. All of the liquid water input not going to soil moisture becomes runoff as either base flow, representing shallow to intermediate ground-water discharge, or direct runoff, representing surface or shallow subsurface runoff. A runoff pathway through deep ground water called "lower zone" in SSARR (U.S. Army Corps of Engineers, 1991, p. 23) is generally used to simulate the "long term" component of baseflow. This pathway was not used in the Puyallup River Basin model because the focus of the runoff simulations was on high flows, which are not significantly affected by long-term baseflow runoff. Similar to the ROP table, a base-flow percentage (BFP) table computes the percentage of available runoff that is base flow as a function of the base-flow infiltration index (BII). Other parameters define limits to the index (BIMX), limits to the base flow runoff (BFLIM), and a time of storage delay (BIITS).

Simulated water not going to base flow or soil moisture becomes direct runoff and is partitioned as surface runoff (S) or subsurface runoff (SS). A table (S/SS) is provided to the program by the user to define the partitioning of available direct runoff as a function of the input rate in inches per hour. General guidelines for this relation are that (1) surface runoff is always at least 10 percent of the direct runoff and (2) the subsurface flow rate begins at zero, reaches a maximum rate when the rate of direct runoff is twice the maximum subsurface rate, and remains constant for increasing rates of direct runoff (U.S. Army Corps of Engineers, 1991, p. 24).

\section{Routing of Surface, Subsurface, and Base Flow Runoff from Subbasins to Streams}

The routing of available rainfall and snowmelt from the subbasins to streams represents delays in flow that naturally occur in the subbasin. Actual base flow will have delays on the order of weeks and months as water travels through the ground-water system, subsurface runoff will have delays of days or weeks, and surface runoff delays are generally measured in hours. The model uses a storage-routing technique that divides the water available for runoff into a specified number of increments of storage (phases) and applies a specified time of storage to the phases. Increasing the number of phases and time of storage will add longer delays to the outflow hydrograph from the subbasin, tending to attenuate the hydrograph. The partitioning of runoff into the three flow paths is computed in inches per hour and then converted to cubic feet per second based on the drainage area of the subbasin. The simulated outflow hydrograph from the subbasin can be 
compared directly to the observed hydrograph recorded at a gage site if one is available. In the Puyallup River Basin model, comparisons between the observed and simulated subbasin outflow hydrographs are made for the Greenwater, Carbon, upper White (including flow from the Greenwater subbasin), upper Puyallup, and South Prairie subbasins. No comparisons are made with the two lower subbasins because there are no representative observed records of runoff from these subbasins.

\section{Stream Network}

For the purposes of modeling, a river system is represented by a network of one-dimensional channel reaches, lakes, reservoirs, and summary points (fig. 8). Subbasins generate runoff that becomes inflows to the network. All inflows to river reaches enter at their upstream ends, and all outputs exit through their downstream ends. The SSARR model uses summing points to add or subtract flows at junctions of reaches; adjacent stations to route stream flows through channels where flow is a specified function of the flow in another reach; reservoirs to simulate the effects of dams; and balancing stations where the flow is specified as the difference between outflows from two reaches or between an observed and a simulated outflow.

In the Puyallup River Basin model, diversions from the White River into the White River Canal are simulated by CANALA, an adjacent station, and CANALB, a summing point. The flow at CANALA is set equal to the flow at the White River Canal gage (USGS station number 12099000). During a forecast model run, estimates of the diversions are obtained from Puget Power, the utility that operates the canal, and supplied to the model as flows for White River Canal at Buckley. Summing point CANALB subtracts an amount of water from SUM2 equal to the flow specified for CANALA.

It is worth noting that discharge of the White River at the gage near Buckley (USGS station number 12098500) is not available in real time because the stage-discharge relation (rating) used to compute discharges from observed stage is not stable. However, the record is published and is generally considered fair to good after the rating is adjusted at the end of the water year using information gathered from discharge measurements made at the site. The operational system uses only the stage information at this site.

\section{Flow In Channels and Reservoirs}

The travel time through and the attenuation of peak discharges by river channels, lakes, and reservoirs can significantly influence the shape of downstream hydrographs. In the Puyallup River Basin model, flow routing begins with the inflow to Mud Mountain Lake on the White River, at the mouth of South Prairie Creek on the Carbon River, and near Orting (USGS station number 12093500) on the main stem of the Puyallup River. Routing continues downstream to near the mouth of the Puyallup River (USGS station number 12101500).

Flow routing in two of the channel reaches, REACH2 and REACH5, of the model is controlled by a storagerouting equation that routes the flow incrementally. In the routing equation, the shape of the outflow hydrograph from a channel reach is affected by the number of phases (increments) and the time of storage, both provided by the user. Increasing the number of phases will decrease the peak discharge and increase the time of storage, causing greater attenuation of the outflow hydrograph (U.S. Army Corps of Engineers, 1991, p. E-3). The user also provides values for the parameters $n$ and $K T S$ to determine a time of storage, $T_{s}$, for each phase:

where

$$
T_{s}=\frac{K T S}{Q^{n}},
$$

KTS is a coefficient determined by calibration,

$Q$ is discharge, in cubic feet per second, and

$n$ is a coefficient, usually between -1 and 1 , also determined by calibration.

Larger values of KTS and smaller values of $n$ tend to attenuate the discharge hydrograph. The User's Manual (U.S. Army Corps of Engineers, 1991, p. E-3 to E-9) provides typical values and tables to make initial estimates of the parameters that require a series of trial-and-error model runs to calibrate. Time of storage can also be provided as a table of discharges versus time of storage, as was done for reaches 1,3 , and 4 . These tables were taken from the NWS Northwest River Forecast Center's Puyallup River Basin model (Chuck Orwig, National Weather Service, Northwest River Forecast Center, National Weather Service, written commun.,1993). 


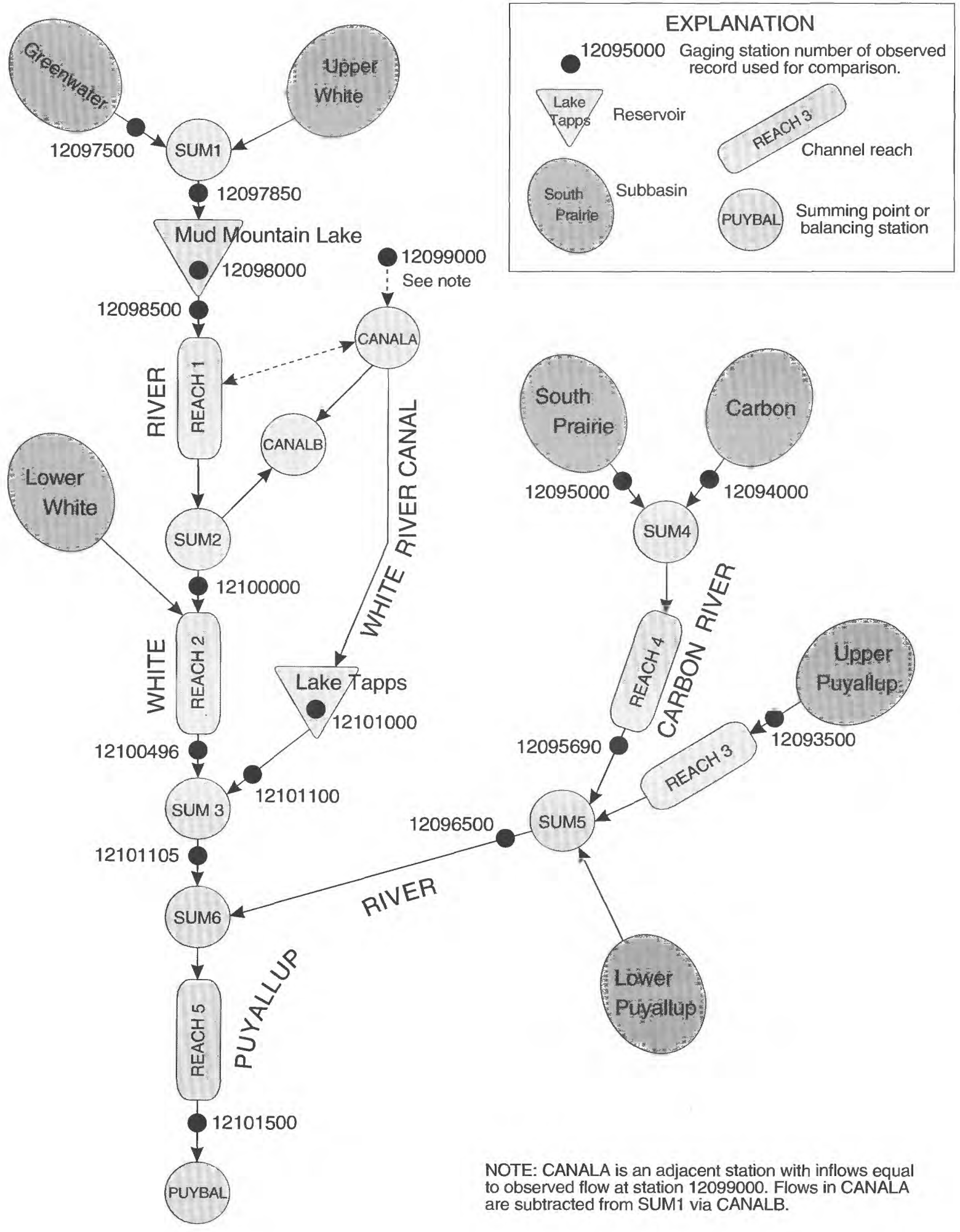

Figure 8. Schematic diagram of the network of subbasins, channel reaches, reservoirs, and summing points used in the Puyallup River Basin model, Washington. 
In the Puyallup River Basin model there are two reservoirs, Mud Mountain Lake and Lake Tapps, that can store water and affect flows. The Electron diversion has little storage capability and little effect on flows other than slight changes in timing, most notable during low flows when the travel time through the flume is less than through the natural channel reach. The diversion of water from the Puyallup River and through the Electron Powerhouse was ignored in the Puyallup River Basin model because of its small effect on flood flows in the river.

Routing through a reservoir is based on a user-provided table of discharge and storage for various levels of stage in the reservoir. Free-flow outflow is determined from the storage and relations between storage, stage, and discharge. Controls on the simulated outflow, however, may be made by specifying a time series of outflow discharges or reservoir stages. In the Puyallup River Basin model, simulated outflow from Lake Tapps equals observed discharge at Lake Tapps Diversion (station number 12101100); and simulated outflow from Mud Mountain Lake is computed using observed stage and a relation of lake stage to storage-simulated outflow equals the simulated inflow minus the change in storage. When lake stage is missing (possible during real-time applications), simulated outflow from Mud Mountain Lake equals the addition of the observed discharges of the White River at Buckley (USGS station number 12100000) and of the White River Canal at Buckley (USGS station number 12099000).

Generally, the controls on the simulated outflow are used. During forecast model runs, the outflows for Mud Mountain Dam, inflows to the White River Canal, and outflows for Lake Tapps must be estimated in order to use the controls on simulated outflow. There are times when controls should not be used for Mud Mountain Dam. With controls, the simulated flows from Mud Mountain Dam can be wildly unstable when there is little or no storage, which is common during nonflood conditions. If the simulated inflow is not enough to maintain specified outflows or lake stage, then negative outflows are computed to conserve mass. At these points in time, the outflow or stage often fluctuates dramatically from negative values to unreasonably large positive outflows. If this problem occurs, the model run can be rerun by specifying that the storage remains constant, which causes free flow to occur-outflow equals inflow.

The stage at several sites critical to PCRI operations is determined from simulated discharges and the stage-discharge relationships (ratings) at these sites. These sites include Puyallup River near Orting (12093500), Carbon
River at Orting (12095690), Puyallup River at $A$ lderton (12096500), White River near Auburn (121004ㅇ), and Puyallup River at Puyallup (12101500).

\section{Automated Adjustment of Simulated Runoff}

The SSARR model can automatically adjust runoff simulations for individual subbasins to the observed record with the ADJUST command. The common use for this command is to make adjustments to the observed gage values of precipitation and and (or) temperature just prior to a forecast model run to make sure that certain initial conditions for the run, such as stream discharges, match the observed conditions at the last time step for which the observed data are available. By this method, much of the error that may have accumulated prior to the forecast model run is eliminated. These adjustments are not carried forward into the forecast simulations.

In the first step of the automated adjustment procedure, a time series of differences between simulated and observed discharges is computed. The model uses these differences and an attribution table (table ATTR1 in the Puyallup River Basin model) to estimate the error that potentially can be corrected by changing the avi ilable water for runoff at a particular time. The estima ${ }^{+}$d correction $E_{i}$ at time step $i$ is computed as

$$
\begin{aligned}
E_{i} & =P_{i}\left(S_{i}-O_{i}\right) \\
& +P_{i+1}\left(S_{i+1}-O_{i+1}\right)+\ldots \\
& +P_{i+n}\left(S_{i+n}-O_{i+n}\right)
\end{aligned}
$$

where

$P_{i}$ is the percent of total runoff for time, $i$, from the attribution table;

$S_{i}$ is simulated discharge for time $i$;

$O_{i}$ is observed discharge for time $i$; and

$n$ is the number of time steps in the attribution table.

The attribution table (fig. 9) is analogous to a urit hydrograph that defines the amount of runoff in a basin over time for a given input of rainfall. The table, ATTR1, was generated from a simulated unit hydrograph for the South Prairie Creek Basin for a 24-hour period and is used for all the basins that use the ADJUST procedure. 


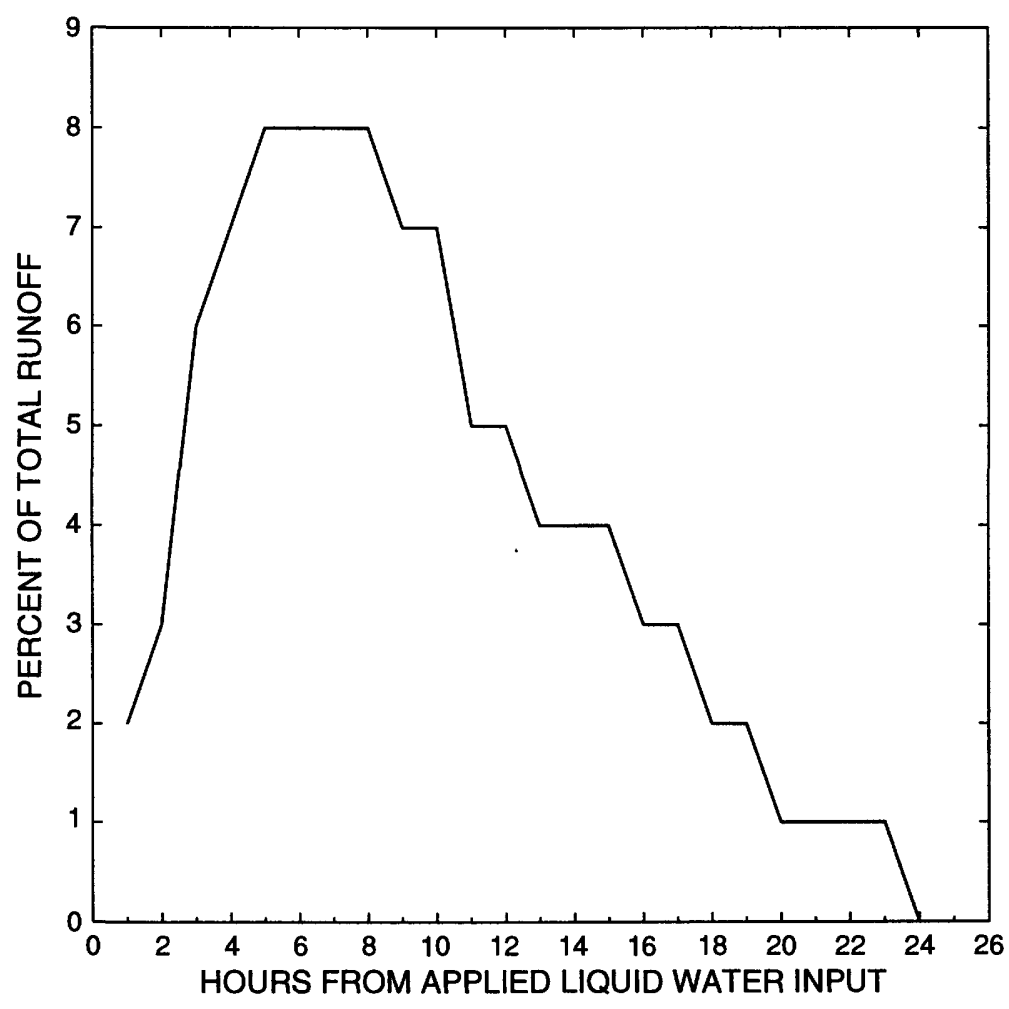

Figure 9. Simulated hourly subbasin runoff response to liquid water input defined by attribution table ATTR1 in the Puyallup River Basin model, Washington.

The next and final step in the adjustment procedure is to run a set of trial simulations in which lapse rate, temperature, and precipitation are adjusted by varying amounts. The first two are adjusted only if snow is present. The model will iterate a specified number of times (10 in the Puyallup River Basin model) or until a simulated discharge is within a specified range (5 percent of observed discharge for the Puyallup River Basin model). If the model has undersimulated runoff (observed is greater than simulated discharge) during a particular time period and snow is present in the snowband, the lapse rate is first lowered within specified increments $\left(0.5^{\circ} \mathrm{F}\right.$ per 1,000 feet elevation for the Puyallup River Basin model) to raise basin-averaged temperature and increase snowmelt and thus increase runoff. If more adjustment is needed to correct the undersimulation, temperature is increased by a specified increment $\left(0.5^{\circ} \mathrm{F}\right.$ for the Puyallup River Basin model), and finally if more adjustment is needed, precipitation is increased by a specified increment $(0.2$ inch for the Puyallup River model). The process is repeated until the maximum allowable number of trials have been made or the error is within the specified tolerance. The trial with the smallest squared-error of differences between s:mulated and observed is chosen by the SSARR model as the final adjusted simulation.

In order for the ADJUST routine to work, a record of observed basin outflow is needed, which limits the application of the routine in the Puyallup River Basin model to the South Prairie, Greenwater, upper Puyallup, Carbon, and upper White subbasins. The observed record for the upper White subbasin is obtained by subtracting the observed flows at station number 12097500 , Greenwater at Greenwater, from observed flows at station number 12097850, White River below Clearwater River.

A different process is used to adjust simulated outflow values for REACH5. At a "balancing" station called PUYBAL, the differences between outflows from REACH5 and the observed discharge of the Puyall " $?$ River at the Puyallup gage (PUYOBS) is computed (see fig. 8). Afterwards, the differences may be added to the inflow to REACH5. 


\section{SIMULATION RESULTS}

This section reports the results of simulations of eight of the largest storms that occurred during the calibration and validation period of this project (water years 1994 through 1997). The section also reports the results of several sensitivity analyses and comparisons of simulated and observed snow-water equivalent and precipitation, which are provided to give readers a feel for the various sources of errors and their relative magnitudes. This section begins by describing the guidelines used to attain the final calibrated SSARR model. They closely follow the methods used during real-time operation of the model, including making simulations using the latest observed data, generally 1 to 4 hours behind the current time. Forecast operation of the model uses forecasted input data to make 54-hour simulations with 6-hour time steps beginning at the end time of the most recent real-time simulation. The results of forecast simulations are not given in this report because the format, availability, and station location of the forecast data points have changed several times throughout this project.

\section{Approach to Calibration and Validation of the Numerical Model}

To attain the final set of model characteristics and tables, the investigation began with the characteristics and tables supplied by the NWS for its model of the Puyallup River Basin (preliminary model) and adjusted them as necessary to reduce simulation error (differences between the observed and simulated peak discharges and runoff volumes). Calibration is a trial-and-error process that involves adjusting parameter values until there is a reasonable agreement between simulated and observed streamflow hydrographs. For the snow-accumulating parameters not found in the NWS's depletion version of the SSARR model, default values were taken from the literature. Because streamflows at the mouths of the lower White and lower Puyallup subbasins were not gaged, parameters for these subbasins were assigned values similar to their nearby subbasins.

The procedures used for calibration and validation model runs were the same as those that are expected to be used for real-time simulations. Calibration and validation simulations were begun on the beginning of the water year, October 1, except for water year 1996, for which simulations were begun on September 20 to account for an unseasonably large amount of precipitation during the last week of September 1995. Initial conditions specified for the subbasins represented the relatively dry soil conditions at the end of summer in the Pacific Northwest. Initial conditions of the reaches were based on average October 1 streamflow discharges for water years 1990 to 1996.

Real-time model operation uses 1-hour time steps in a "storm" mode and 6-hour time steps when in a "ackup" or "nonstorm" mode and for forecast model runs. For the calibration and validation model runs, simulatiors were run at a 6-hour time step until 4 days before the day of the peak recorded at the upper basin stream gages. (Sometimes the peak discharge occurred later at downs'ream gages because of regulation or travel time). The simulation was stopped at midnight and then restarted with a 1-hour time step (storm mode) and run for 8 day: If additional calibration peaks occurred in the water yerr, simulation restarted in backup mode until 4 days before the next calibration. During real-time operation, the model would generally be stopped at the last date when observed discharge was available just before a flood was expected to occur, and the automated adjustment procedures would be used to correct the simulated values to agree with the observed values. However, this was not done during calibration and validation because it would mask errors in the model that the calibration process is designed to correct.

Calibration of the flow routing in the reache : was limited to only two reaches, REACH2 and REACHs, because observed discharge records were available for urstream and downstream end points of only these two rerches. In most floods, the flow velocities are relatively high on the Puyallup River; therefore, the translation of the f nod peak from the upstream end of a reach to the downstream end of a reach is usually less than several hours. Also, when floodwaters are contained within the river banks. channel storage has minimal attenuating effects on discharge peaks. Calibration of REACH2 and REACH5 was done with some of the highest available flows, which were all contained within the banks or levees of the river, so the differences between the upstream and downstream hydrographs were small compared to errors in the simulation of runoff from the watersheds. It should be noted that an actual large breach of a channel bank or levee w:"l likely send flow into storage and increase the downstream travel time of the peak. All of the reach calibrations were made when the flow was entirely within the main chan "el; therefore, in the case of a channel bank or levee breach, the simulated downstream peak may be higher and nccur sooner than the observed peak. Figure 10 shows observed flow at the White River at Buckley gage representing the upstream inflow to REACH2, observed flow at the White River near Auburn gage, which represents the ortflow from REACH2, and simulated outflow from REACH2. 


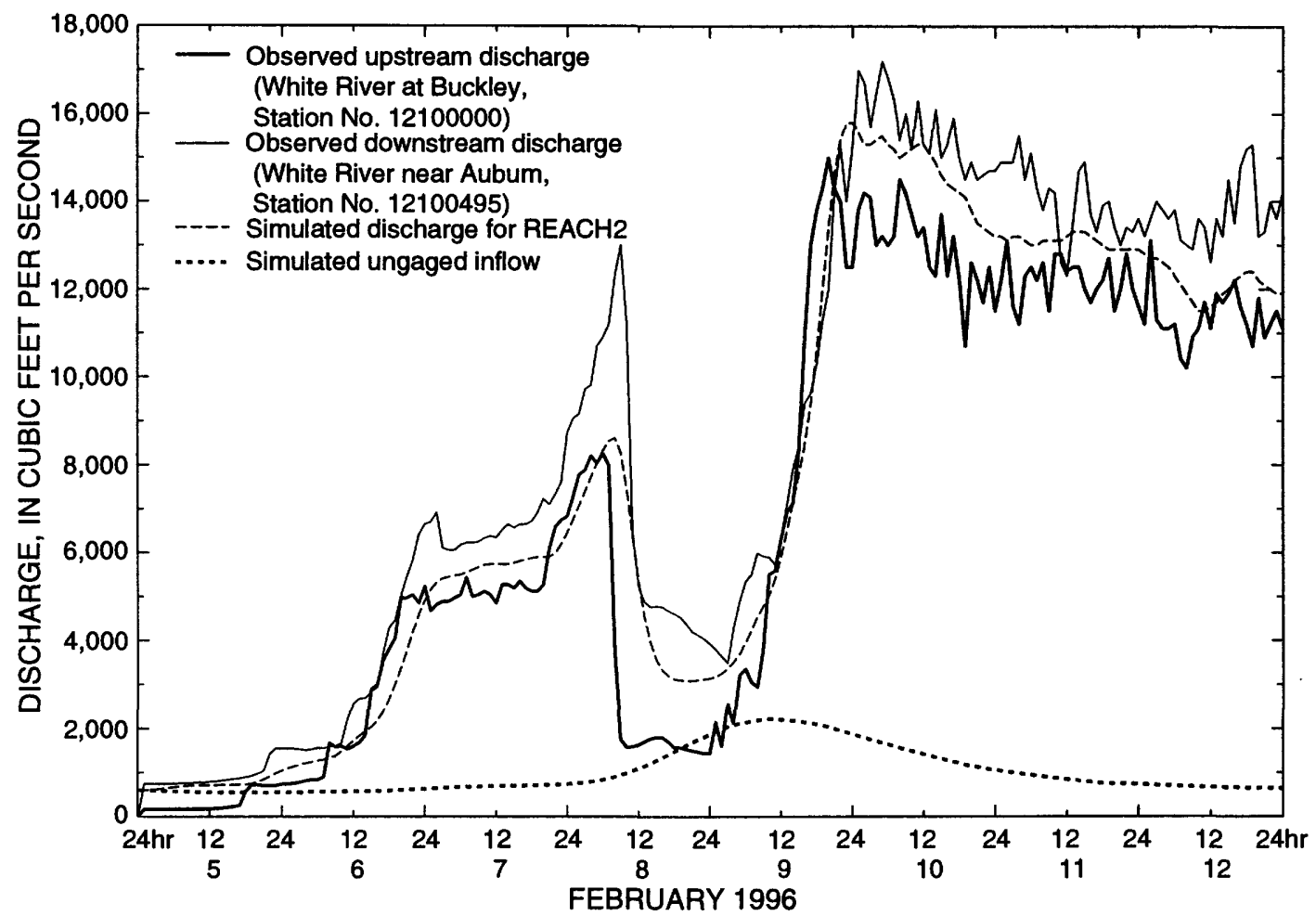

Figure 10. Simulated outflow discharge from REACH2 of the Puyallup River Basin model, simulated ungaged inflow to REACH2, observed upstream inflow to REACH2 at White River at Buckley, and observed outflow at White River near Auburn during February 5-12, 1996, Puyallup River Basin, Washington.

Simulated ungaged runoff from the lower White subbasin was added at the upstream end of REACH2 (fig. 8). The reach is 17 miles long but shows little attenuation of the hydrograph. No error analysis was performed on the reach calibrations.

\section{Calibration and Validation of the Numerical Model}

Four storms were selected for use in calibration. The first three occurred during the 1995 water year, and the fourth was the February 1996 storm, an exceptionally large event in the Puyallup River Basin. After a model was calibrated, the parameters were held constant and used to simulate runoff during four other storms designated as the validation period for the model. The validation storms included two 1996 water-year storms that occurred before the February 1996 peak and two storms in the 1997 water year.
Snow-water equivalent (SWE) data for the Fet ruary 1996 storm were available from the National Operational Hydrologic Remote Sensing Center (NOHRSC) of the NWS. Adjustments of the snow-related parameters were made during a series of model runs (calibrations) to match the simulated SWE with the NOHRSC estimated $S{ }^{\top} / E$ as well as possible. After these calibrations were made, these parameters were held constant throughout all the additional calibration and validation runs.

The model showed a strong seasonal bias to urdersimulate storm runoff volume and peak discharges during late fall and early winter and to oversimulate these variables during late winter and early spring. The initi-1 SMI at the beginning of the water year was increased, and the preliminary runoff percentage (ROP) tables were modified (fig. 11) to increase runoff early in the season and decrease it late in the season. 


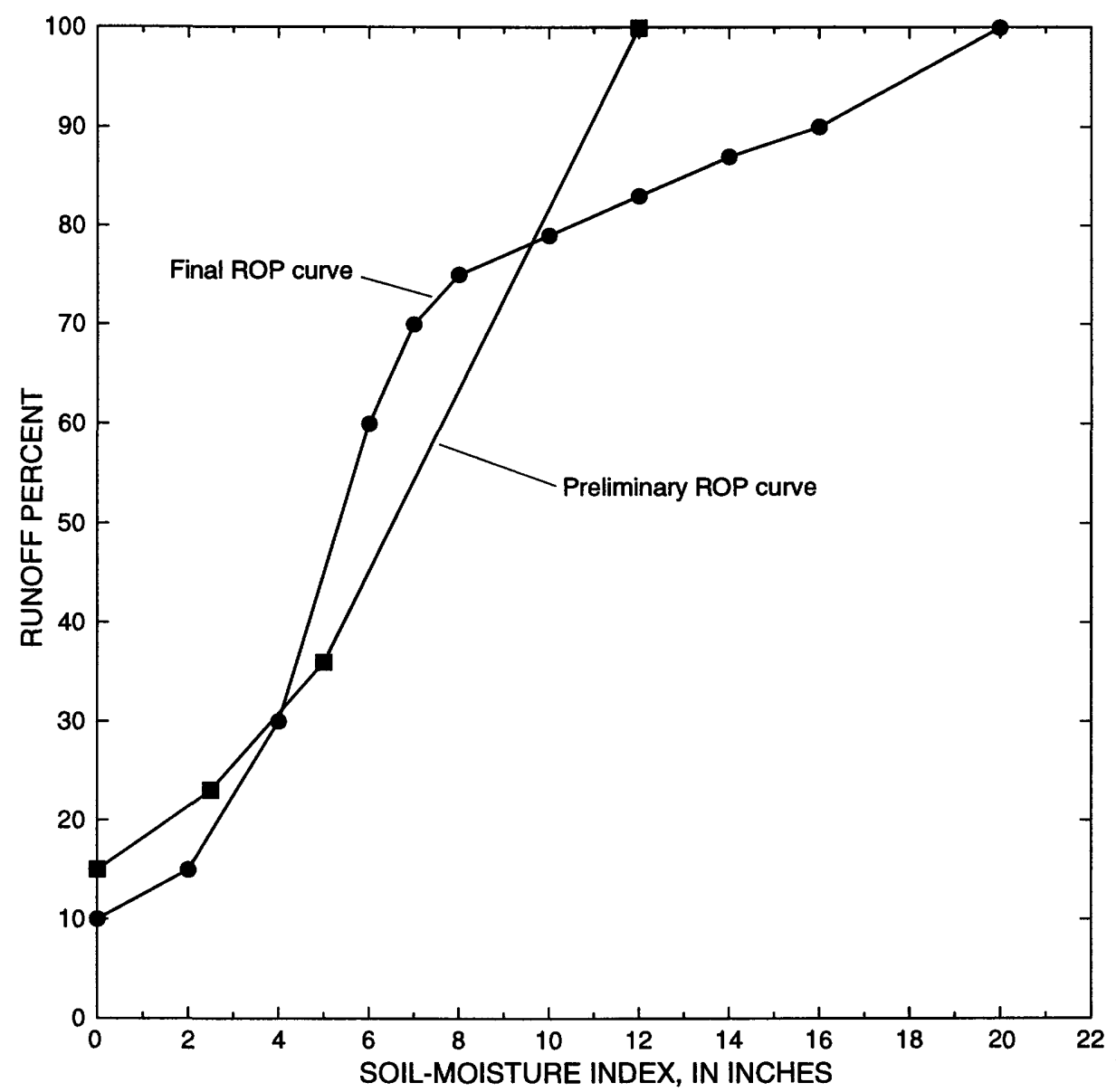

Figure 11. Preliminary and final runoff percentage (ROP) curves for the upper Puyallup subbasin in the Puyallup River Basin model, Washington.

The preliminary model used a precipitation adjustment weight of 100 percent (no adjustment) for all the subbasins. In the final model, the precipitation adjustment weight for the Carbon subbasin was increased to 120 percent because earlier model runs were consistently underestimating runoff. Conversely, because earlier model runs were consistently overestimating runoff from the South Prairie and Greenwater subbasins, in the final model, the precipitation adjustment weight for South Prairie subbasin was reduced to 85 percent and the weight for the Greenwater subbasin was reduced to 75 percent.

\section{Comparison of Simulated Extent of Snow Cover with Observed Extent}

Direct measures of SWE in the Puyallup River Basin are available for two sites with snow pillows: (1) Corral Pass, operated by the Natural Resources Conservation Service (data are usually gathered only from January to June), and (2) Cayuse Pass, operated by the USGS. With data from only these two sites available, some form of indirect measurements of SWE was needed to ev'luate the snowmelt contribution to runoff in order to calib ate the snow parameters in the watershed model. This was done for the February 1996 flood using gridded estimates of SWE obtained from the NOHRSC estimates. Estimates for February 1, 13, and 28, 1996, were obtained from the NOHRSC internet web site.

The SWE values from the NOHRCS web si ${ }^{+}$, were estimated by a "modified elevation detrending" method that uses satellite images of the extent of snow cover, a digital elevation model, and observations of SW: where they are available. Using all three sets of data, N'OHRSC developed a linear relationship between elevation and SWE, and estimates of SWE were obtained for grid points at a spacing of approximately 0.4 mile ( 0.6 kiloneter) (Hartman, Rost, and Anderson, 1996). In that paper the authors offer the following comment on their methodol- 
ogy: "very little confidence should be placed on individual pixel [grid] values. However when integrated with [in] hydrologic basins, the results appear to be credible."

When NOHRSC estimates of SWE were compared with measured values of SWE at the Corral Pass site in the Puyallup River Basin and two other Natural Resources Conservation Service (NRSC)-operated sites in nearby basins (unfortunately, no usable data were available from the Cayuse Pass site for the February 1996 flood), there was reasonable agreement between estimated and measured values of SWE (table 8). In this comparison, the means of the NOHRSC estimates over representative areas, which varied in size from 2.5 to 12.1 square miles surrounding the snow-pillow sites, were used. Nine of the 12 NOHRSC estimates were within 3 inches of the observed values; however, all of the estimates were less than the observed values, with the largest difference (19.4 inches) occurring on February 13 for Corral Pass, the site at the highest elevation.

By use of GIS techniques, the subbasin total SWE and elevation-zone totals were computed from the basin-wide estimates of SWE from NOHRSC, thus allowing direct comparison with simulated results. SWE values simulated for subbasins are biased high in the high-elevation snowbands and biased low in the low-elevation snowbands, but are in reasonably close agreement with the NOHRSC esti- mates in the midelevation snowbands (table 9). Of the five upper basins, the two lower elevation subbasin South Prairie and Greenwater, generally had less simulated SWE than the NOHRSC estimates, while the higher elevation subbasins consistently had higher simulated SWE values. Simulated values on February 13, 5 days after the peak flooding, are almost all significantly larger than the NOHRSC estimates. Adjustment of the srow parameters, especially the snowmelt-rate-during-ra'nfall parameter, RMR, could have allowed more snow to melt and reduced the simulated February 13th SWE values. Several calibration runs were made to increase sno'vmelt, but they resulted in simulated peak discharges unreasonably larger than the observed values. Consequently, a value of RMR was chosen that compromised between errors of oversimulating peak discharges and of oversimulating snowmelt. Although there is an apparent bias of oversimulating SWE in the upper elevations and undersimulating SWE in the lower elevations, the final parameters were not adjusted to remove the bias because the same bias is indicated in the comparison of snow-pillow data and NOHRSC estimates (table 8), and attempts to correct the bias resulted in larger errors between observed and simulated peak discharges. Again, the values represent a balance of errors between SWE values and peak discharge values.

Table 8. Comparison of observed snow-pillow snow-water equivalent values and National Operational Hydroloģic Remote Sensing Center estimates of snow-water equivalent at three sites in or near the Puyallup River Basin, Washington

[NOHRSC, National Operational Hydrologic Remote Sensing Center; NRCS, National Resource Conservation Service]

\begin{tabular}{|c|c|c|c|c|c|c|c|c|}
\hline \multirow[b]{2}{*}{$\begin{array}{l}\text { NRCS } \\
\text { Station name } \\
\text { (elevation, in feet } \\
\text { above sea level) }\end{array}$} & \multicolumn{2}{|c|}{ February 1, 1996} & \multicolumn{2}{|c|}{ February 6, 1996} & \multicolumn{2}{|c|}{ February 13, 1996} & \multicolumn{2}{|c|}{ February $28,199^{\circ}$} \\
\hline & $\begin{array}{l}\text { Observed } \\
\text { snow-water } \\
\text { equivalent } \\
\text { (inches) }\end{array}$ & $\begin{array}{l}\text { NOHRSC } \\
\text { (inches) }\end{array}$ & $\begin{array}{l}\text { Observed } \\
\text { snow-water } \\
\text { equivalent } \\
\text { (inches) }\end{array}$ & $\begin{array}{l}\text { NOHRSC } \\
\text { (inches) }\end{array}$ & $\begin{array}{l}\text { Observed } \\
\text { snow-water } \\
\text { equivalent } \\
\text { (inches) }\end{array}$ & $\begin{array}{l}\text { NOHRSC } \\
\text { (inches) }\end{array}$ & $\begin{array}{l}\text { Observed } \\
\text { snow-water } \\
\text { equivalent } \\
\text { (inches) }\end{array}$ & $\begin{array}{l}\text { NOHR SC } \\
\text { (inches) }\end{array}$ \\
\hline $\begin{array}{l}\text { Cougar Mountain } \\
(3,200)\end{array}$ & 10.9 & 9.5 & 12.6 & 11.3 & 9.5 & 4.7 & 9.1 & 7.3 \\
\hline $\begin{array}{l}\text { Morse Lake } \\
(5,400)\end{array}$ & 31.2 & 29.7 & 36.6 & 33.8 & 38.1 & 35.6 & 43.8 & 41.1 \\
\hline $\begin{array}{l}\text { Corral Pass } \\
(6,000)\end{array}$ & 21.1 & 8.8 & 23.5 & 21.4 & 24.7 & 5.3 & 27.5 & 26.4 \\
\hline
\end{tabular}

\footnotetext{
${ }^{1}$ Mean value of snow-water equivalent estimates for a representative area surrounding the snow-pillow site.
} 
Table 9. Snow-water equivalent for 5 upper basins and for all 13 elevation zones in the Puyallup River Basin, Washington, computed from National Operational Hydrologic Remote Sensing Center (NOHRSC) estimates and simulated by the Puyallup River Basin model, Washington, for 4 days in February 1996

\begin{tabular}{|c|c|c|c|c|c|c|c|c|c|c|c|c|}
\hline \multirow[b]{3}{*}{ Subbasin } & \multicolumn{9}{|c|}{ Snow-water equivalent by subbasin, in inches } & & & \\
\hline & \multicolumn{3}{|c|}{ February 1, 1996} & \multicolumn{3}{|c|}{ February 6, 1996} & \multicolumn{3}{|c|}{ February 13,1996} & \multicolumn{3}{|c|}{ February 281996} \\
\hline & $\begin{array}{l}\text { Esti- } \\
\text { mated }^{1}\end{array}$ & $\begin{array}{l}\text { Simu- } \\
\text { lated }^{2}\end{array}$ & $\begin{array}{l}\text { Diffe- } \\
\text { rence }^{3}\end{array}$ & $\begin{array}{l}\text { Esti- } \\
\text { mated }^{1}\end{array}$ & $\begin{array}{l}\text { Simu- } \\
\text { lated }^{2}\end{array}$ & $\begin{array}{l}\text { Diffe- } \\
\text { rence }^{3}\end{array}$ & $\begin{array}{l}\text { Esti- } \\
\text { mated } 1\end{array}$ & $\begin{array}{l}\text { Simu- } \\
\text { lated }^{2}\end{array}$ & $\begin{array}{l}\text { Diffe- } \\
\text { rence }^{3}\end{array}$ & $\begin{array}{l}\text { Esti- } \\
\text { mated }^{1}\end{array}$ & $\begin{array}{l}\text { Simu- } \\
\text { lated }^{2}\end{array}$ & $\begin{array}{l}\text { Diffe- } \\
\text { rence }^{3}\end{array}$ \\
\hline Greenwater & 10.0 & 7.3 & -2.7 & 14.5 & 8.4 & -6.1 & 6.6 & 7.6 & +1.0 & 13.2 & 7.1 & -6.1 \\
\hline Upper White & 18.2 & 26.6 & +8.4 & 19.9 & 28.8 & +8.9 & 14.7 & 29.5 & +14.8 & 22.8 & 30.6 & +7.8 \\
\hline Upper Puyallup & 15.5 & 20.5 & +5.0 & 16.2 & 22.8 & +6.6 & 10.4 & 24.4 & +14.0 & 17.8 & 25.6 & +7.8 \\
\hline Carbon & 20.0 & 29.7 & +9.7 & 21.1 & 33.6 & +12.5 & 12.4 & 36.4 & +24.0 & 23.8 & 37.7 & +13.9 \\
\hline South Prairie & 7.6 & 2.8 & -4.8 & 6.0 & 3.2 & -2.8 & 0.1 & 2.9 & +2.8 & 5.5 & 3.3 & -2.2 \\
\hline
\end{tabular}

Snow-water equivalent by elevation, in inches

\begin{tabular}{|c|c|c|c|c|c|c|c|c|c|c|c|c|}
\hline \multirow{2}{*}{$\begin{array}{l}\text { Midpoint elevation }{ }^{4} \\
\text { (feet above sea level) }\end{array}$} & \multicolumn{3}{|c|}{ February 1, 1996} & \multicolumn{3}{|c|}{ February 6, 1996} & \multicolumn{3}{|c|}{ February 13,1996} & \multicolumn{3}{|c|}{ February 28.1996} \\
\hline & $\begin{array}{l}\text { Esti- } \\
\text { mated }\end{array}$ & $\begin{array}{l}\text { Simu- } \\
\text { lated }^{5}\end{array}$ & $\begin{array}{l}\text { Diffe- } \\
\text { rence }\end{array}$ & $\begin{array}{l}\text { Esti- } \\
\text { mated }\end{array}$ & $\begin{array}{l}\text { Simu- } \\
\text { lated }^{5}\end{array}$ & $\begin{array}{l}\text { Diffe- } \\
\text { rence }\end{array}$ & $\begin{array}{l}\text { Esti- } \\
\text { mated }\end{array}$ & $\begin{array}{l}\text { Simu- } \\
\text { lated }^{5}\end{array}$ & $\begin{array}{l}\text { Diffe- } \\
\text { rence }\end{array}$ & $\begin{array}{l}\text { Esti- } \\
\text { mated }\end{array}$ & $\begin{array}{l}\text { Simu- } \\
\text { lated }^{5}\end{array}$ & $\begin{array}{l}\text { Diffe- } \\
\text { rence }\end{array}$ \\
\hline 250 & 0.8 & 0.0 & -0.8 & 0.6 & 0.0 & -0.6 & 0.0 & 0.0 & 0.0 & 0.0 & 0.0 & 0.0 \\
\hline 750 & 1.5 & 0.2 & -1.3 & 2.1 & 0.0 & -2.1 & 0.0 & 0.0 & 0.0 & 0.0 & 0.0 & 0.0 \\
\hline 1,250 & 3.4 & 1.4 & -2.0 & 4.0 & 0.5 & -3.5 & 0.0 & 0.0 & 0.0 & 0.3 & 0.2 & -0.1 \\
\hline 1,750 & 3.5 & 2.0 & -1.5 & 3.3 & 1.4 & -1.9 & 0.1 & 0.0 & -0.1 & 1.4 & 0.5 & -0.9 \\
\hline 2,250 & 5.0 & 2.1 & -2.9 & 3.2 & 1.7 & -1.5 & 0.4 & 0.1 & -0.3 & 3.6 & 0.8 & -2.8 \\
\hline 2,750 & 6.6 & 2.4 & -4.2 & 6.4 & 2.5 & -3.9 & 0.8 & 0.6 & -0.2 & 7.4 & 1.1 & -6.3 \\
\hline 3,250 & 11.0 & 4.6 & -6.4 & 9.1 & 6.4 & -2.7 & 1.4 & 4.5 & +3.1 & 12.8 & 4.0 & -8.8 \\
\hline 3,750 & 14.9 & 9.0 & -5.9 & 14.6 & 11.8 & -2.8 & 3.4 & 10.8 & +7.4 & 17.7 & 10.6 & -7.1 \\
\hline 4,250 & 18.1 & 19.1 & +1.0 & 18.6 & 22.8 & +4.2 & 7.6 & 23.8 & +16.2 & 22.6 & 24.6 & +2.0 \\
\hline 4,750 & 21.4 & 25.9 & +4.5 & 23.8 & 29.9 & +6.1 & 10.8 & 34.2 & +23.4 & 27.8 & 35.7 & +7.9 \\
\hline 5,500 & 26.8 & 40.1 & +13.3 & 31.9 & 44.4 & +12.5 & 22.7 & 50.6 & +27.9 & 35.2 & 56.6 & +21.4 \\
\hline 7,000 & 41.6 & 85.7 & +44.1 & 50.1 & 91.1 & +41.0 & 55.2 & 99.0 & +43.8 & 51.6 & 90.2 & +38.6 \\
\hline 11,500 & 72.4 & 138.0 & +65.6 & 78.9 & 103.4 & +24.5 & 108.5 & 159.5 & +51.0 & 85.1 & 146.5 & +61.4 \\
\hline
\end{tabular}

\footnotetext{
${ }^{1}$ National Operational Hydrologic Remote Sensing Center (NOHRSC) estimated snow-water equivalent data.

${ }^{2}$ Simulated snow-water equivalent from the Puyallup River Basin model.

${ }^{3}$ Difference between simulated and estimated snow-water equivalent values.

${ }^{4}$ Midpoint elevation of the elevation zones defined for the Puyallup River Basin model used in this investigation.

${ }^{5}$ Areally weighted average of snow-water equivalent in the elevation zones of five subbasins in the Puyallup River Basin model.
}

\section{Comparison of Observed and Simulated Runoff}

Although the upper White subbasin was not gaged directly, discharge from this subbasin for calibration was obtained by subtracting the discharge from the Greenwater subbasin (USGS station number 12097500) from the discharge of the White River below Clearwater River (USGS station number 12097850). Discharges of the White River at Buckley (USGS station number 12100000) and of the Puyallup River at Puyallup (USGS station number
12101500) are heavily regulated and, therefore, not used to calibrate runoff parameters. Calibration of the runoff parameters focused on the five gaged subbasin?

Many of the same patterns and magnitude : of errors seen for the calibration storms were also seen for the validation storms. Two-thirds of the simulated peak discharges were within 36 percent of the observer peak discharge for the calibration peaks and within 30 percent of the observed peak discharges for the validatinn peaks 
(table 10). Two-thirds of the simulated runoff volumes for the five gaged subbasins were within 17 percent of the observed storm runoff volume for the calibration storms and within 24 percent of the observed storm runoff volume for the validation storms. Errors in simulating peak discharge can be attributed to either incorrectly simulating the amount of water available for runoff or incorrectly simulating the runoff process, or both. Simulated and observed storm runoff volumes were tabulated along with peak discharges in order to assess whether errors in peak discharge were due to incorrect simulation of runoff volume or incorrect runoff parameters.

Figure 12 shows the accuracy and bias of the simulated peak flow and runoff volume from the five gaged watersheds. More data points on each graph fall below the equivalence line, indicating a bias to undersimulate both runoff volume and peak discharge. However, the bias appears to decrease with increasing peak flow and runoff volume. The largest undersimulated flows occurred for the second calibration storm, November 29 to December 3, 1994, when the differences between simulated and observed runoff ranged from -8.1 to -70.3 percent (table 10). Even so, the shapes of the simulated hydrographs matched the shapes of the observed hydrographs for this storm fairly well (fig. 13). There simply was insufficient recorded precipitation to match the simulated runoff to the observed runoff no matter how much the model parameters were adjusted. The calibrated model simulated the largest peak (February 1996) well, closely matching the shape of the hydrograph and the peak (fig. 14).

The summation of errors (table 11) shows that the model tends to undersimulate peak discharge as measured by the bias. Bias is the average of the differences, either positive or negative, and indicates whether the model is oversimulating or undersimulating discharge. The bias is strongly seasonal, despite efforts to reduce the seasonal bias during the calibration process. For all the calibration and validation peaks for the five gaged subbasins, there is a -21.9 percent bias $\left(-1,275 \mathrm{ft}^{3} / \mathrm{s}\right)$ for those peaks that occurred before January 1 of the water year and a +23.4 percent bias $\left(842 \mathrm{ft}^{3} / \mathrm{s}\right)$ for those peaks after January 1. The standard error of estimate (SEE) is the standard deviation of the differences after accounting for the bias. If the differences were normally distributed and there were little or no bias, then about two-thirds of all the differences would be less than or equal to the SEE.

Depending on the grouping of storms, values of SSE range from 16.6 to 40.1 percent (table 11 ).

\section{Sources of Errors}

This subsection discusses three possible reason: for the errors in simulated peak discharges and runoff volumes: (1) errors in the spatial distributions of temperature, precipitation, and SWE; (2) errors in the measurement and calculation of observed discharge; and (3) errors in the representation of the hydrologic runoff processes by the conceptual model and the SSARR model. It is difficult to quantify these errors, but some general comments about each type of error are made in this subsection, and three sensitivity tests on the effects of precipitation and temperature inputs and snow accumulation are described in the following subsection.

Four of the seven temperature stations provide temperature inputs to the real-time model. The model error due to these inputs was relatively small because the chosen stations rarely had missing or bad records and t ? accuracy of the measurements was adequate (the menufacturer's specifications state that measurements are ac ?urate within $0.2^{\circ} \mathrm{F}$, and regular field checks showed that the recorded temperatures generally were accurate within $0.5^{\circ} \mathrm{F}$ ). Also the four chosen stations were adequate to define the lapse rates for most of the runoff-producing range in elevation. Lapse rates above 5,300 feet-the elevation of Cayuse Pass, the highest temperature stationmay be in error, but the percentage of the area of the basin above 5,300 feet and especially above 8,000 feet is small and generally does not contribute much during wint $x$ storms because most of the precipitation is snow. Therefore, temperature errors in these high elevations probably do not contribute significantly to runoff volume or peak-discharge errors.

Precipitation inputs had a much larger potential to create errors in the simulations than did the tempercture inputs. Six precipitation stations were available to provide precipitation inputs to the model. If all precipitation stations had acceptable records and were used, the presipitation network would represent a density of approxim ately one gage per 160 square miles, which may be inade xuate. Also, experience has shown that it is common to have less than all of the six stations with acceptable records bacause many of the gages are unheated and, therefore, misreport actual precipitation during times of snowfall. Certainly, more precipitation gages located in the mid-to-upper elevations that are reliable during snowfall would provide a better measure of the true precipitation and most likely improve the accuracy of runoff simulations. 
Table 10. Observed and simulated storm runoff values per unit area and peak discharge of eight storms used for calibration and validation of the Puyallup River Basin model, Washington

[ft $\mathrm{ft}^{3} / \mathrm{s}$, cubic feet per second]

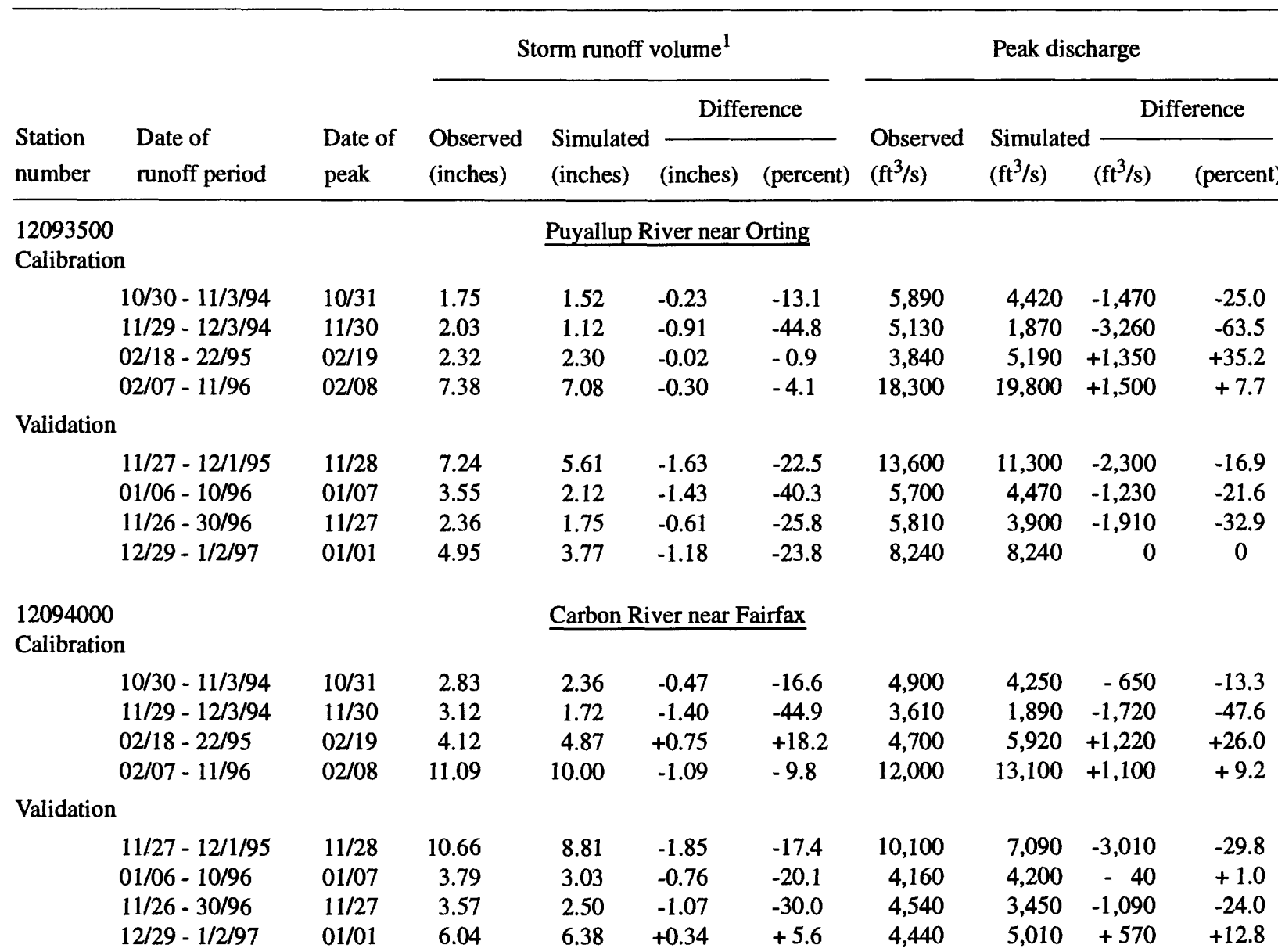

12095000

Calibration

$\begin{array}{ll}10 / 30-11 / 3 / 94 & 10 / 31 \\ 11 / 29-12 / 3 / 94 & 11 / 30 \\ 02 / 18-22 / 95 & 02 / 19 \\ 02 / 07-11 / 96 & 02 / 08\end{array}$

Validation

$\begin{array}{lll}11 / 27-12 / 1 / 95 & 11 / 28 & 5.21 \\ 01 / 06-10 / 96 & 01 / 07 & 1.96 \\ 11 / 26-30 / 96 & 11 / 27 & 2.39 \\ 12 / 29-1 / 2 / 97 & 01 / 01 & 4.99\end{array}$

12097500

Calibration

$\begin{array}{lrr}10 / 30-11 / 3 / 94 & 10 / 31 & 0.80 \\ 11 / 29-12 / 3 / 94 & 11 / 30 & 1.48 \\ 02 / 18-22 / 95 & 0219 & 1.96 \\ 02 / 07-11 / 96 & 02 / 08 & 6.48\end{array}$

$$
\begin{aligned}
& 0.99 \\
& 2.11 \\
& 2.44 \\
& 7.83
\end{aligned}
$$

South Prairie Creek at South Prairie

1.26

$$
+0.27
$$$$
+27.3
$$

1,400

$1.94 \quad-0.17$

$$
\begin{array}{ll}
-8.1 & 2,560
\end{array}
$$

$2.74+0.30$

$+123$

2,680

$\begin{array}{lll}1,390 & -10 & -0.7 \\ 1,880 & -680 & -26.6 \\ 2,940 & +260 & +9.7 \\ 8,110 & -60 & -0.7\end{array}$

$\begin{array}{ll}6.62 & +1.41 \\ 2.54 & +0.58 \\ 1.92 & -0.47 \\ 4.40 & -0.59\end{array}$

$+21.1$

8,170

4,860

$5,880+1,020+21.0$

$2,740+920+50.5$

$\begin{array}{lll}2,020 & -1,210 & -37.5\end{array}$

$-19.7 \quad 3,230$

$3,540+730$

Greenwater River at Greenwater

$\begin{array}{rrlrrrr}0.73 & -0.07 & -8.8 & 1,000 & 763 & -237 & -23.7 \\ 0.44 & -1.04 & -70.3 & 1,180 & 458 & -722 & -61.2 \\ 2.15 & +0.19 & +9.7 & 1,330 & 2,260 & +930 & +69.9 \\ 6.30 & -0.18 & -2.8 & 5,900 & 5,660 & -240 & -4.1\end{array}$


Table 10. Observed and simulated storm runoff values per unit area and peak discharge of eight storms used for calibration and validation of the Puyallup River Basin model, Washington-Continued

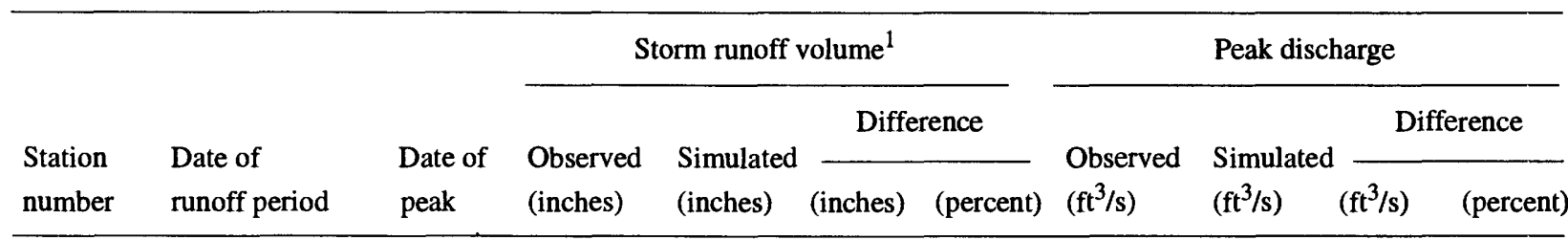

12097500

Validation

$\begin{array}{lll}11 / 27-12 / 1 / 95 & 11 / 28 & 7.12 \\ 01 / 06-10 / 96 & 01 / 07 & 1.79 \\ 11 / 26-30 / 96 & 11 / 27 & 1.11 \\ 12 / 29-1 / 2 / 97 & 01 / 01 & 1.99\end{array}$

12097850

Calibration

$\begin{array}{lll}10 / 30-11 / 3 / 94 & 10 / 31 & 1.19 \\ 11 / 29-12 / 3 / 94 & 11 / 30 & 1.58 \\ 02 / 18-22 / 95 & 02 / 19 & 2.09 \\ 11 / 27-12 / 1 / 95 & 11 / 28 & 4.70 \\ 01 / 06-10 / 96 & 01 / 07 & 1.81\end{array}$

12100000

Calibration

$\begin{array}{lrr}10 / 30-11 / 3 / 94 & 10 / 31 & 0.50 \\ 11 / 29-12 / 3 / 94 & 11 / 30 & 0.73 \\ 02 / 18-22 / 95 & 02 / ? & 0.87 \\ 02 / 07-11 / 96 & 02 / 10 & 3.16\end{array}$

Validation

$\begin{array}{lll}11 / 27-12 / 1 / 95 & 12 / 01 & 2.78 \\ 01 / 06-10 / 96 & 01 / 08 & 1.19 \\ 11 / 26-30 / 96 & 11 / 29 & 0.73 \\ 12 / 29-1 / 2 / 97 & 12 / 31 & 2.70\end{array}$

12101500

Calibration

$\begin{array}{lll}10 / 30-11 / 3 / 94 & 10 / 31 & 1.20 \\ 11 / 29-12 / 3 / 94 & 11 / 30 & 1.43 \\ 02 / 18-22 / 95 & 02 / 19 & 1.95 \\ 02 / 07-11 / 96 & 02 / 09 & 5.31\end{array}$

$\begin{array}{ll}5.15 & -1.97 \\ 1.73 & -0.06 \\ 1.24 & +0.13 \\ 1.75 & -0.24\end{array}$

White River below Clearwater

$\begin{array}{rrrrrrr}1.00 & -0.19 & -16.0 & 7,380 & 6,840 & -540 & -7.3 \\ 0.49 & -1.09 & -69.0 & 7,330 & 2,930 & -4,400 & -600 \\ 2.11 & +0.02 & +1.0 & 7,600 & 13,100 & +5,500 & +72.4 \\ & & & & & & \\ 5.09 & +0.39 & +8.3 & 20,500 & 18,500 & -2,000 & -11.7 \\ 1.56 & -0.25 & -13.8 & 6,000 & 7,290 & +1,290 & +21.5\end{array}$

White River at Buckley

$\begin{array}{rrrrrrr}0.27 & -0.23 & -46.0 & 2,150 & 2,050 & -100 & -4.7 \\ 0.07 & -0.66 & -90.4 & 2,640 & 799 & -1,841 & -69.7 \\ 0.69 & -0.18 & -20.7 & 2,860 & 2,840 & -20 & -07 \\ 3.09 & -0.07 & -2.2 & 11,800 & 11,200 & -600 & -5.1 \\ & & & & & & \\ 2.65 & -0.13 & -4.7 & 13,700 & 11,600 & -2,100 & -15.3 \\ 0.54 & -0.65 & -54.6 & 4,630 & 3,300 & -1,330 & -287 \\ 0.60 & -0.13 & -17.8 & 3,040 & 3,510 & 360 & +15.5 \\ 1.26 & -1.44 & -53.3 & 9,480 & 8,990 & -2,310 & -5.2\end{array}$

Puyallup River at Puyallup

\begin{tabular}{rrrrrrr}
1.06 & -0.14 & -11.7 & 13,400 & 11,100 & $-2,300$ & -17.2 \\
1.12 & -0.31 & -21.7 & 14,000 & 9,790 & $-4,210$ & -301 \\
2.01 & +0.06 & +3.1 & 19,200 & 16,800 & $-2,400$ & -125 \\
5.59 & +0.28 & +5.3 & 46,700 & 45,700 & $-1,000$ & -21 \\
& & & & & & \\
4.94 & +1.18 & +31.4 & 32,600 & 35,900 & $+3,300$ & +101 \\
1.85 & -0.04 & -2.1 & 13,000 & 16,600 & $+3,600$ & -2.1 \\
1.64 & +0.02 & +1.2 & 17,000 & 14,700 & $-2,300$ & -13.5 \\
3.09 & -0.26 & -7.8 & 22,800 & 26,700 & $+3,900$ & +17.1 \\
\hline
\end{tabular}

\footnotetext{
${ }^{1}$ Storm runoff volumes are the 5-day total of daily streamflow volumes for the period of each storm divided by the drainage area $R O=\frac{\text { cubic feet per second-days }}{D A} \times 0.03719$, where $R O$ is runoff in inches, cubic feet per second-day is the 5-days total of mean daily discharges, and $D A$ is the drainage area in square miles.
} 

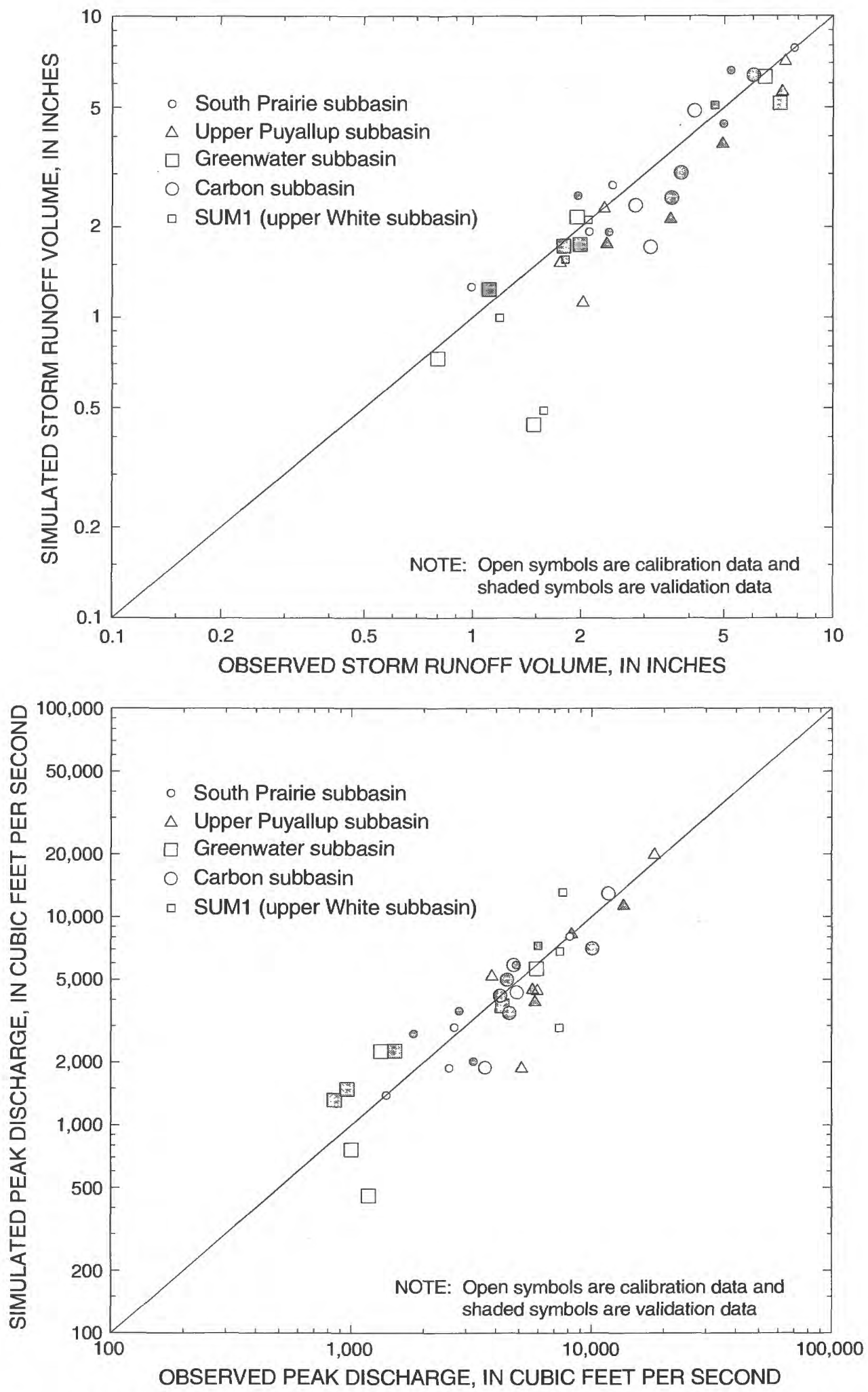

Figure 12. Observed and simulated storm runoff volumes and peak discharge for South Prairie, upper Puyallup, Greenwater, and Carbon subbasins and summation point SUM1, Washington. 

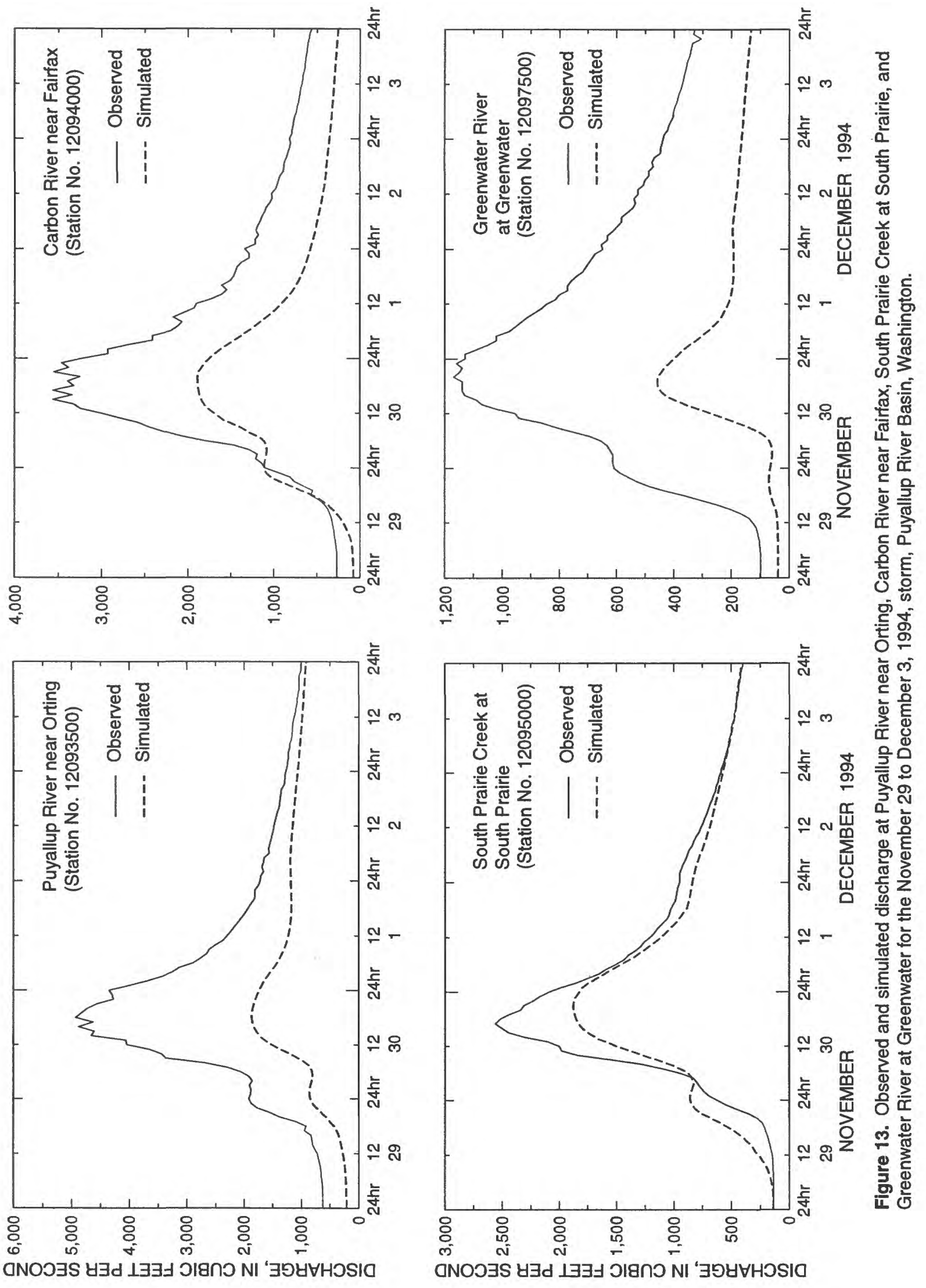


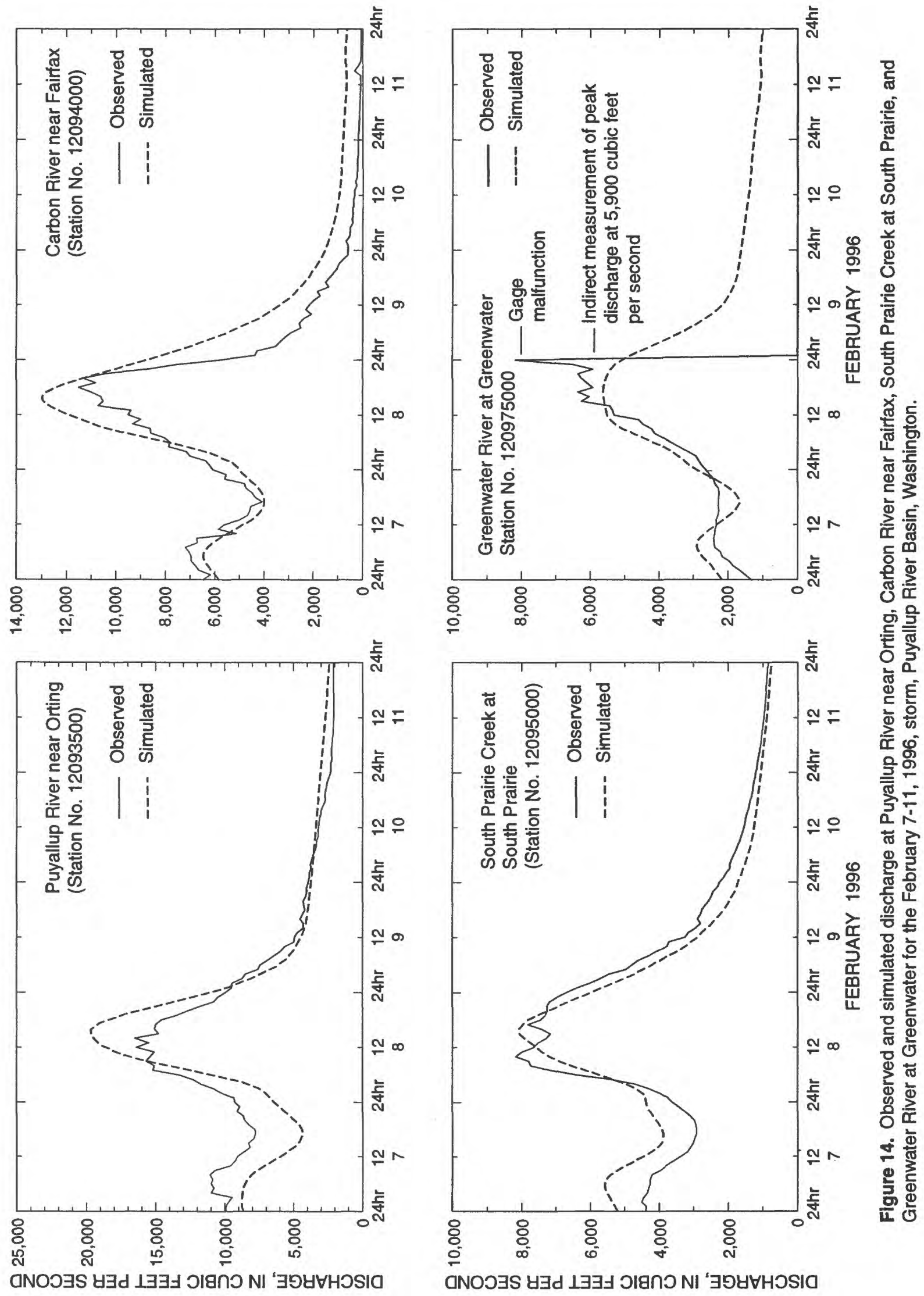


Table 11. Summation of errors of storm runoff and peak discharge for the five gaged subbasins in the Puyallup River Basin model, Washington

[RMSE, root mean square error; SEE, standard error of estimate]

\begin{tabular}{|c|c|c|c|c|}
\hline & \multicolumn{2}{|c|}{$\begin{array}{l}\text { Storm runoff volume, } \\
\text { in inches and (percent) }\end{array}$} & \multicolumn{2}{|c|}{$\begin{array}{l}\text { Peak discharge, in cubic feet } \\
\text { per second and (percent) }\end{array}$} \\
\hline & Calibration & Validation & Calibration & Validation \\
\hline Bias $^{1}$ (in percent) & $-0.29(-12.6)$ & $-0.51(-10.3)$ & $-112(-5.4)$ & $-385 \quad(6.0)$ \\
\hline $\mathrm{RMSE}^{2}$ (in percent) & $0.63(29.0)$ & $1.02(21.7)$ & $1,985(38.4)$ & $1,331(31.4)$ \\
\hline $\mathrm{SEE}^{3}$ (in percent) & 0.59 (27.6) & $0.94(20.2)$ & $2,092(40.1)$ & $1,349(32.6)$ \\
\hline
\end{tabular}

Storm runoff volume, in inches and (percent)

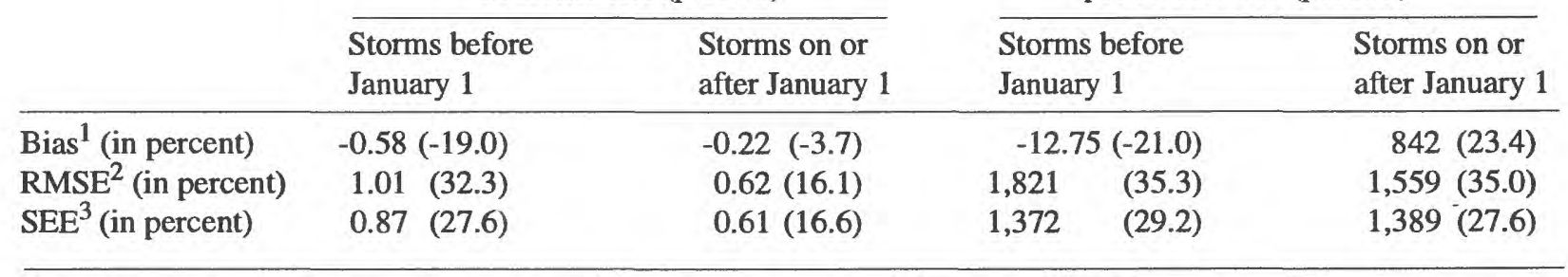

${ }^{1} \mathrm{Bias}=\sum_{i=1}^{n} \frac{S_{i}-O_{i}}{n} ; \mathrm{Bias}$, percent $=\left[\sum_{i=1}^{n} \frac{\left(\frac{S_{i}-O_{i}}{O_{i}}\right)}{n}\right] \times 100$

${ }^{2} \mathrm{RMSE}=$ Root mean square error $=\sqrt{\sum_{i=1}^{n} \frac{\left(S_{i}-O_{i}\right)^{2}}{n}}$

RMSE, percent $=100 \times \sqrt{\sum_{i=1}^{n} \frac{\left(\frac{S_{i}-O_{i}}{O_{i}}\right)^{2}}{n}}$

${ }^{3} \mathrm{SEE}=$ standard error of estimate $=\left(\frac{n}{n-1}\right) \times \sqrt{\mathrm{RMSE}^{2}-\mathrm{BIAS}^{2}}$

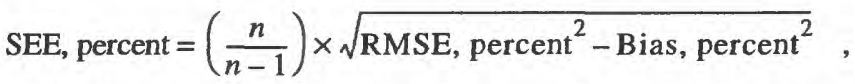

where $S$ is simulated value, $O$ is observed value, and $n$ is number of values.

Because precipitation varies greatly within 160-square-mile areas in the Puyallup River Basin, especially in the mid-to-upper elevations (fig. 5) where the fewest precipitation gages are located, there is the question whether snowband estimates of precipitation can be improved with additional precipitation gages. To answer this question, precipitation estimates for snowband 3
Peak discharge, in cubic feet per second and (percent) 
Nevan-McCullough and Buck Creek, are located only 3.6 miles apart in the same subbasin (fig. 3). The second pair of stations, Greenwater and Buck Creek, which are located 9.8 miles apart on either side of snowband 3 , are the two default stations that the Puyallup Flood-Alert System uses to compute the precipitation for snowband 3. The final pair of stations, Greenwater and Electron, are located 25.6 miles apart at similar elevations but separated by several ridges and river valleys. Eight-day precipitation totals were calculated for six storms when data were available. The Nevan-McCullough gage lies in snowband 3 of the upper White subbasin. In this analysis it is assumed that the precipitation of the Nevan-McCullough gage is the true precipitation for snowband 3 of the upper White subbasin and that the precipitation data obtained from the various pairs represent precipitation amounts that would be obtained from a precipitation network containing fewer and fewer stations.

The range in differences from the measured totals at Nevan-McCullough (table 12) is an indication of the accuracy that would be expected from increasing the density of precipitation gages. As expected, the Nevan-McCullough and Buck Creek pair, a pair representing what might be considered a maximum density of precipitation stations to estimate snowband precipitation, has the smallest range of differences (about 27 percent). The Greenwater and Buck Creek pair has about double the range in differences despite the fact that they straddle the snowband relatively close to one another. The Greenwater and Electron pair, which represents a relatively sparse network of gages, shows a large range of values-about three times the range of the Nevan-McCullough and Buck Creek pair. The test suggests that the accuracy of precipitation estimates can be increased by increasing the number of precipitation gages in the basin.

How well individual gages measure precipitation also affects how well precipitation over an area can be estimated. The manufacturer of some of the tipping-bucket gages used in this study specifies an accuracy of measurement within 4 percent of the true value at a rainfall rate of 2.2 inches per hour. More intense rates of rainfall generally result in larger errors, but intensities of rainfall in the Puyallup River Valley rarely exceed 2.2 inches per hourthe 2-year, 6-hour maximum precipitation for the midelevations of the Puyallup River Basin is about 1.6 inches (U.S. Department of Commerce, 1973). Often, a bigger problem with precipitation gages is that wind reduces the catch efficiency of a rain gage. However, most of the precipitation gages in this study were sheltered from the wind by trees, so wind should not have had a large effect. Larson and Peck (1974) showed that wind can reduce catch efficiency for rain about 1 percent for each mile per hour of wind velocity at the gage orifice. The reduction in catch efficiency of a shielded gage for snow is roughly double that for rain as wind increases, and of a non-shielded gage, it is more than triple. At the Nevan-McCullough site, a relatively windy location, paired heated tipping-bucket rain gages were placed side by side —one with an Alter shield and one without a shield. During 391 days of record, the shielded gage recorded 80.77 inches of precipitation while the unshielded gage recorded 79.15 inches, which is only 2.0 percent less.

Accurate simulation of SWE is dependent on accurate estimates of temperature and precipitation and correct calibration of the snow-related parameters. The errors in the simulated values of SWE are difficult to assess because there were little observed data available and the accuracy of the observed data was questionable. If more accurate observed SWE data were available, such as would be provided by a network of snow pillows within the basin or by improved and more frequent remote sensing of the basin, the calibration of the snow-related parameters probably could be improved. Also, if this observed data were available in real time, the simulated SWE values could be adjusted to agree with observed data just prior to a forecast model run. Improved simulation could be expected with the improved SWE estimates depending on the amount of snow-melt contributions to the flood.

Another possible source of error was the inaccuracy of the observed runoff volumes and peak discharges to which the models were calibrated. During floods, the accuracy of the observed streamflow record often is only fair ( 95 percent of the daily discharges are within 15 percent of the true discharge) to poor (daily mean discharges have less than fair accuracy) (Novak, 1985, p. 65). Because runoff volumes were computed from the mean daily discharges, the accuracy of these volumes probably is 15 percent or less. The errors in peak discharges obtained from gaging station records probably are greater than the error in mean daily discharges. Also, most of the peak-flow determinations for the February 8-9, 1996, flood were made indirectly and rated "fair"-indicating possible error in the range from 15 to 25 percent or greater (Benson and Dalrymple, 1967, p. 30).

The third source of error to be discussed is the deficiencies of the conceptual and SSARR models to represent the hydrologic process in the Puyallup River Basin. The model makes abstract, one-dimensional simplifications of the natural system in order to simulate runoff process using the limited amount of information describing the 
watershed. Model error can be expected to increase with each simplification of the natural system, but this must be balanced against having too complex a model. Too much information may add little to accuracy, while at the same time add excessive data requirements and parameters that will overload a modeling system designed for real-time use. For this project, the SSARR model seems to have the appropriate balance of complexity and simplicity to efficiently simulate the runoff process according to the conceptual model outlined earlier. For example, a lot of detail is provided to adjust the precipitation input, a major source of error, to subdivisions (snowbands) of a subbasin based on precipitation-elevation relations - the dominant factor affecting precipitation amounts in the basin. On the other hand, the SSARR model is less rigorous than other avail- able models in the details of the runoff process for different land types. For this project, even if a more "rigorous" model were needed, there is little discharge information available to calibrate the model according to different land types in the Puyallup River Basin. Also, this model deficiency is not crucial to the success of the simulations because the upper parts of the basin that contribute most to runoff consist of a relatively homogenous forested landscape or land type (although there are some differences in the degree of clearcutting). In addition, during major flood-producing storms in Western Washington, which are characterized by days and even weeks of preceding rain, the soils of all land types have generally reached or nearly reached their moisture holding capacity, and differences in peak runoff from different land types are less apparent.

Table 12. Observed storm precipitation totals at Nevan-McCullough Seed Orchard Meteorological site and estimated 8-day precipitation totals for snowband 3, subbasin UPWHT, calculated from three different pairs of precipitation stations

\begin{tabular}{|c|c|c|c|c|c|c|c|c|c|c|}
\hline \multirow{4}{*}{$\begin{array}{l}\text { Storm } \\
\text { number }^{2}\end{array}$} & \multirow{4}{*}{$\begin{array}{l}\text { Ob- } \\
\text { served }^{3}\end{array}$} & \multicolumn{9}{|c|}{ Station pairs ${ }^{1}$} \\
\hline & & \multicolumn{3}{|c|}{$\begin{array}{l}\text { Nevan-McCullough } \\
\text { and Buck Creek }\end{array}$} & \multicolumn{3}{|c|}{$\begin{array}{l}\text { Greenwater and } \\
\text { Buck Creek }\end{array}$} & \multicolumn{3}{|c|}{$\begin{array}{l}\text { Greenwater } \\
\text { and Electron }\end{array}$} \\
\hline & & \multirow{2}{*}{$\begin{array}{l}\text { Esti- } \\
\text { mated }^{4}\end{array}$} & \multicolumn{2}{|c|}{ Difference $^{5}$} & \multicolumn{3}{|c|}{ Difference $^{5}$} & \multirow{2}{*}{$\begin{array}{l}\text { Esti- } \\
\text { mated }^{4}\end{array}$} & \multicolumn{2}{|c|}{ Difference $^{5}$} \\
\hline & & & (inches) & (percent) & mated $^{4}$ & (inches) & (percent) & & (inches) & (percent) \\
\hline 1 & 6.67 & 6.72 & +0.05 & +0.78 & 6.51 & -0.16 & -2.35 & 7.09 & +0.42 & +6.28 \\
\hline 2 & 3.16 & 3.63 & +0.47 & +14.81 & 5.02 & +1.86 & +58.88 & 5.47 & +2.31 & +73.13 \\
\hline 3 & 3.26 & 3.33 & +0.73 & +2.08 & 3.73 & +0.47 & +14.36 & 4.22 & +0.96 & +29.45 \\
\hline 4 & 10.55 & 10.35 & -0.20 & -1.90 & 10.69 & +0.14 & +1.34 & 14.21 & +3.66 & +34.70 \\
\hline 5 & 2.70 & 2.38 & -0.32 & -11.97 & 2.86 & +0.16 & +5.95 & 3.80 & +1.10 & +40.85 \\
\hline 6 & 8.81 & 9.35 & +0.54 & +6.12 & 9.44 & +0.63 & +7.16 & 11.38 & +2.57 & +29.22 \\
\hline \multicolumn{3}{|c|}{ Range: } & 1.05 & 26.78 & & 2.02 & 61.23 & & 3.24 & 66.85 \\
\hline \multicolumn{11}{|c|}{$\begin{array}{l}{ }^{1} \text { Pair of stations used to estimate precipitation totals, full station names and number (in parenthesis) are listed below: } \\
\text { Greenwater-Greenwater River at Greenwater (12097500) } \\
\text { Buck Creek-Buck Creek Camp Meteorological Site near Greenwater (47011813121330800) } \\
\text { Electron-Puyallup River near Electron (12092000) } \\
\text { Nevan-McCullough-Nevan-McCullough Seed Orchard Meteorological site near Greenwater (470418121351200). }\end{array}$} \\
\hline${ }^{2}$ The & $\begin{array}{l}\text { dates for the } \\
\text { Storm No. } 1 \\
\text { Storm No. } 2 \\
\text { Storm No. } 3 \\
\text { Storm No. } 4 \\
\text { Storm No. } 5 \\
\text { Storm No. } 6\end{array}$ & $\begin{array}{c}\text { numbere } \\
10-27-9 \\
10-26-9 \\
02-15-9 \\
11-25-9 \\
01-04-9 \\
02-05-9\end{array}$ & $\begin{array}{l}\text { storms are } \\
4 \text { to } 11-03-9 \\
4 \text { to } 12-03-9 \\
5 \text { to } 02-22-9 \\
\text { to } 12-02-9 \\
5 \text { to } 01-11-9 \\
6 \text { to } 02-12-9\end{array}$ & $\begin{array}{l}\text { as follows: } \\
4 \\
4 \\
5 \\
5 \\
6 \\
6 .\end{array}$ & & & & & & \\
\hline \multicolumn{11}{|c|}{$\begin{array}{l}{ }^{3} \text { Observed 8-day precipitation total, in inches, for the shielded rain gage at Nevan-McCullough Seed Orchard Meteorological } \\
\text { site. }\end{array}$} \\
\hline \multicolumn{11}{|c|}{$\begin{array}{l}{ }^{4} \text { Estimated precipitation total, in inches, computed by the Puyallup River Basin model using indicated pair of precipitation } \\
\text { records. }\end{array}$} \\
\hline
\end{tabular}


A goal of the project was to minimize model errors while providing an efficient operational system to make flood simulations on a real-time basis. The SSARR model proved to have the flexibility and the appropriate algorithms to simulate peak discharges with some bias for the eight storms and require only two time series inputs-precipitation and temperature. Given the errors outlined above, the greatest opportunity to reduce error in this project and other similar projects appears to be the addition of more precipitation gages in the basin, especially in the midelevations (approximately 2,000 to 4,000 feet above sea level), where high precipitation rates ( 70 to 90 inches per year) and the high potential for snowmelt contributions to flood runoff are important for producing floods.

\section{Sensitivity Analysis of Precipitation and Temperature Inputs and Snow-water Equivalence on Simulated Discharge}

Three groups of simulations were performed to evaluate the effects of using precipitation inputs from different precipitation stations, of using different numbers of temperature station inputs, and of the accuracy of simulated snow-water equivalence on simulated runoff volumes and peak discharge.

\section{Influence of Precipitation Inputs on Simulated Results}

Rain-gage records frequently contain missing data or faulty data. The operational system for the Puyallup River Basin model has been set up to function when precipitation records from some sites are missing or unusable; however, different combinations of precipitation data will produce different simulated discharges. A test was made to show the effects on simulated discharges using regional (NWS-operated stations - some are outside the basin boundaries) and local (USGS-operated stations-all within the basin boundaries) precipitation inputs and different groupings of precipitation inputs from different precipitation stations. The tests were made using data from the two largest flood-producing storms in the 1996 water year. Six different combinations of precipitation inputs were used to simulate six sets of peak discharges and 5-day runoff volumes from the four upper subbasins where runoff was observed during two storms (table 13). In these simulations, subbasin precipitation was computed using equation 1. Precipitation weights were not used to adjust the computed subbasin average precipitation.
The sensitivity analysis showed that simulated peak discharge can be extremely sensitive to the precipitation inputs. Simulations using different regional or local pairs of precipitation inputs produce broad ranges of peak discharges and runoff volumes. These ranges are of similar magnitude to the errors obtained using the calibrated model. These results underscore the importance of having complete precipitation records, a dense network of rain gages, and heated tipping-bucket rain gages (or another cold temperature, precipitation-recording system) in the snow zone. Upgrading unheated rain gages in the current network for the Puyallup River Basin, especially those gages in the higher elevations, would produce a system that can accurately record precipitation when it is snowing.

\section{Influence of the Number of Temperature Inputs on Simulated Results}

Early in this study it was decided that four temperature stations would be used for the real-time runoff simulations instead of the seven available temperature stations. The smaller number of stations would lessen the data-input and data-checking requirements, and the stations not used were within the elevation range of the four stations that were used. It was believed that the addition of more temperature information would not significantly improve the estimation of lapse rates or the temperature distribution. A test comparing the simulated runoff using different sets and numbers of temperature stations was conducted to show how the number of temperature inputs affects simulation results. The test used the two largest runoff-producing storms during the data-collection period-the November 1995 storm and the February 1996 storm. Four sets of model runs using data from four sets of temperature stations were made (table 14). The Carbon temperature station had too much missing record during both storms to be used in this test.

The results of the temperature station sensitivity test indicated that errors in simulated peak discharge and runoff volume are larger when two temperature records are used than when four are used. All the error totals for model runs using Input 3 and Input 4 (which used only two temperature stations) were larger than the errors for the calibrated model (Input 1) except for one runoff volume total using Input 4. Also the individual peak discharges and runoff volumes for model runs using Input 3 and Input 4 differed significantly from each other, indicating that the model is sensitive to the pair of stations chosen as well as to the number of stations. There are insufficient numbers of stations to evaluate the effect on model accu- 
racy of increasing the number of temperature stations from four to six. However, the results in table 14 indicate that including more temperature stations would not significantly improve the accuracy of the calibrated model. While the results from Input 2 (six temperature stations used) showed some tendency to reduce the errors, the sum of the peak discharge errors for the February storm was about double the errors for the calibrated model.

\section{Influence of Simulated Snow-water Equivalence on Simulated Runoff}

An analysis of the importance of pre-storm SWE on simulated peak discharge and runoff volume was performed using data from only the February 1996 storm. The following three scenarios were tested: (1) assume zero SWE in the basin at the beginning of the day on February 5, 1996, the approximate beginning of the storm; (2) increase the simulated SWE in each elevation band by 30 percent on February 5; and (3) decrease the simulated SWE in each elevation band by 30 percent on February 5. To perform the tests, the calibrated watershed model was stopped on February 4 at midnight, and the SWE values were adjusted as described for the three scenarios. The model was restarted, run through the end of the day on February 8 , and the results were compared with the results of calibrated model run (table 15).

The results of these simulations of one storm in which snowmelt probably had a greater than average contribution to runoff showed that decreasing SWE has a much larger effect than increasing SWE (table 15). Increasing SWE by 30 percent increased simulated runoff volume and peak discharge by only 1.2 percent or less. Decreasing SWE by 30 percent and 100 percent (zero SWE) decreased simulated runoff volume by up to 5.7 and 12.9 percent, respectively, and decreased peak discharge by up to 5.6 and 11.2 percent, respectively. The effect of simulated SWE on simulated runoff volumes and peak discharges may be different for other storms, especially those storms during which snowmelt is not a major contribution to runoff.

\section{Model Limitations}

Because of the time and data constraints of this project, many of the hydrologic scenarios that are possible in the Puyallup River Basin were not observed or simulated, so several major limitations of the model are summarized here.
1. Only four water years of data (1994-97), the time period that the current network of gages has operated, were used to select eight storms for calibration and validation of the model. With more observed data, a larger range of conditions would be available to calibrate and test the model. Storms that have different precipitation totals, different initial snow extents, different temperature regimes, and other such variables may result in errors that fall outside the range of errors experienced during this calibration and validation.

2. Only one storm, February 1996 , had basin-wide estimates of snow-water equivalent available for calibration of the snow-related parameters; therefore, the calibration of these parameters was limited. Much more observed snow data or accurate estimates of snow-water equivalent would probably result in different and more reliable snow-related parameters for the simulation of snowmelt and accumulation.

3. The calibrations focused on two observed runoff statistics, peak-flow discharge and 5-day runoff volumes for major high-water events. Using the model to simulate baseflow or low flows or monthly and yearly water balances would not be valid within the error analysis provided. Glacial meltwater, which can comprise a major portion of summer flows, is not explicitly modeled.

4. The limited calibration of the river reaches was made with observed flows that were contained within the natural or man-made levees. The model cannot accurately simulate flows that breach levees, river banks, or dams.

5. No calibration or error analysis was done for the forecast model runs because the format, availability, and location of forecast points have changed several times throughout the life of this project. It has been shown that the accuracy and the number of precipitation inputs strongly influence the accuracy of the simulation of peak discharge and runoff volumes. The results of the real-time model using forecasted input data probably does not fall within the errors experienced during calibration and validation and would most likely have a larger range of errors. 
Table 13. Simulated discharge at four upper Puyallup subbasins, Washington, for two storms in water year 1996 using different combinations of precipitation inputs

[Precipitation inputs were computed using the stations listed below and the method described in the text section "Computation of Subbasin Precipitation."]

\begin{tabular}{|c|c|c|c|c|c|c|c|c|c|c|}
\hline \multirow[b]{4}{*}{ Subbasin } & \multicolumn{9}{|c|}{$\begin{array}{l}\quad \text { Regional precipitation inputs } \\
\text { (National Weather Service-operated stations) }{ }^{1}\end{array}$} & \\
\hline & \multicolumn{5}{|c|}{ Peak discharge, in cubic feet per second } & \multicolumn{5}{|c|}{ Runoff volume per unit area, in inches } \\
\hline & \multirow[b]{2}{*}{ Observed } & \multicolumn{3}{|c|}{ Simulated } & \multirow{2}{*}{$\begin{array}{l}\text { Percent } \\
\text { range }^{2}\end{array}$} & \multirow[b]{2}{*}{ Observed } & \multicolumn{3}{|c|}{ Simulated } & \multirow{2}{*}{$\begin{array}{l}\text { Percent } \\
\text { range }^{2}\end{array}$} \\
\hline & & Input 1 & Input 2 & Input 3 & & & Input 1 & Input 2 & Input 3 & \\
\hline \multicolumn{11}{|c|}{ Storm date: $11-27-95$ to $12-01-95$} \\
\hline Upper Puyallup & 13,600 & 8,740 & 8,280 & 12,200 & 28.8 & 7.24 & 4.28 & 5.11 & 5.07 & 11.5 \\
\hline Greenwater & 4,240 & 6,160 & 6,390 & 8,230 & 48.8 & 6.19 & 5.95 & 7.63 & 7.38 & 27.1 \\
\hline Carbon & 10,100 & 6,020 & 6,250 & 7,760 & 17.2 & 10.66 & 5.79 & 7.22 & 7.10 & 13.4 \\
\hline South Prairie & 4,860 & 4,460 & 4,950 & 6,030 & 32.3 & 5.21 & 5.36 & 6.66 & 6.22 & 25.0 \\
\hline \multicolumn{11}{|c|}{ Storm date: $02-07-96$ to $02-11-96$} \\
\hline Upper Puyallup & 18,300 & 19,600 & 13,200 & 17,200 & 35.0 & 7.38 & 6.07 & 5.54 & 5.91 & 7.2 \\
\hline Greenwater & 5,900 & 11,400 & 8,750 & 10,400 & 44.9 & 6.48 & 8.50 & 8.13 & 8.30 & 5.7 \\
\hline Carbon & 12,000 & 10,800 & 8,420 & 9,740 & 19.8 & 11.33 & 7.33 & 7.06 & 7.08 & 2.4 \\
\hline South Prairie & 8,170 & 9,270 & 7,290 & 8,150 & 24.2 & 7.83 & 7.80 & 7.26 & 7.73 & 6.9 \\
\hline
\end{tabular}

Local precipitation inputs

(U.S. Geological Survey-operated stations)

\begin{tabular}{|c|c|c|c|c|c|c|c|c|c|c|}
\hline \multirow[b]{3}{*}{ Subbasin } & \multicolumn{5}{|c|}{ Peak discharge, in cubic feet per second } & \multicolumn{5}{|c|}{ Runoff volume per unit area, in inches } \\
\hline & \multirow[b]{2}{*}{ Observed } & \multicolumn{3}{|c|}{ Simulated } & \multirow{2}{*}{$\begin{array}{l}\text { Percent } \\
\text { range }^{2}\end{array}$} & \multirow[b]{2}{*}{ Observed } & \multicolumn{3}{|c|}{ Simulated } & \multirow{2}{*}{$\begin{array}{l}\text { Percent } \\
\text { range }^{2}\end{array}$} \\
\hline & & Input 4 & Input 5 & Input 6 & & & Input 4 & Input 5 & Input 6 & \\
\hline \multicolumn{11}{|c|}{ Storm date: $11-27-95$ to $12-01-95$} \\
\hline Upper Puyallup & 13,600 & 7,780 & 11,300 & 7,320 & 29.3 & 7.24 & 5.54 & 5.60 & 5.09 & 7.0 \\
\hline Greenwater & 4,240 & 5,290 & 5,510 & 4,960 & 13.0 & 6.19 & 6.70 & 7.74 & 7.00 & 16.8 \\
\hline Carbon & 10,100 & 5,470 & 5,810 & 5,170 & 6.3 & 10.66 & 7.63 & 7.45 & 6.89 & 6.9 \\
\hline South Prairie & 4,860 & 4,390 & 6,110 & 4,490 & 35.4 & 5.21 & 7.26 & 7.24 & 6.67 & 11.3 \\
\hline \multicolumn{11}{|c|}{ Storm date: $02-07-96$ to $02-11-96$} \\
\hline Upper Puyallup & 18,300 & 19,800 & 11,900 & 18,800 & 43.2 & 7.38 & 7.08 & 6.06 & 6.59 & 13.8 \\
\hline Greenwater & 5,900 & 7,700 & 8,180 & 11,500 & 64.4 & 6.48 & 8.30 & 8.92 & 9.62 & 20.4 \\
\hline Carbon & 12,000 & 11,000 & 7,540 & 10,800 & 28.8 & 11.33 & 8.56 & 7.37 & 8.32 & 10.5 \\
\hline South Prairie & 8,170 & 9,610 & 6,650 & 9,390 & 33.5 & 7.83 & 9.05 & 8.10 & 8.60 & 12.1 \\
\hline $\begin{array}{r}\text { 1The normal } \\
\text { hown below in p } \\
\text { Input 1 } \\
\text { Input 2 } \\
\text { Input 3 } \\
\text { Input 4 } \\
\text { Input 5 } \\
\text { Input 6 }\end{array}$ & $\begin{array}{l}\text { annual preci } \\
\text { Irentheses: } \\
=\text { Seattle TC } \\
=\text { Mud Mour } \\
=\text { Seattle TC } \\
=\text { Buck Cree } \\
=\text { Buck Cree } \\
=\text { Greenwate }\end{array}$ & $\begin{array}{l}\text { pitation, in } \\
\text { OMA WSC } \\
\text { tain Dam a } \\
\text { OMA WSC } \\
k \text {, South Pr } \\
k \text { and Elect } \\
r \text { and South }\end{array}$ & $\begin{array}{l}\text { CMO AP } \\
\text { and Snoqu } \\
\text { CMO AP } \\
\text { rairie, Wh } \\
\text { tron, and } \\
\text { h Prairie. }\end{array}$ & $\begin{array}{l}\text { almie Pas } \\
\text { and Snoqu } \\
\text { te River C }\end{array}$ & $\begin{array}{l}\text { 03.16). } \\
\text { aie Pass. } \\
\text { al, Electro }\end{array}$ & $\begin{array}{l}\text { the Nationa } \\
\text { Dam (53.16 } \\
\text { and Greenw }\end{array}$ & $\begin{array}{l}1 \text { Weat } \\
\text { ater. }\end{array}$ & Servi & rat & ons are \\
\hline
\end{tabular}


Table 14. Simulated discharge at four upper Puyallup subbasins, Washington, for two storms in water year 1996 using different combinations of temperature inputs

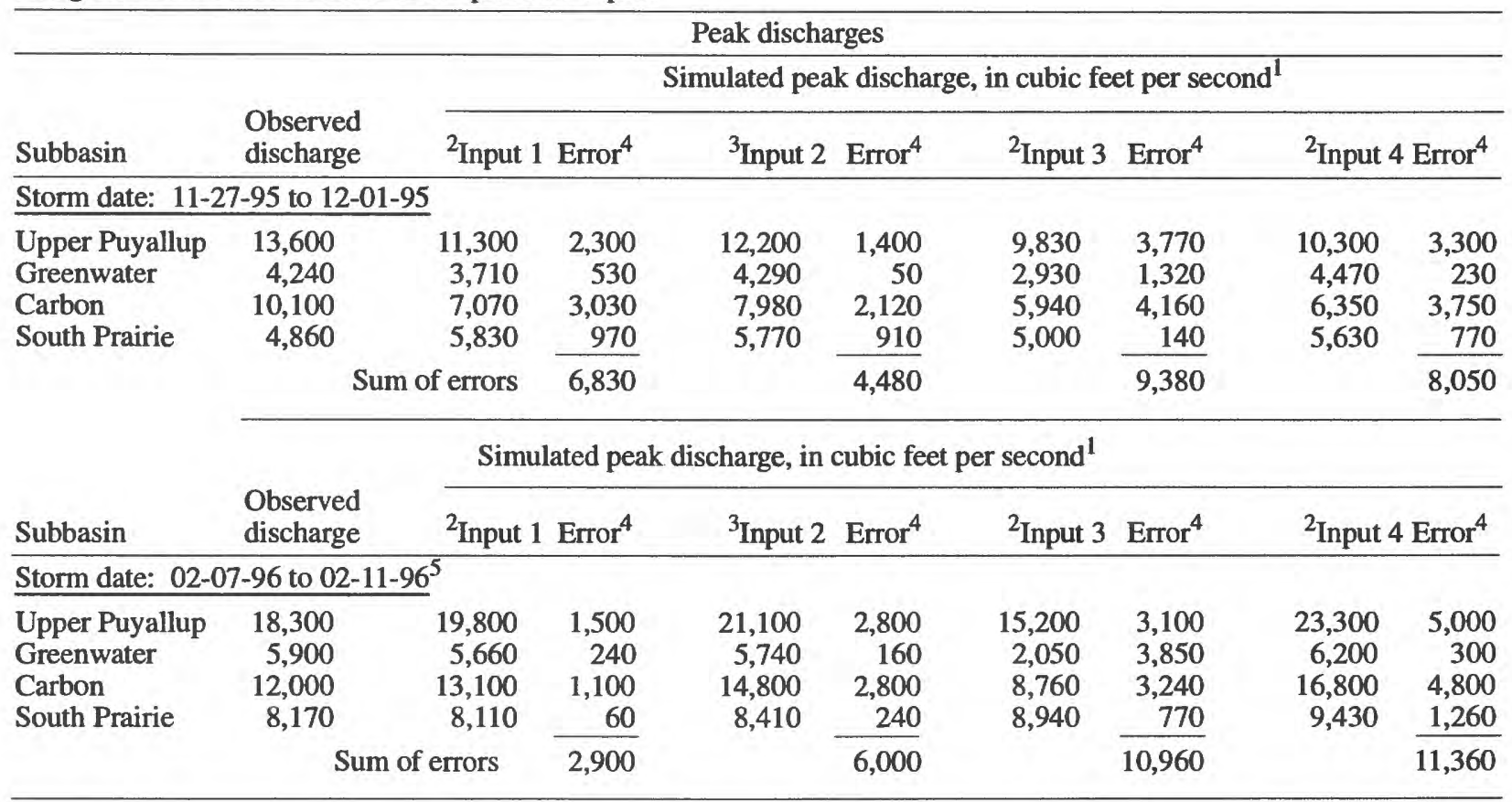

Runoff volumes

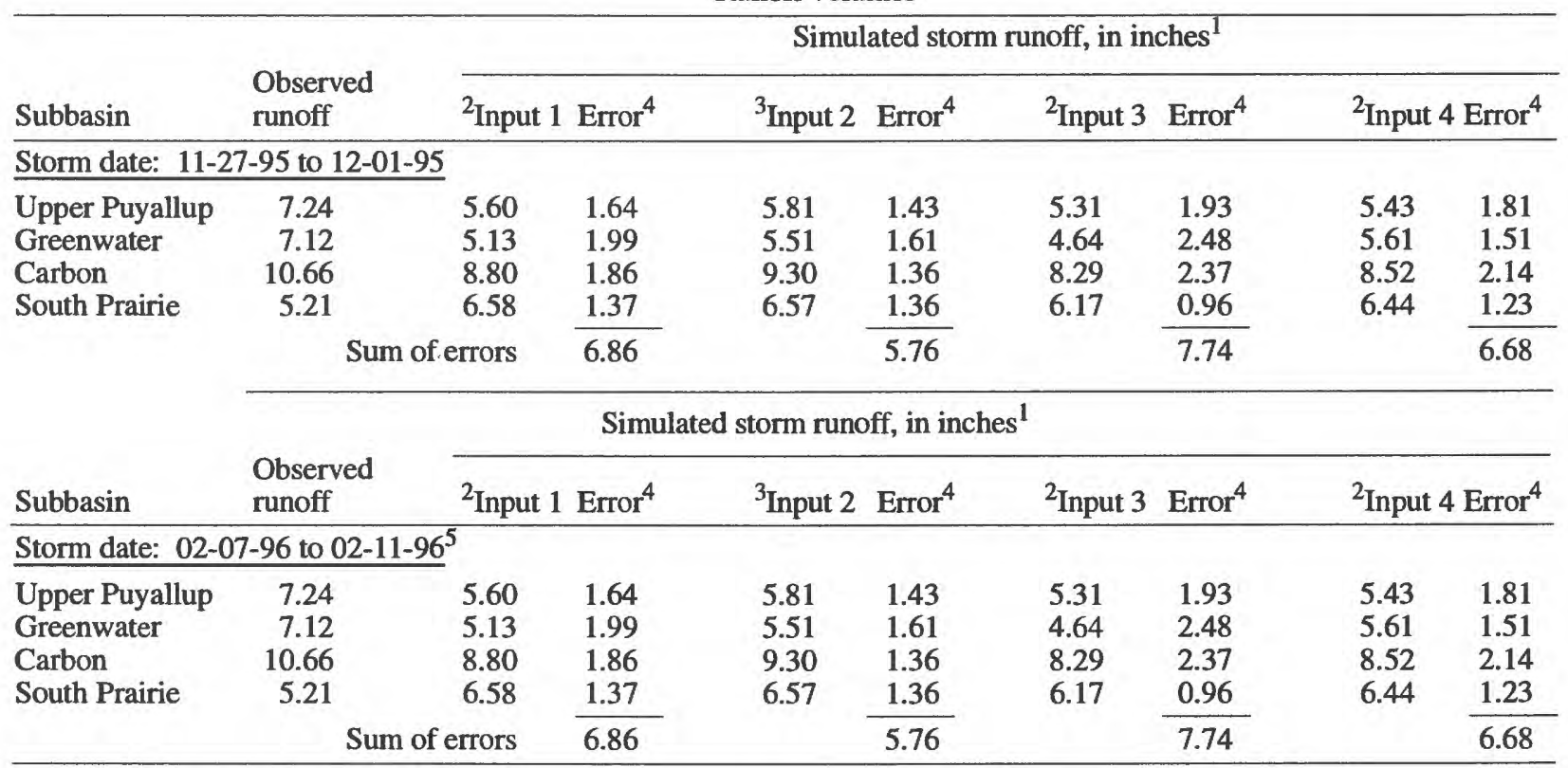

${ }^{1}$ Temperature stations used for the various input:

Input 1 = Electron, Cayuse Pass, South Prairie, and Buck Creek (calibrated model),

Input 2 = Electron, Cayuse Pass, South Prairie, Buck Creek, Greenwater, and White River Canal,

Input 3 = Electron and Buck Creek, and

Input 4 = South Prairie and Cayuse Pass.

${ }^{2}$ The matrixes that determine which pairs of temperature data sets to use to compute lapse rates and subbasin temperatures during a model run are defined in table 6 for input sets 1,3 , and 4.

${ }^{3}$ Input 2 used three temperature data sets to compute subbasin temperature using White River Canal as the third station for the upper Puyallup, South Prairie as the third station for the Carbon subbasin, and Greenwater as the third station for the Greenwater Basin.

${ }^{4}$ Error $=A B S(S-O)$,

where $A B S$ is the absolute value, $S$ is the simulated value, and $O$ is the observed value.

${ }^{5}$ The Electron temperature data were not used during the February storm because of missing data and were substituted with either the South Prairie or the Buck Creek data. 


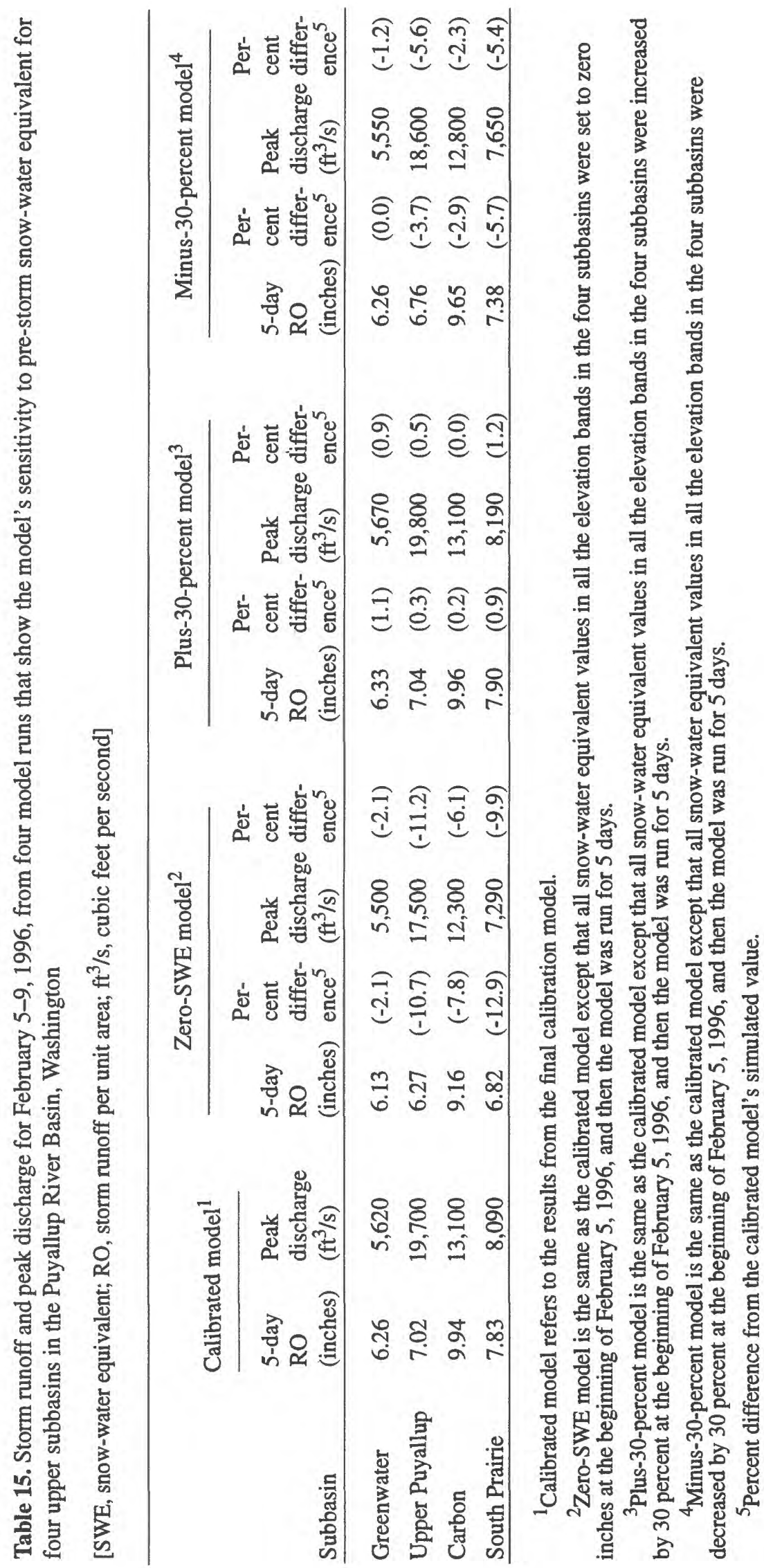




\section{REAL-TIME SIMULATION}

A main objective of this project was to build an operational model and data processing system capable of being operated by PCRI's personnel and of making real-time simulations of flood discharges and stages in the Puyallup River Basin. This section provides an overview of the Puyallup Flood-Alert System, a description of the general procedure users would follow to make a simulation, and an example of a real-time simulation.

\section{Overview of the Puyallup Flood-Alert System}

The Puyallup Flood-Alert System is composed of three parts: (1) the network of hydrologic and meteorologic gages and the accompanying data-telemetry and data-management system; (2) the computer interface (SSARRMENU) between PCRI personnel and numerical model (SSARR); and (3) the SSARR model, including its data-management component-the BULK file.

The Flood-Alert System begins in the field at the streamflow and meteorological gaging stations that provide the raw data for the system. Precipitation, temperature, river stage, and river discharge data are relayed to the USGS office in Tacoma by satellite telemetry every
4 hours during normal conditions and once every 15 minutes during alert mode. Data are received and stored on the USGS Washington District computer network and managed by the USGS Automated Data Processing System (ADAPS). Next, the data are transferred via telephone lines to a PC in the PCRI office as WATSTORE-formatted (National Water Data Storage and Retrieval System) files (fig. 2).

The computer interface, SSARRMENU, has several functions. First, it reviews data for values that have exceeded predetermined threshold values (table 16) and displays flashing alert symbols on a map display of the Puyallup River Basin (fig. 15). Second, it provides graphs of the available hydrologic and meteorologic data at user-selected stations and of simulated values of river stage and discharge. Third, it allows users to initiate a data transfer from the ADAPS system to the BULK file located on the PC, reformatting the data from WATSTORE format to SSARR format. During this data transfer, records of subbasin precipitation are created from the user-selected station precipitation records. And finally, SSARRMENU is a user interface to the SSARR model enabling users to make model runs easily.

Table 16. Threshold values for alert status for the Puyallup Flood-Alert System, Washington $\left[\mathrm{ft}^{3} / \mathrm{s}\right.$, cubic feet per second]

\begin{tabular}{|c|c|c|}
\hline Variable & Station name & Threshold value ${ }^{1}$ \\
\hline Stage & White River near Auburn & 80.0 feet \\
\hline Stage & Puyallup River at Alderton & 53.0 feet \\
\hline Discharge & Puyallup River at Puyallup & 17,000 \\
\hline Discharge & Puyallup River near Orting & 4,000 \\
\hline Stage & Carbon River at Orting & 27.0 feet \\
\hline Discharge & Carbon River near Fairfax & 3,500 \\
\hline Discharge & White River below Clearwater River & 7,090 \\
\hline Lake stage & Mud Mountain Lake & $1,092.0$ feet \\
\hline Stage & White River at Williams Bridge & 47.80 feet \\
\hline Discharge & South Prairie Creek & $2,500 \quad \mathrm{ft}^{3} / \mathrm{s}$ \\
\hline Stage & White River near Buckley & 7.10 feet \\
\hline Discharge & Greenwater River at Greenwater & $1,300 \quad \mathrm{ft}^{3} / \mathrm{s}$ \\
\hline 24-hour precipitation & Buck Creek Meteorological Site & 3.0 inches \\
\hline 6-hour precipitation & Buck Creek Meteorological Site & 1.4 inches \\
\hline
\end{tabular}

\footnotetext{
${ }^{1}$ If this value is exceeded, the station is on alert.
} 


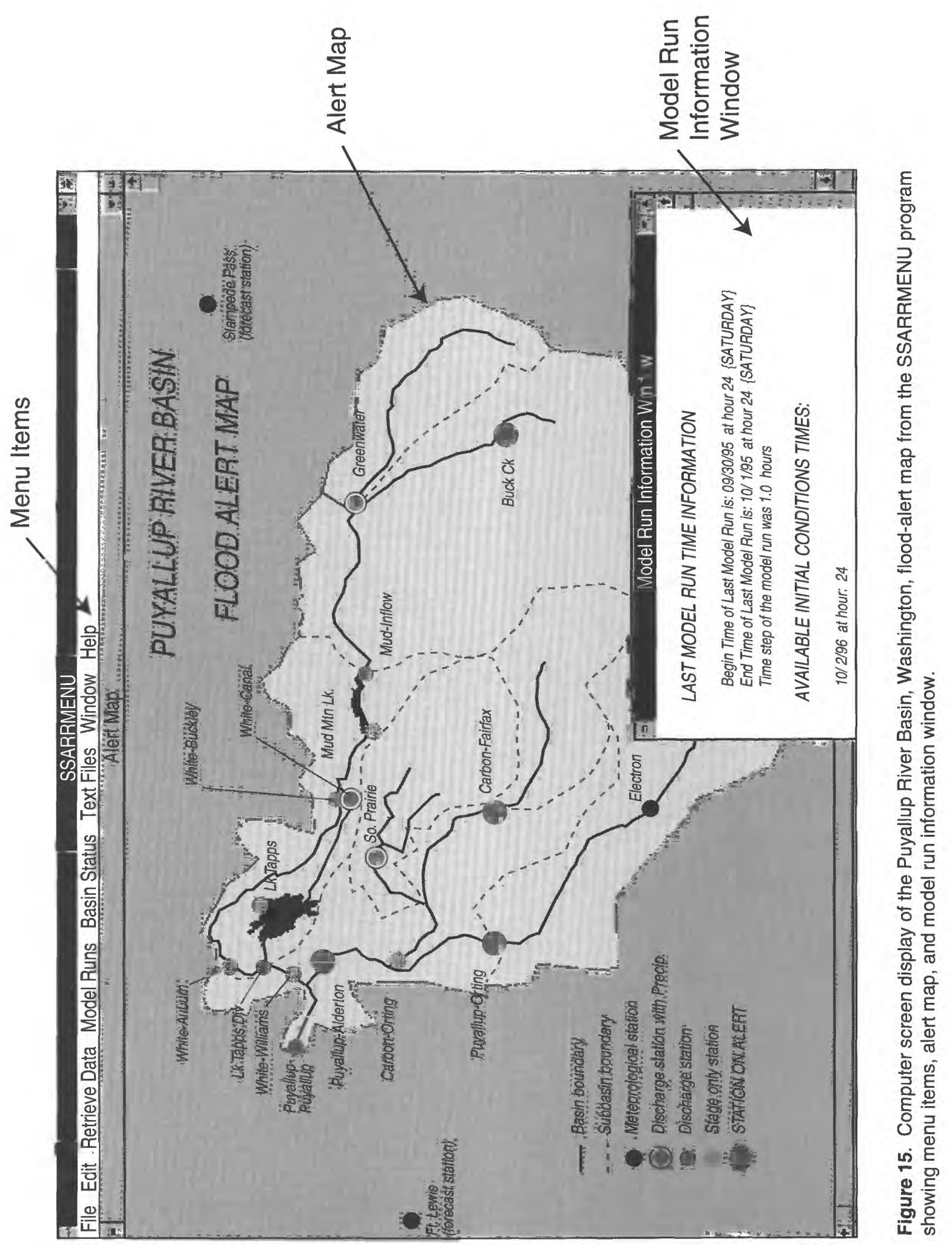




\section{User Interface for Real-time Simulation- SSARRMENU}

SSARRMENU is a FORTRAN90 computer program that provides a graphical interface for the Puyallup Flood-Alert System. It was written for a Microsoft Windows NT system and contains windows applications that include drop-down menus accessed with a mouse click, dialog boxes to solicit user input, graphical displays, and plotting routines for making time-series plots of observed and simulated data. A Microsoft MS-DOS and Windows 3.1 version of the program is also available. It operates in a similar manner, but uses a simple user interface composed of batch files and FORTRAN77 programs and the PLOTIODC program that is distributed with the PC version of SSARR for making time-series plots.

The Windows NT version of SSARRMENU contains several of the default Microsoft menus - file, edit, window, and help - that are common to many window-application programs and that allow users to exit the program, organize the windows, display information about the Microsoft menus, select text, select graphics, make prints of graphics and text, and so on. The remaining menus are related to running the Puyallup Flood-Alert System. Figure 16 is a schematic of these menus in the order they appear on the computer screen and a short description of their functions.

\section{General Procedure for using SSARRMENU}

To make model runs with SSARRMENU, users should follow the general order and procedures outlined below.

1. Initialize the model with the model characteristics and initial discharges in the simulated river reaches beginning on October 1 of the water year being modeled.

2. Retrieve data by telnet from the USGS computer. A Perl script is used to retrieve all the stage, discharge, temperature, and precipitation data from the ADAPS program as WATSTORE-formatted files. Users are prompted for the dates of the data retrieval and whether to use a 1-hour time step (storm mode) or a 6-hour time step (backup mode) between data values.

3. Convert the stage, temperature, and discharge data to SSARR-formatted files and load into the BULK file. Users are prompted by SSARRMENU to select the Mud Mountain Lake stage or the combined discharge of White River at Buckley and White River Canal at Buckley to simulate regulated outflow at Mud Mountain Lake. The program provides the option to produce time-series graphs of both sets of data before users need to make a choice.

4. Select precipitation stations that are deemed unusable and eliminate them from the data input. Station records of precipitation are converted into SSARRformatted subbasin records of precipitation and loaded into the BULK file. A program menu item is available for plotting the precipitation data in order to assess their quality.

5. Make a SSARR model run. The SSARRMENU program uses dialog boxes to prompt users for the begin time, the end time, the time-step, and the temperature records. The program makes a plot of the temperature time-series data so that users can assess the quality of the data before deciding to eliminate a temperature record. All model runs made after the first model run of the water year should begin exactly at the end time of a previous model run; the hydrologic state of the simulated watershed values and river-reach discharges are saved by the SSARR model for use as the initial conditions for the next model run. SSARRMENU provides a "Model Run Information Window" that gives the dates and times of the stored conditions at the ends of prior model runs.

6. Review the results of the simulation by making selected plots of the simulated data against available observed data or as text files of stage and discharge.

7. Run backup model runs (6-hour time step) periodically to keep the model current and determine if the simulations are significantly deviating from observed discharges. If a significant deviation is found, use an "adjust" model run with the 6-hour time step option to adjust user-selected subbasins. The adjust model run is made with the same start and end times as the last model run.

8. Adjust the simulated discharge values, if needed, to more closely agree with observed discharge values prior to making a forecast model run. If the simulated data do not produce a good match with the observed discharge, the initial conditions for the forecast model run may be in error. Typically, an "adjust" model run begins a day or two before the anticipated start time of the forecast model run and ends exactly on the start time of the forecast model run. Users are prompted for each of the five gaged subbasins that need adjustment, and then the 


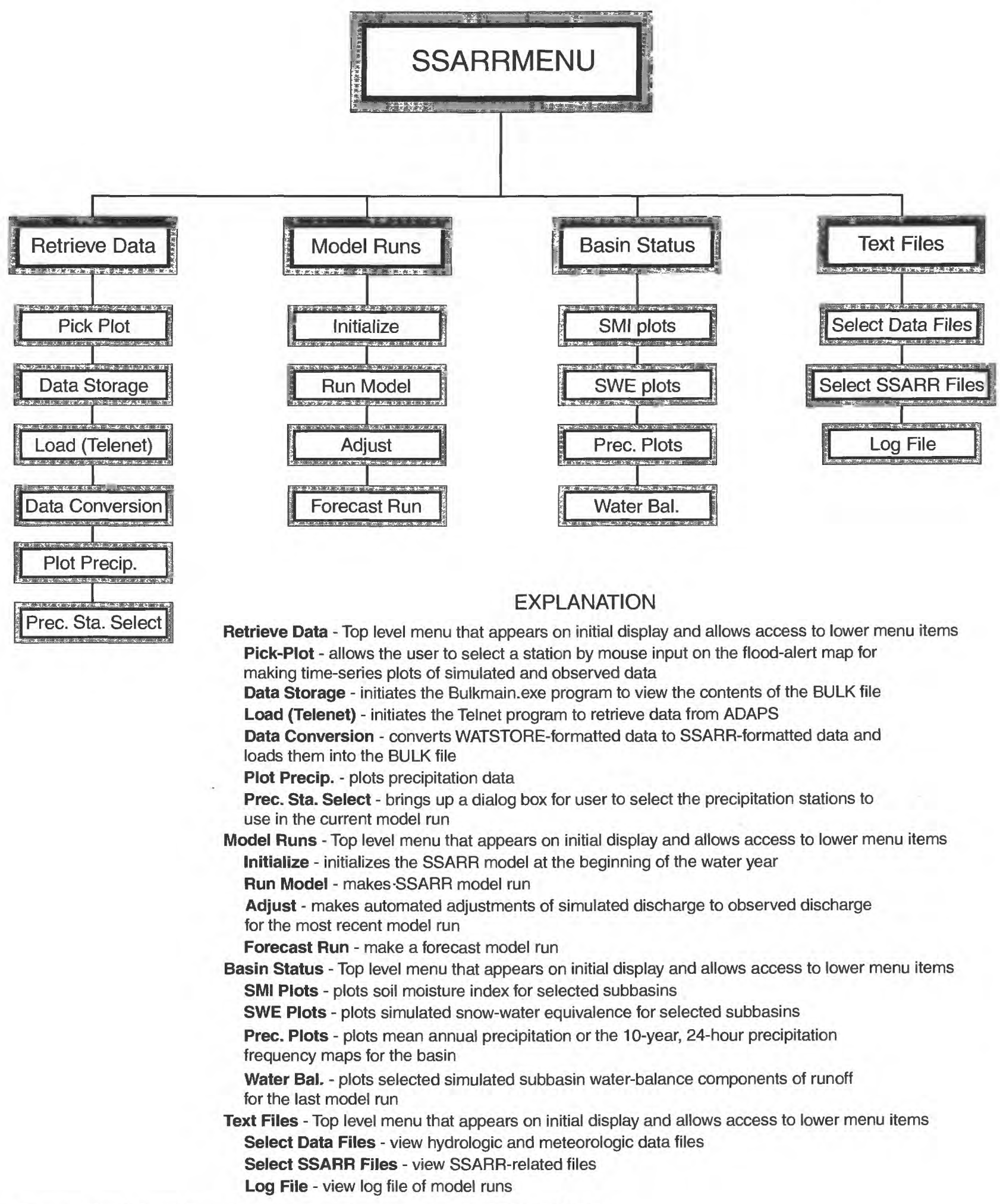

Figure 16. Schematic and description of menu items for SSARRMENU. 
automated adjustment procedures corrects the simulated hydrograph to agree with the observed hydrograph. At the end of the model run the hydrologic conditions of the basin are saved for use as the initial conditions of the forecast model run.

9. Download the quantitative temperature forecasts for Stampede Pass and Fort Lewis, the two nearest forecast points for the NWS meteorological forecast models, and the quantitative precipitation for Enumclaw, Ohanapecosh, and Stampede Pass from the NWS into the PC as three files into the data directory, SMP.WMO for the Stampede Pass temperature data, GRF.WMO for the Fort Lewis temperature data, and SEA.QPF for the precipitation data (table 17). These data are available at a 6-hour time step for 54 hours. SSARRMENU reformats the data, adjusts the characteristic file for the Puyallup River Basin model for the forecast data, and makes the forecast run with 6-hour time steps. Results are presented as time-series graphs of simulated hydrographs and as text files of discharge and stage.

\section{Example of a Real-Time Simulation}

Figure 17 provides results from a typical sequence of model runs in storm mode that demonstrate the automated adjust capability and the type of results that can be obtained for a forecast model run. Late in the day on December 31, 1996, the Puyallup River still had high flows from a recent peak flow on December 29, and the forecast for the next day was for more rain. There was serious concern that flooding would occur the next day, on January 1. Early on the New Year's Day, a model run was made, and the hydrograph for the upper Puyallup subbasin showed significant differences between the observed and simulated discharges (fig. 17, top hydrograph). Because it was known in advance that a forecast model run would be needed, the necessary precipitation and temperature data files were retrieved from the Seattle NWS office, and the start time for the forecast was noted. (In this example, forecasted precipitation for NWS station SeaTac was substituted for Fort Lewis, which was not available.) A model run begun at midnight on December 28 was ended on December 31 at 10:00 p.m., the time when the forecast data began, so that the model would store the initial conditions for the start of the forecast run. At this point the large discrepancy between the observed and simulated discharge at the end time signaled a need to make an adjustment for this particular subbasin. The model was rerun with the same start and end times, and the simulation was adjusted for the upper Puyallup River Basin (fig. 17, middle hydrograph). Since the simulation was underestimating discharge, the model automatically increased the amount of subbasin precipitation from 6.61 inches computed for the original model run to 8.48 inches for the adjust model run. The adjust run increased the simulated peak on December 29, which was already overestimating the observed peak; but the initial conditions for the forecast run were corrected to agree closely with the observed record late on December 31, and the forecast model run was given a much better starting point to more accurately forecast the peak flow on January 1 . In this case the forecast model run made a more accurate prediction of the peak discharge than a model run made after the flood, when actual precipitation recorded in the basin was used as model input (fig. 17, bottom hydrograph). The forecasted precipitation total at SeaTac Airport was 1.87 inches, and the observed rainfall for the same period was 2.33 inches (U.S. Department of Commerce, 1977). The forecasted precipitation total at Stampede Pass was 2.52 inches, but no observed precipitation data for Stampede Pass were available for this period for comparison. 
Table 17. Example of the quantitative precipitation file, SEA.QPF, and temperature forecast file, GRF.WMO, from the National Weather Service for use in the Puyallup River Basin model, Washington

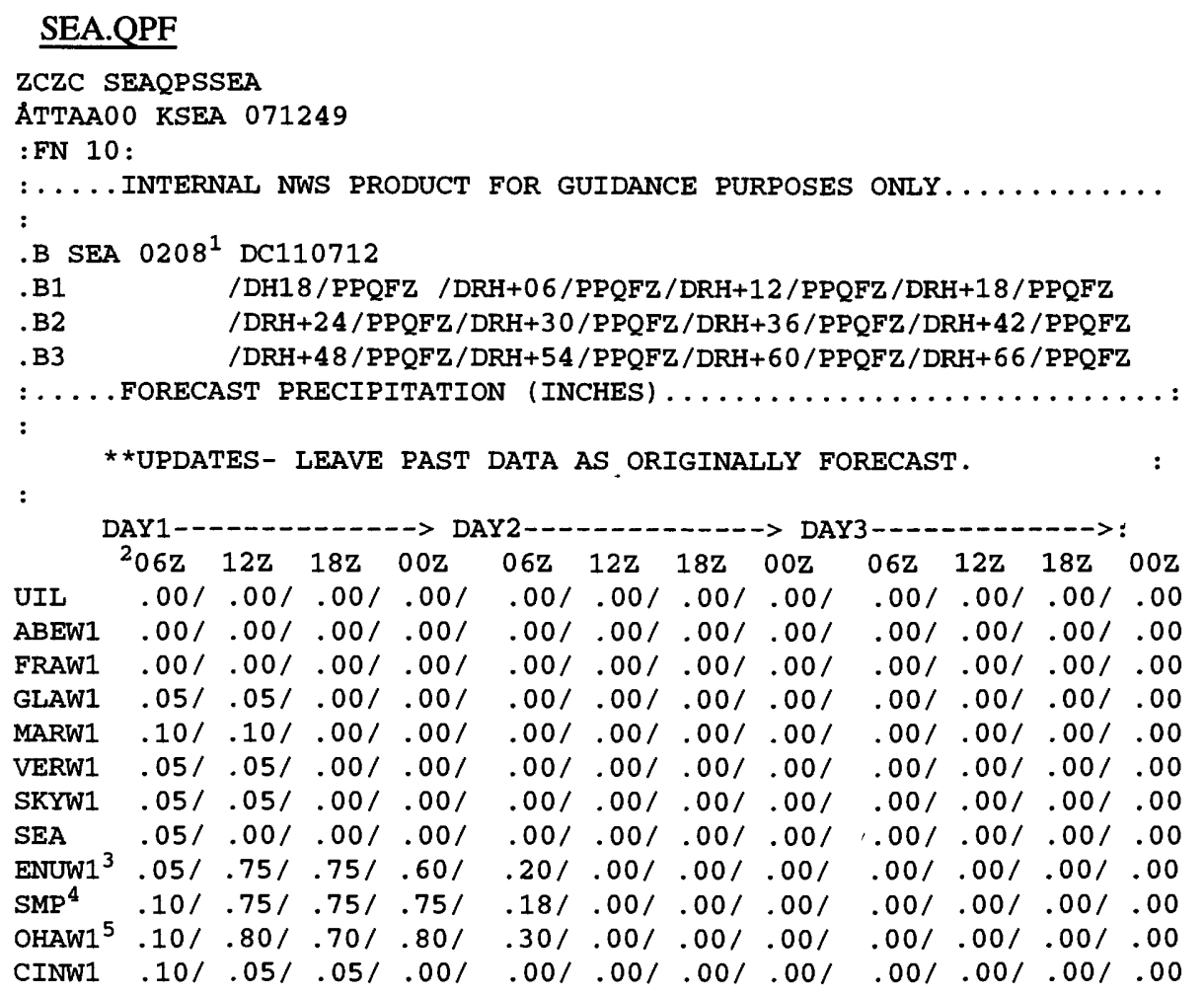

\section{GRF.WMO}

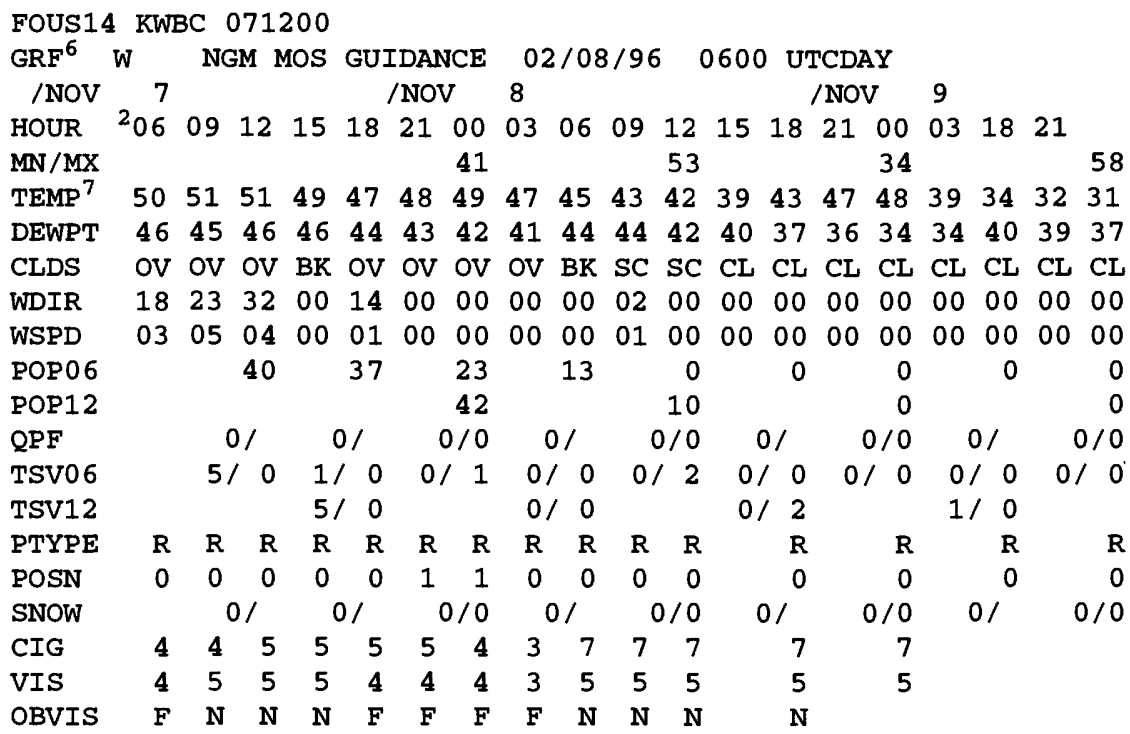

\footnotetext{
${ }^{1}$ Start date.

${ }^{2} 06 \mathrm{Z}$ or $06=6: 00$ a.m. (Greenwich Mean Time.)

${ }^{3} \mathrm{ENUW1}$ = quantitative precipitation forecast for Enumclaw.

${ }^{4} \mathrm{SMP} \quad=$ quantitative precipitation forecast for Stampede Pass.

${ }^{5} \mathrm{OHAW} 1$ = quantitative precipitation forecast for Ohanapecosh.

${ }^{6} \mathrm{GRF}=$ station code for Fort Lewis.

${ }^{7}$ TEMP $=$ forecasted air temperatures.
} 

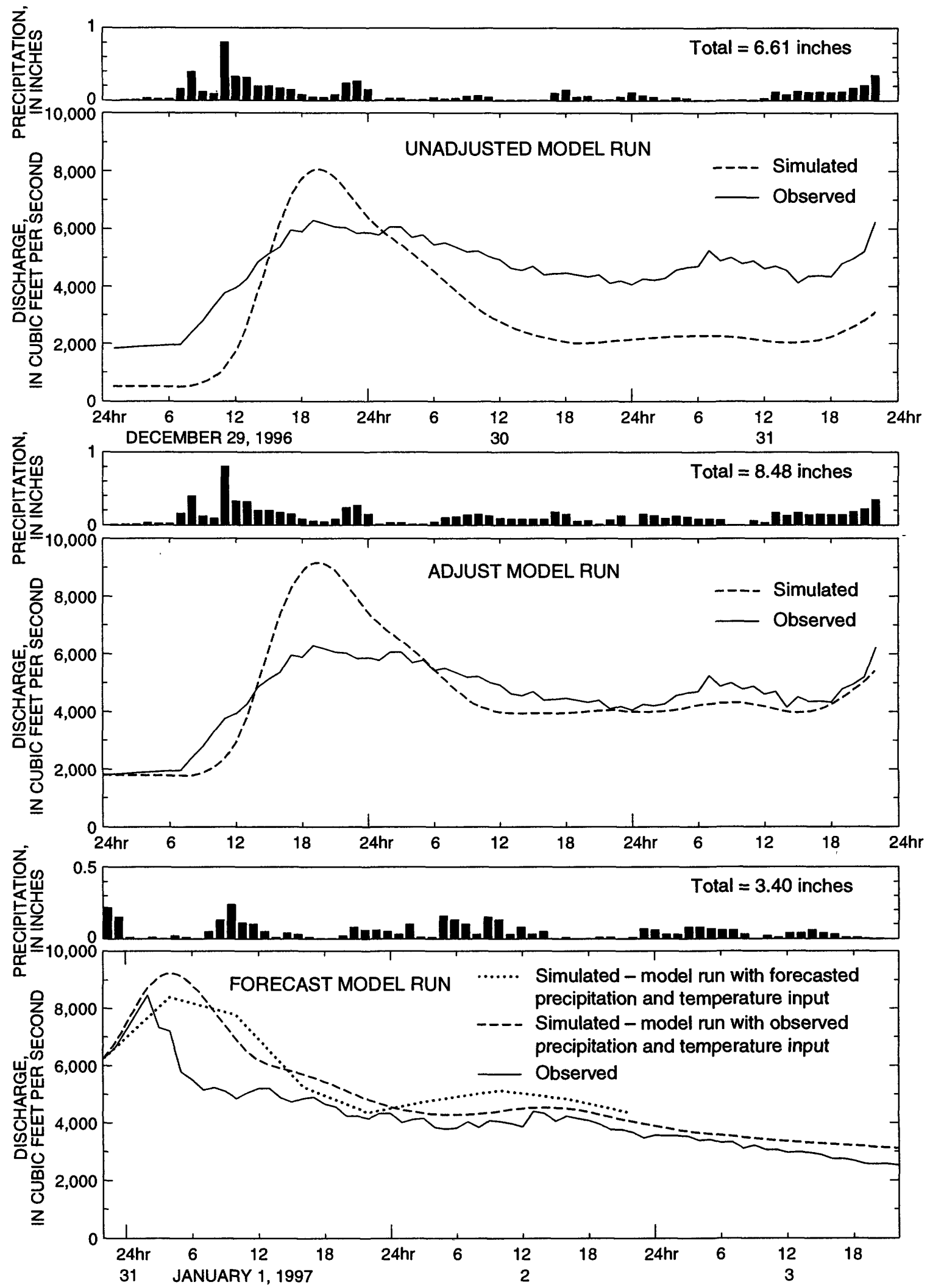

Figure 17. Simulated discharge and subbasin precipitation results from three model runs for the upper Puyallup subbasin in the Puyallup River Basin Model and observed discharge at Puyallup River near Orting, station number 12093500, Pierce County, Washington. 


\section{SUMMARY}

The U.S. Geological Survey (USGS), in cooperation with Pierce County River Improvement (PCRI) of the Pierce County Public Works and Utilities, has developed an operational system for determining flood-alert and flood-forecasting information for the Puyallup River Basin. The system consists of a network of USGS-operated river discharge and stage, precipitation, and temperature gages equipped with real-time telemetry; a numerical watershed and streamflow-routing model; and a computer interface that runs the model and displays the results and the flood-alert status. The system described in this report provides PCRI with options to obtain both current and 54-hour forecasts of river discharges and stages so that the agency can monitor impending flooding and deploy its resources to the highest priority potential problem areas at flood-control levees and other facilities that it is responsible for maintaining.

A conceptual model of flooding in the Puyallup River Basin, developed from observed meteorological conditions during the largest recorded peak flows, relies on five factors identified as important to the magnitude and timing of floods. (1) Topography strongly influences the precipitation totals, with precipitation generally increasing with increasing elevation. (2) Spatial patterns of precipitation totals for individual storms may vary from the pattern defined by annual totals. (3) Flooding is primarily associated with storms bringing heavy rain to the basin, but snowmelt also contributes to flooding. (4) The extent of snow cover and the freezing level during a storm are important factors in controlling snowmelt contributions to runoff. (5) Most soil moisture storage capacity must be filled before major flooding can occur.

The Streamflow Synthesis and Reservoir Regulation (SSARR) numerical watershed runoff and streamflowrouting model was chosen for this study because of its capability to make flood forecasts, its proven ability to simulate river flows in the Puyallup River Basin and other similar basins in the Pacific Northwest, its compatibility with personal computers, its ability to simulate streamflow regulation and diversions, and its ability to simulate floods according to the conceptual model of the Puyallup River Basin. The Puyallup River Basin was divided into seven subbasins or watersheds, each containing its own set of runoff parameters. Thirteen elevation bands further divided the Puyallup River Basin into snowbands, in which precipitation inputs are distributed according to user-defined relations between precipitation and elevation and temperature inputs are altered according to temperature lapse rates. An isohyet map of annual precipitation and a digital-elevation model were used to define average-annual subbasin precipitation and the relation hips between precipitation and elevation for each subbasin.

The SSARR model application was created from an existing National Weather Service (NWS) SSARF model application for the Puyallup River Basin by makir o alterations to accommodate a different version of the model that simulates snow accumulation and melt and a finer network of subbasins. Data from the current networl of stream gages during eight storms in the $1995,199^{\circ}$. and 1997 water years were used to calibrate (four storns) and validate (four storms) the numerical model. Durin \% one of the calibration storms (February 1996), peak discrarges at many gaging sites were the highest ever recorded at the gages. Geographic Information System coverages of snow-water equivalent (SWE) of the basin's snowpack were available before, during, and after the Februcry 1996 storm from the National Operational Hydrologic Pemote Sensing Center (NOHRSC). These coverages were found generally to underestimate SWE when compared to measurements at a few sites with snow pillows, especially at the high elevation sites, but they provided the only' basin-wide estimates available for comparison to simulated SWE from the Puyallup River Basin model.

Storm-volume-runoff and peak-discharge statistics were calculated for the five gaged subbasins in the upper portions of the basin for eight storms. Two-thirds of the simulated peak discharges for the calibration storn's were within 36 percent of the observed peak discharge, and two-thirds of the 5-day storm runoff volumes wer? within 17 percent of observed storm runoff volumes. For the validation storms, the corresponding values were 24 percent and 30 percent, respectively. There was a bias to undersimulate peak discharges despite calibration effor's to overcome this deficiency. A strong seasonal bias was detected, resulting in a -21.9 percent bias for all th o peaks that occurred before January 1 of the water year and a +23.4 percent bias for all peaks after January 1. Simulated SWE also showed a bias for the February 1996 sto'm. The SWE in the high-elevation zones was generally oversimulated, and in the lower-elevation zones, it was undersimulated. The midelevation zones were in general ag'eement with the NOHRSC estimates of SWE.

Tests using data from variously spaced precipitation stations to estimate precipitation at a particular lo:ation demonstrated the value of a relatively dense network of reliable precipitation stations. Gages that are hea ${ }^{+}$d so that they function during snowstorms are preferre-1. Tests of the model's sensitivity to number and location of precipitation stations used in the model produced rarges in 
simulated peak discharges and runoff volume equal in magnitude to the error in the calibrated model. Other sensitivity tests showed that the accuracy of the model increases when the number of temperature stations used in the model is increased from two to four. Simulations of one storm during which snowmelt contributed to runoff showed that peak discharge and runoff volume were more sensitive to underestimates than overestimates of prestorm SWE.

The computer program SSARRMENU is a user interface between the SSARR model and the real-time data inputs to and outputs from the model. The interface is used to access and obtain input data from ADAPS (a USGS data-base program), make the model runs customized for the Puyallup River Basin, display the results with time-series plots, and display the flood-alert status of selected stations where discharges have exceeded threshold values. Trials demonstrated the capabilities of the model to make 54-hour forecasts of discharge based on quantitative precipitation and temperature forecasts acquired from the NWS. The model's ability to simulate a wide range of flood peaks seen during the calibration and validation period and the Puyallup Flood-Alert System's customized interface for easy operation should greatly enhance PCRI's ability to quickly assess flooding potentials. However, the accuracy of the discharges that it simulates can be no better than the accuracy of both observed and forecasted precipitation inputs to the model.

\section{REFERENCES CITED}

Anderson, E.R., 1973, National Weather Service river forecast system - snow accumulation and ablation model: National Oceanic and Atmospheric Administration Technical Memorandum NWS HYDRO-17, 83 p.

Benson, M.A., and Dalrymple, Tate, 1967, General field and office procedures for indirect discharge measurements: U.S. Geological Survey Techniques of Water-Resources Investigation Book 3, Ch. A1, 30 p.

Harr, R.D., 1986, Effects of clearcutting on rain-on-snow runoff in western Oregon-a new look at old studies: Water Resources Research, v. 22, no. 7, p. 1095-1100.
Hartman, R.K., Rost, A.A., and Anderson, D.M., 1996, Spatial distribution of snow water equivalent observations in mountainous terrain: Chanhessen, Minn., National Operational Hydrologic Remote Sensing Center home page, on-line on the World Wide Web from URL http://www.nohrsc.nw:-gov/ html/papers/spatial/spatial.html, accessed March 26, 1996, HTML format.

Larson, L.W., and Peck, E.L., 1974, Accuracy of precipitation measurements for hydrologic modeling: Water Resources Research, v. 10, no. 4, p. 857-863.

Linsley, R.K., Jr., Kohler, M.A., and Paulhus, J.L.H., 1982, Hydrology for engineers (3rd ed.): New York, McGraw-Hill, 508 p.

Novak, Charles E., 1985, WRD data reports preprration guide: Reston, Va., U.S. Geological Survey 'Vater Resources Division, 199 p.

Schermerhorn, Vail P., 1967, Relations between topography and annual precipitation in Western Oregon and Washington: Water Resources Research, v. 3, no. 3, p. 707-711.

Soil Conservation Service [now the National Resource Conservation Service], 1965, [Map of] mear annual precipitation 1930-57 State of Washington: Portland, Oreg., Soil Conservation Service, 1 p.

U.S. Army Corps of Engineers, 1989, SSARR User manual supplement: Portland, Oreg., North Pacific Division, U.S. Army Corps of Engineers.

-1991, User manual SSARR model stream flow synthesis and reservoir regulation: Portland, Oreg., North Pacific Division, U.S. Army Corps of Engineers.

U.S. Department of Commerce, 1965-1996, Climatological data, Washington: National Oceanic and Atmospheric Administration, v. 69-100.

1973, Precipitation-frequency atlas of the western United States, Volume D-Washington: Silver Spring, Md., National Oceanic and Atmospreric Administration, NOAA Atlas 2, $43 \mathrm{p}$. 
1995, Climatological data annual summary, Washington: National Oceanic and Atmospheric Administration, v. 99, no. 13.

1997, Hourly precipitation data, Washington: National Oceanic and Atmospheric Administration, January 1997 , v. 47, no. 1 .
U.S. Geological Survey, 1987, Digital elevation models, data users guide 5: Reston, Va., U.S. Geolog: al Survey, $51 \mathrm{p}$.

Washington Department of Natural Resources, 1994, Washington State DEMs west: Olympia, Wa- $h$., CD-ROM, Arc/Info Grid format. 


\section{APPENDIX A. SSARR-CODE NAMES, CHARACTERISTICS FILE, AND TABLED CHARACTERISTICS}

The following includes a listing of the SSARR-code names for all the time series used in the model, a listing of the characteristic file for the final Puyallup River Basin model including the adjust REACH5 model (ADJRCH5) and the river stage ratings, and a listing of the tabled characteristics. The characteristic file, adjust REACH5 model, river stage ratings, and the tabled characteristics are use in conjunction with a job card and time-series data to make model runs with the SSARR model.

SSARR-code names for time series used in the Puyallup River Basin model

\begin{tabular}{llc} 
Subbasins & & \multicolumn{2}{c}{ Subbasin precipitation } \\
\cline { 3 - 3 } UPPUY & - Upper Puyallup River Subbasin & UPPP \\
LWPUY & - Lower Puyallup River Subbasin & LPUP \\
UPWHT & - Upper White River Subbasin & UPWP \\
LWWHT & - Lower White River Subbasin & LWHP \\
SOPRE & - South Prairie Creek Subbasin & SOPP \\
CARBON & - Carbon River Subbasin & CARP \\
GRNWTR & - Greenwater River Subbasin & GRNP \\
Observed precipitation & \\
\hline & BUCP & - Buck Creek. Camp Meteorological Site Station Number 470118121330800 \\
ELEP & - Puyallup River at Electron, Station Number 1209200 & \\
SOPR & - South Prairie Creek, Station Number 12095000 & \\
CARB & - Carbon River. near Fairfax, Station Number 12094000 & \\
WHTP & - White River Canal, Station Number 12099000 & \\
GNWP & - Greenwater River at Greenwater, Station Number 12097500 &
\end{tabular}

Observed temperature

$\begin{array}{ll}\text { BUCT } & \text { - Buck Creek Camp Meteorological Site } \\ \text { ELET } & \text { - Puyallup River at Electron } \\ \text { SPRT } & \text { - South Prairie Creek at South Prairie } \\ \text { CAYU } & \text { - Cayuse Pass Snow Pillows } \\ \text { GNWT } & \text { - Greenwater River at Greenwater } \\ \text { CART } & \text { - Carbon River near Fairfax }\end{array}$

Forecasted temperature

STMP - Stampede Pass

FTLT - Fort Lewis

Simulated discharge

UPPUY (basin outflow)

CARBON (basin outflow)

SOPRE (basin outflow)

GRNWTR (basin outflow)

SUM1Q (summation point)

MMDQ (reservoir outflow)

CANAL (CANALB outflow) SUM2Q (summation point TAPPSQ (reservoir outflow) PUYSIM (REACH5 outflow) PUYDIF (difference between PUYOBS and PUYSIM)
Observed discharge

ORTOBS - Puyallup River near Orting, Station Number 12093500

CRFOBS - Carbon River near Fairfax, Station Number 12094000

SOPOBS - South Prairie at South Prairie, Station Number 12095000

GRNOBS - Greenwater River at Greenwater, Station Number 12097500

WBCOBS - White River below Clearwater, Station Number 12097850

WNBOBS - White River near Buckley, Station Number 12098500 (not available for real-time)

WCBOBS - White River Canal at Buckley, Station Number 12099000

WBQOBS - White River at Buckley, Station Number 12100000

LTDOBS - Lake Tapps Diversion, Station Number 12101100

PUYOBS - Puyallup River at Puyallup, Station Number 12101500

MCQOBS - addition of flows (WCBOBS + WBQOBS)

WCQOBS - subtraction of flows (WBCOBS - GRNOBS) 
SSARR-code names for time series used in the Puyallup River Basin model--Continued

Simulated stage

ORSSIM (ORSSTG rating)

CRSSIM (CRSSTG rating)

PASSIM (PASSTG rating)

MMDE

WASSIM (WASSTG rating)

TAPPSE

PUSSIM (PUSSTG rating)

\section{Observed stage}

ORSOBS - Puyallup River near Orting, Station Number 12093500

CRSOBS - Carbon River at Orting, Station Number 12095690

PASOBS - Puyallup at Alderton, Station Number 12096500

MMDOBS - Forebay elevation, Mud Mountain Lake, Station Number 12098C?

WASOBS - White River near Auburn, Station Number 12100496

TAPOBS - Lake Tapps near Sumner, Station Number 12101000

PUSOBS - Puyallup River at Puyallup, Station Number 12101500 
ZC1 UPPUY UPPER_PUYALLUP_RIVER 169 SQ. MI.

NM, DA , SBND, NPS , TSS , NPSS, TSSS , NPBF , TSBF , NPLZ , TSLZ , BIITS, BIIMX, BFLIM, PBLZ , DGLIM

ZC2 UPPUY, $169,13,4,2.5,2,30 ., 3,60.2,1000 ., 36.2 .0, .05,0,0$,

NAME , EL-PT , SMR-CR, TIPMR, TIPM, RMR, PLWHC, SNETF , ELINT, LAPSE

ZC3 UPPUY, ELPUPU, MRCR, . 98, .84,.100,.03, .9,6000,3.3

NAME , SMI , BFP , S/SS , EKE, ETP , DKE , ETMO

ZC4 UPPUY, SM21, BI79, SS07, KE04, ETPPUY, DKE, ETM

NAME , TINTMX, BASE, PXTEMP, PMIN , PMAX, GMLT , ETI PCT, WEMIN, WEPCT, WEMAX

ZC5 UPPUY, $.2,32,34, .017, .033$, GMLT, ETIPCT $, 2,60, .4$

NAME, MRPCT, OBS-STA

ZC6 UPPUY, MRPCT, ORTOBS

NAME, ELEV1, AREA1, ELEV2, AREA2, ELEV3, AREA3, ETC .

ZCP UPPUY, $0,0.0,500,0.9,1000,11.9,1500,18.6,2000,35.6,2500,47.1,3000,54.9,3500$,

ZCP UPPUY, $61.6,4000,69.6,4500,78.2,5000,84.5,6000,90.8,8000,96.5,15000,100.0$

NAME, PERCENT-AREA1, PERCENT-AREA2, PERCENT-AREA3, ETC FOR EACH BAND

ZCA UPPUY, $0.9,11.0,6.7,17.0,11.5,7.8,6.7,8.0,8.6,6.3,6.3,5.7,3.5$

INITIAL CONDITIONS: (IF DATE MISSING, START TIME FROM T CARD USED) SURFACE

NAME , TIME-DATE , FLOW-PHS1, FLOW-PHS2 , FLOW-PHS3, ETC .

Z2S UPPUY, , 1, 5, 10, 20

SUBSURFACE

NAME , TIME-DATE , FLOW-PHSS1, FLOW-PHSS2 , FLOW-PHSS3 , ETC.

Z2SS UPPUY, , 20, 20

BASEFLOW

NAME , TIME-DATE , FLOW-PHBF1, FLOW-PHBF2 , FLOW-PHBF3, ETC.

Z2B UPPUY, , $100,100,100$

LOWERZONE

NAME, TIME-DATE, FLOW

Z2LZ UPPUY, , 200, 200

SNOWBANDS

NAME , TIME , ROP , BFP , CC , SLIQW, ATIMR, ATICC , WE , SMI , BII , TINT

Z201 UPPUY, , , , 0, 0, 60,0,0.0, 2.0,0,.1

Z202 UPPUY, , , $0,0,60,0,0.0,2.0,0, .1$

Z203 UPPUY, , , $0,0,55,0,0.0,2.0,0, .1$

Z204 UPPUY, , , $0,0,50,0,0.0,2.0,0, .1$

Z205 UPPUY, , , , 0, 0, 45, 0, 0.0,2.0,0,.1 
Z206 UPPUY, , , , 0, 0,40,0,0.0,2.0,0,.1

$\mathrm{Z} 207$ UPPUY, $, \ldots, 0,0,35,0,0.0,2.0,0, .1$

$\mathrm{Z} 208$ UPPUY, , , , 0, 0, 30, 0, 0.0,2.0,0,.1

Z209 UPPUY, , , , 0, 0, 25, 0, 0.0,2.0,0,.1

Z210 UPPUY, , , , 0, 0, 20,0,0.0,2.0,0,.1

Z211 UPPUY, , , 0, 0,15,0,2.0,2.0,0,.1

Z212 UPPUY, , , $0,0,10,0,5.0,2.0,0, .1$

Z213 UPPUY, , , $0,0,5,0,20.0,2.0,0, .1$

HYDROMET STATIONS

BASIN NAME, DATA CODE, STA. NAME, WEIGHT, DATA CODE, STA. NAME, WEIGHT, ETC .

ZCH UPPUY, 4 , ELET , 100, 4, CAYU, 100, 3, UPPP , 100

ZC1 SOPRE SOUTH_PRAIRIE_CREEK_BASIN

NM, DA, SBND , NPS , TSS , NPSS , TSSS , NPBF , TSBF , NPLZ , TSLZ , BIITS , BI IMX, BFLIM, PBLZ , DGLII*

ZC2 SOPRE, $90.2,11,3,3.0,3,6 ., 2,40 ., 2,1000 ., 36 ., 2.0, .05,0,0$,

NAME , EL-PT, SMR-CR, TIPMR, TIPM, RMR, PLWHC, SNETF, ELINT, LAPSE

ZC3 SOPRE, ELPSOP, MRCR, .98, .84,.100,.03,.9,6000,3.3

NAME , SMI, BFP , S/SS , EKE , ETP , DKE , ETMO

ZC4 SOPRE, SM17, BI79, SS81, KE04, ETPMMD, DKE, ETM

NAME, TINTMX, BASE, PXTEMP, PMIN , PMAX, GMLT, ETIPCT, WEMIN, WEPCT, WEMAX

ZC5 SOPRE, .2, 32, 34, .017, .033, GMLT, ETIPCT, 2, 60, .4

NAME, MRPCT, OBS-STA

ZC6 SOPRE, MRPCT, SOPOBS

NAME , ELEV1, AREA1, ELEV2 , AREA2 , ELEV3, AREA3, ETC .

ZCP SOPRE, 0, 0.0,500, .7,1000,17.4,1500,31.7,2000,51.1,2500,64.1,3000,74.0

ZCP SOPRE, 3500,82.2,4000,89.6,4500,95.3,5000,98.8,6000,100.0

NAME, PERCENT-AREA1, PERCENT-AREA2, PERCENT-AREA3, ETC FOR EACH BAND

ZCA SOPRE, . 7, 16.7,14.3,19.4,13.0,9.9, 8.2, 7.4, 5.7, 3.5,1.2

INITIAL CONDITIONS: (IF DATE MISSING, START TIME FROM T CARD USED)

SURFACE

NAME , TIME-DATE, FLOW-PHS1, FLOW-PHS2 , FLOW-PHS3, ETC .

Z2S SOPRE, , 1, 5, 10

SUBSURFACE

NAME , TIME-DATE , FLOW-PHSS1, FLOW-PHSS2 , FLOW-PHSS3 , ETC .

Z2SS SOPRE, , 10,10,10

BASEFLOW

NAME, TIME-DATE , FLOW-PHBF1, FLOW-PHBF2 , FLOW-PHBF3, ETC .

Z2B SOPRE, , 50,50

LOWERZONE

NAME, TIME-DATE, FLOW

Z2LZ SOPRE, , 0, 0 


\section{SNOWBANDS}

NAME , TIME , ROP , BFP , CC , SLIQW, ATIMR, ATICC , WE , SMI , BII , TINT

Z201 SOPRE, , , , 0, 0,60,0,0.0,2.0,0,.1

Z202 SOPRE, , , 0, 0,60,0,0.0,2.0,0,.1

Z203 SOPRE, , , 0, 0,55,0,0.0,2.0,0,.1

Z204 SOPRE, , , 0,0,50,0,0.0,2.0,0,.1

Z205 SOPRE, , , , 0, 0,45,0,0.0,2.0,0,.1

Z206 SOPRE, , , $0,0,40,0,0.0,2.0,0, .1$

Z207 SOPRE, , , , 0, 0,35,0,0.0,2.0,0,.1

Z208 SOPRE, , , , 0, 0,30,0,0.0,2.0,0,.1

Z209 SOPRE, , , $0,0,25,0,0.0,2.0,0, .1$

Z210 SOPRE, , , , 0, 0, 20,0,0.0,2.0,0,.1

Z211 SOPRE, , , 0, 0, 15, 0,2.0,2.0,0,.1

HYDROMET STATIONS

BASIN NAME, DATA CODE, STA. NAME, WEIGHT, DATA CODE, STA. NAME, WEIGHT, ETC.

ZCH SOPRE, 4, SPRT, 100, 4, ELET , 100, 3, SOPP, 85

ZC1 CARBON CARBON_RIVER_BASIN

NM , DA, SBND , NPS , TSS, NPSS , TSSS , NPBF , TSBF , NPLZ , TSLZ , BIITS , BIIMX, BFLIM, PBLZ , DGLIM

ZC2 CARBON , 80.0,11, 3, 3.0,3,6.,2,40.,2,1000.,36.,2.0, .05,0,0,

NAME , EL-PT , SMR-CR, TIPMR, TIPM, RMR, PLWHC, SNETF , ELINT, LAPSE

ZC3 CARBON, ELPCRB, MRCR3 $, .98, .84, .200, .03, .9,6000,3.3$

NAME , SMI , BFP , S/SS , EKE, ETP, DKE, ETMO

ZC4 CARBON, SM21, BI79, SS81, KE04, ETPMMD, DKE, ETM

0 NAME , TINTMX, BASE, PXTEMP , PMIN , PMAX, GMLT , ETIPCT , WEMIN , WEPCT , WEMAX

ZC5 CARBON, .2, 32, 34, .017, .033, GMLT, ETIPCT, 2,60, .4

NAME, MRPCT, OBS-STA

ZC6 CARBON, MRPCT, CRFOBS

NAME, ELEV1, AREA1, ELEV2, AREA2, ELEV3, AREA3, ETC.

ZCP CARBON, $1000,0.0,1500,2.2,2000,10.7,2500,18.8,3000,28.1,3500,38.7,4000,50.5$

ZCP CARBON, 4500,63.2,5000,75.0,6000,89.2,8000,96.3,16000,100.0

ZCA CARBON, $2.2,8.5,8.1,9.3,10.6,11.8,12.7,11.8,14.2,7.1,3.7$

INITIAL CONDITIONS: (IF DATE MISSING,START TIME FROM T CARD USED)

SURFACE

NAME , TIME-DATE, FLOW-PHS1, FLOW-PHS2 , FLOW-PHS3 , ETC .

Z2S CARBON, , 1, 5, 10

SUBSURFACE

NAME , TIME-DATE , FLOW-PHSS1, FLOW-PHSS2, FLOW-PHSS3 , ETC .

Z2SS CARBON, , 10, 10,10

BASEFLOW

NAME, TIME-DATE, FLOW-PHBF1, FLOW-PHBF2 , FLOW-PHBF3 , ETC.

Z2B CARBON, , 50, 50 
LOWERZONE

NAME , TIME-DATE, FLOW

Z2LZ CARBON, , 100,100

SNOWBANDS

NAME , TIME, ROP , BFP , CC , SLIQW, ATIMR, ATICC , WE, SMI , BII , TINT

$\mathrm{Z} 201$ CARBON, , , $0,0,55,0,0.0,2.0,0, .1$

Z202 CARBON, , , , 0, 0, 50,0,0.0,2.0,0,.1

Z203 CARBON, , , , 0, 0, 45, 0, 0.0,2.0,0,.1

Z204 CARBON, , , , 0, 0, 40,0,0.0,2.0,0,.1

Z205 CARBON, , , , 0, 0, 35, 0, 0.0,2.0,0,.1

$\mathrm{Z} 206$ CARBON, , , , 0, 0, 30, 0, 0.0, $2.0,0, .1$

Z207 CARBON, , , , 0, 0, 25,0,0.0,2.0,0,.1

Z208 CARBON, , , , 0, 0, 20,0,0.0,2.0,0,.1

Z209 CARBON, , , , 0, 0, 15, 0,2.0,2.0,0,.1

Z210 CARBON, , , , 0, 0, 10,0,5.0,2.0,0,.1

Z211 CARBON, , , , 0, 0, 5, 0,20.0,2.0,0,.1

HYDROMET STATIONS

BASIN NAME, DATA CODE, STA. NAME, WEIGHT, DATA CODE, STA.NAME, WEIGHT, ETC .

ZCH CARBON, 4, ELET , 100, 3, CARP, 120

ZC1 LWPUY LOWER_PUYALLUP_RIVER_BASIN

NM, DA , SBND, NPS, TSS, NPSS, TSSS, NPBF , TSBF , NPLZ , TSLZ , BIITS, BIIMX, BFLIM, PBLZ , DGLIN:

ZC2 LWPUY, $129,8,4,10 ., 3,10 ., 3,60.2,1000,36.2 .0, .05,0,0$,

NAME , EL-PT, SMR-CR, TIPMR, TIPM, RMR, PLWHC, SNETF , ELINT, LAPSE

ZC3 LWPUY, ELPLPU, MRCR3, .98, .84, .200, .03, .9, 6000, 3.3

NAME, SMI , BFP , S / SS , EKE, ETP , DKE, ETMO

ZC4 LWPUY, SM17, BI31, SS80, KE03, ETPPUY, DKE, ETM

NAME , TINTMX, BASE , PXTEMP , PMIN , PMAX, GMLT , ETIPCT , WEMIN, WEPCT , WEMAX

ZC5 LWPUY, . 2, 32, 34, .017, .033, GMLT, ETIPCT, 2, 60, .4

NAME, MRPCT, OBS-STA

ZC6 LWPUY, MRPCT

NAME, ELEV1, AREA1, ELEV2 , AREA2 , ELEV3 , AREA3 , ETC .

ZCP LWPUY, $0,0.0,500,41.0,1000,72.1,1500,79.5,2000,88.0,2500,95.1,3000,98.9$,

ZCP LWPUY, $3500,99.9,4000,100.0$

ZCA LWPUY, $41.0,31.1,7.4,8.5,7.1,3.8,1.0,0.1$

INITIAL CONDITIONS: (IF DATE MISSING, START TIME FROM T CARD USED)

SURFACE

NAME, TIME-DATE, FLOW-PHS1, FLOW-PHS2 , FLOW-PHS3, ETC.

Z2S LWPUY, , 1, 2, 5, 10

SUBSURFACE

NAME , TIME-DATE , FLOW-PHSS1, FLOW-PHSS2 , FLOW-PHSS3 , ETC .

Z2SS LWPUY, , 5, 5, 10 


\section{BASEFLOW}

NAME, TIME-DATE, FLOW-PHBF1, FLOW-PHBF2, FLOW-PHBF3, ETC.

Z2B LWPUY, , 10, 10, 10

LOWERZONE

NAME, TIME-DATE, FLOW

Z2LZ LWPUY, , 0,0

\section{SNOWBANDS}

NAME , TIME , ROP , BFP , CC , SLIQW, ATIMR, ATICC , WE , SMI , BII , TINT

Z201 LWPUY, , , $0,0,60,0,0.0,2.0,0, .1$

Z202 LWPUY, , , $0,0,60,0,0.0,2.0,0, .1$

Z203 LWPUY, , , , 0, 0, 55, 0, 0.0,2.0,0,.1

Z204 LWPUY, , , $0,0,50,0,0.0,2.0,0, .1$

Z205 LWPUY, , , $0,0,45,0,0.0,2.0,0, .1$

Z206 LWPUY, , , , 0, 0,40,0,0.0,2.0,0,.1

Z207 LWPUY, , , 0, 0,35,0,0.0,2.0,0,.1

Z208 LWPUY, , , , 0, 0,30,0,0.0,2.0,0,.1

HYDROMET STATIONS

BASIN NAME, DATA CODE, STA. NAME, WEIGHT, DATA CODE, STA. NAME, WEIGHT, ETC.

ZCH LWPUY, 4, SPRT, 100, 3, LPUP , 100

ZC1 GRNWTR GREENWATER_RIVER_BASIN

NM, DA, SBND, NPS , TSS , NPSS , TSSS , NPBF , TSBF , NPLZ , TSLZ , BIITS , BIIMX, BFLIM, PBLZ , DGLIM

ZC2 GRNWTR, 75.8,9,4,2.5,2,30.,3,60.,2,1000.,36.,2.0, 05, 0, 0,

NAME , EL-PT , SMR-CR, TIPMR, TIPM, RMR, PLWHC, SNETF , ELINT, LAPSE

ZC3 GRNWTR, ELPGWT, MRCR3, .98, .84,.100,.03,.9, 6000, 3.3

NAME, SMI , BFP , S/SS, EKE, ETP, DKE, ETMO

ZC4 GRNWTR, SM17, BI37, SS80, KE03, ETPMMD, DKE, ETM

NAME , TINTMX, BASE, PXTEMP , PMIN , PMAX, GMLT , ETIPCT , WEMIN, WEPCT , WEMAX

ZC5 GRNWTR, . 2, 32, 34, .017, .033, GMLT, ETIPCT, 2, 60, .4

NAME, MRPCT, OBS-STA

ZC6 GRNWTR, MRPCT, GRNOBS

NAME , ELEV1, AREA1, ELEV2, AREA2 , ELEV3 , AREA3 , ETC.

ZCP GRNWTR, 1000,0.0,1500,3.2,2000,10.0,2500,20.7,3000,34.1,3500,50.6,4000,69.1,

ZCP GRNWTR, 4500,84.1,5000,99.0,6000,100.0,8000,100.0

ZCA GRNWTR, 3.2,6.8,10.7,13.4,16.5,18.5,15.0,14.9,1.0

INITIAL CONDITIONS: (IF DATE MISSING, START TIME FROM T CARD USED)

SURFACE

NAME , TIME-DATE, FLOW-PHS1, FLOW-PHS2 , FLOW-PHS3, ETC.

Z2S GRNWTR, 1, $1,10,10$

SUBSURFACE

NAME , TIME-DATE , FLOW-PHSS1, FLOW-PHSS2, FLOW-PHSS3, ETC.

Z2SS GRNWTR, , 10,10 


\section{BASEFLOW}

NAME , TIME-DATE , FLOW-PHBF1, FLOW-PHBF2, FLOW-PHBF3 , ETC.

Z2B GRNWTR, , 50, 50,50

LOWERZONE

NAME, TIME-DATE, FLOW

Z2LZ GRNWTR, , 0, 0

SNOWBANDS

NAME , TIME , ROP , BFP , CC , SLIQW, ATIMR, ATICC , WE , SMI , BII, TINT

Z201 GRNWTR, , , , 0, 0, 50, 0, 0.0, 2.0,0, .1

Z202 GRNWTR, , , , 0, 0, 45,0,0.0,2.0,0,.1

Z203 GRNWTR, , , , 0, 0, 40,0,0.0,2.0,0,.1

Z204 GRNWTR, , , , 0, 0, 35, 0, 0.0,2.0,0,.1

Z205 GRNWTR, , , 0, 0, 30,0,0.0,2.0,0,.1

Z206 GRNWTR, , , , 0, 0, 25,0,0.0,2.0,0,.1

Z207 GRNWTR, , , , 0, 0, 20,0,0.0,2.0,0,.1

Z208 GRNWTR, , , , 0, 0, 15, 0,2.0,2.0,0,.1

Z209 GRNWTR, , , , 0, 0, 10, 0, 5.0,2.0,0,.1

HYDROMET STATIONS

BASIN NAME, DATA CODE, STA.NAME, WEIGHT, DATA CODE, STA.NAME, WEIGHT, ETC.

ZCH GRNWTR, 4, BUCT , 100, 3, GRNP , 75

ZC1 UPWHT UPPER_WHITE_RIVER_BASIN

NM, DA , SBND, NPS, TSS , NPSS, TSSS , NPBF , TSBF , NPLZ , TSLZ , BIITS, BIIMX, BFLIM, PBLZ , DGLIM

ZC2 UPWHT, 299, 11, 4, 2.5,2,30. 3,60.,2,1000.,36.,2.0, .05, 0, 0,

NAME , EL-PT, SMR-CR, TIPMR, TIPM, RMR, PLWHC, SNETF, ELINT, LAPSE

ZC3 UPWHT, ELPUWT, MRCR, . 98, .84,.100, .03, .9,6000,3.3

NAME , SMI , BFP , S/SS, EKE , ETP , DKE , ETMO

ZC4 UPWHT, SM21, BI37, SS80, KE03, ETPMMD, DKE, ETM

NAME , TINTMX, BASE , PXTEMP, PMIN, PMAX, GMLT , ETIPCT , WEMIN, WEPCT, WEMAX

ZC5 UPWHT, . 2, 32, 34, .017, .033, GMLT, ETIPCT, 2, 60, .4

NAME, MRPCT, OBS-STA

ZC6 UPWHT, MRPCT, WCQOBS

NAME , ELEV1, AREA1, ELEV2 , AREA2 , ELEV3 , AREA3 , ETC .

ZCP UPWHT, $1000,0,1500,1.6,2000,6.8,2500,14.8,3000,25.2,3500,36.7$

ZCP UPWHT, $4000,48.5,4500,60.7,5000,70.8,6000,88.1,8000,97.80,15000,100.0$

ZCA UPWHT, $1.6,5.2,8.0,10.4,11.5,11.8,12.2,10.1,17.3,9.7,2.2$

INITIAL CONDITIONS: (IF DATE MISSING, START TIME FROM T CARD USED)

SURFACE

NAME , TIME-DATE , FLOW-PHS1, FLOW-PHS2 , FLOW-PHS3 , ETC.

Z2S UPWHT, , 1, 5, 20,50

SUBSURFACE

NAME , TIME-DATE , FLOW-PHSS1, FLOW-PHSS2, FLOW-PHSS3 , ETC.

Z2SS UPWHT, , 20, 20 


\section{BASEFLOW}

NAME, TIME-DATE , FLOW-PHBF1, FLOW-PHBF2 , FLOW-PHBF3, ETC .

$\mathrm{Z} 2 \mathrm{~B}$

UPWHT, , 100, 100, 100

LOWERZONE

NAME, TIME-DATE, FLOW

Z2LZ UPWHT, , 200,200

\section{SNOWBANDS}

NAME , TIME , ROP , BFP , CC , SLIQW, ATIMR, ATICC , WE, SMI , BII , TINT

Z201 UPWHT, , , 0, 0, 55, 0, 0.0,2.0,0,.1

Z202 UPWHT, , , $0,0,50,0,0.0,2.0,0, .1$

Z203 UPWHT, , , , 0, 0, 45, 0, 0.0,2.0,0,.1

Z204 UPWHT, , , , 0, 0, 40,0,0.0,2.0,0,.1

Z205 UPWHT, , , , 0, 0, 35, 0, 0.0,2.0,0,.1

Z206 UPWHT, , , 0, 0,30,0,0.0,2.0,0,.1

Z207 UPWHT, , , , 0, 0,25,0,0.0,2.0,0,.1

Z208 UPWHT, , , 0, 0, 20,0,0.0,2.0,0,.1

Z209 UPWHT, , , , 0, 0, 15, 0,2.0,2.0,0,.1

Z210 UPWHT, , , , 0, 0, 10,0,5.0,2.0,0,.1

Z211 UPWHT, , , , 0, 0, 5, 0, 20.0,2.0,0,.1

HYDROMET STATIONS

BASIN NAME, DATA CODE, STA. NAME, WEIGHT, DATA CODE, STA. NAME, WEIGHT, ETC .

ZCH UPWHT, 4, BUCT , 100, 4, CAYU, 100, 3, UPWP, 100

ZC1 LWWHT LOWER_WHITE_RIVER_BASIN

NM, DA, SBND , NPS , TSS , NPSS , TSSS , NPBF , TSBF , NPLZ, TSLZ , BIITS , BIIMX, BFLIM , PBLZ , DGLIM

ZC2 LWWHT, 106, 10,4,10. 3, 10. 3,60.,2,1000.,36.,2.0, .05, 0, 0,

NAME, EL-PT , SMR-CR, TIPMR, TIPM, RMR, PLWHC, SNETF , ELINT, LAPSE

ZC3 LWWHT, ELPLWT, MRCR3 $, .98, .84, .200, .03, .9,6000,3.3$

NAME , SMI , BFP , S/SS , EKE, ETP , DKE , ETMO

ZC4 LWWHT, SM17, BI31, SS80, KE03, ETPPUY, DKE, ETM

NAME , TINTMX, BASE, PXTEMP , PMIN, PMAX, GMLT , ETIPCT , WEMIN, WEPCT , WEMAX

ZC5 LWWHT, .2, 32, 34, .017, .033, GMLT, ETIPCT, 2, 60, .4

NAME, MRPCT, OBS-STA

ZC6 LWWHT, MRPCT

NAME , ELEV1, AREA1, ELEV2 , AREA2 , ELEV3, AREA3 , ETC .

ZCP LWWHT , 0, 0, 500,15.0,1000,59.1,1500,73.8,2000,81.7,2500,87.0,3000,92.0

ZCP LWWHT, $3500,96.0,4000,98.2,4500,99.6,5000,100.0$

ZCA LWWHT, 15.0,44.1,14.7,7.9,5.3,5.0,4.0,2.2,1.4,0.4

INITIAL CONDITIONS: (IF DATE MISSING, START TIME FROM T CARD USED) SURFACE

NAME, TIME-DATE , FLOW-PHS1, FLOW-PHS2 , FLOW-PHS3 , ETC.

Z2S LWWHT, , 1, 2, 5, 10 
SUBSURFACE

NAME, TIME-DATE, FLOW-PHSS1, FLOW-PHSS2, FLOW-PHSS3 , ETC .

Z2SS LWWHT, , 5, 5, 10

BASEFLOW

NAME , TIME-DATE , FLOW-PHBF1, FLOW-PHBF2 , FLOW-PHBF3 , ETC.

Z2B LWWHT, , 10, 10, 10

LOWERZONE

NAME, TIME-DATE, FLOW

Z2LZ LWWHT, , 0, 0

SNOWBANDS

NAME , TIME , ROP , BFP , CC, SLIQW, ATIMR, ATICC, WE, SMI , BII , TINT

Z201 LWWHT, , , 0, 0,60, 0, 0.0, 2.0,0,.1

Z202 LWWHT, , , , 0, 0,60,0,0.0,2.0,0,.1

Z203 LWWHT, , , $0,0,55,0,0.0,2.0,0, .1$

Z204 LWWHT, , , $0,0,50,0,0.0,2.0,0, .1$

$\mathrm{Z} 205$ LWWHT, , , 0, 0,45, 0, 0.0,2.0,0,.1

Z206 LWWHT, , , , 0, 0,40,0,0.0,2.0,0,.1

Z207 LWWHT, , , 0, 0, 35, 0, 0.0,2.0,0,.1

Z208 LWWHT, , , 0, 0, 30,0,0.0,2.0,0,.1

Z209 LWWHT, , , 0, 0, 25, 0,0.0,2.0,0,.1

Z210 LWWHT, , , , 0, 0, 20,0,0.0,2.0,0,.1

HYDROMET STATIONS

BASIN NAME, DATA CODE, STA . NAME, WEIGHT, DATA CODE, STA. NAME, WEIGHT, ETC .

ZCH LWWHT, 4, SPRT, 100, 3, LWHP, 100

NAME, ELEV, SNW-WT, PX-TEMP

ZH SPRT, $400,100,35$

ZH ELET, 1633, 100,35

$\mathrm{ZH} \quad \mathrm{BUCT}, 2638,100,35$

$\mathrm{ZH} \quad \mathrm{CAYU}, 5300,100,35$

ZH STMP, 3958, 100,35

ZH FTLT, 280, 100,35

RUN CONTROL ( $L=$ PRINT INDIVIDUAL SNOWBAND RESULTS, S=SUPPRESS BASIN PRINTOUTS, BUPD=OPEN BULK FILE-ZBSTORE COMMANDS)

ZR L 7

REACH CHARACTERISTICS

$\begin{array}{ll}\mathrm{CC} 01 \text { WBQOBS } & 1 \\ \mathrm{CC} 01 \text { GRNOBS } & 1 \\ \mathrm{CC} 01 \text { WBCOBS } & 1 \\ \mathrm{CC} 01 \text { WCBOBS } & 1 \\ \mathrm{CC} 01 \text { WCQOBS } & 1 \\ \mathrm{CC} 01 \text { MCQOBS } & 1 \\ \mathrm{CC} 01 \text { LTDOBS } & 1 \\ \mathrm{CC} 01 \text { ORTOBS } & 1 \\ \mathrm{CC} 01 \text { CRFOBS } & 1 \\ \mathrm{CC} 01 \text { SOPOBS } & 1 \\ \mathrm{CC} 01 \text { PUYOBS } & 1\end{array}$

OBSERVED DISCHARGE-WHITE R. AT BUCKLEY

OBSERVED DISCHARGE-GREENWATER R.

OBSERVED DISCHARGE-WHITE R. BLW CLEARWATER

OBSERVED DISCHARGE-WHITE R. CANAL

OBS. CALCULATED DISCHARGE: WBCOBS - GRNOBS

OBS. CALCULATED DISCHARGE: WBQOBS + WCBOBS

OBSERVED DISCHARGE-LAKE TAPPS DIVERSION

OBSERVED DISCHARGE-PUYALLUP R. NR. ORTING

OBSERVED DISCHARGE-CARBON R. NR. FAIRFAX

OBSERVED DISCHARGE-SOUTH PRAIRIE CREEK

OBSERVED DISCHARGE-PUYALLUP R. AT PUYALLUP 


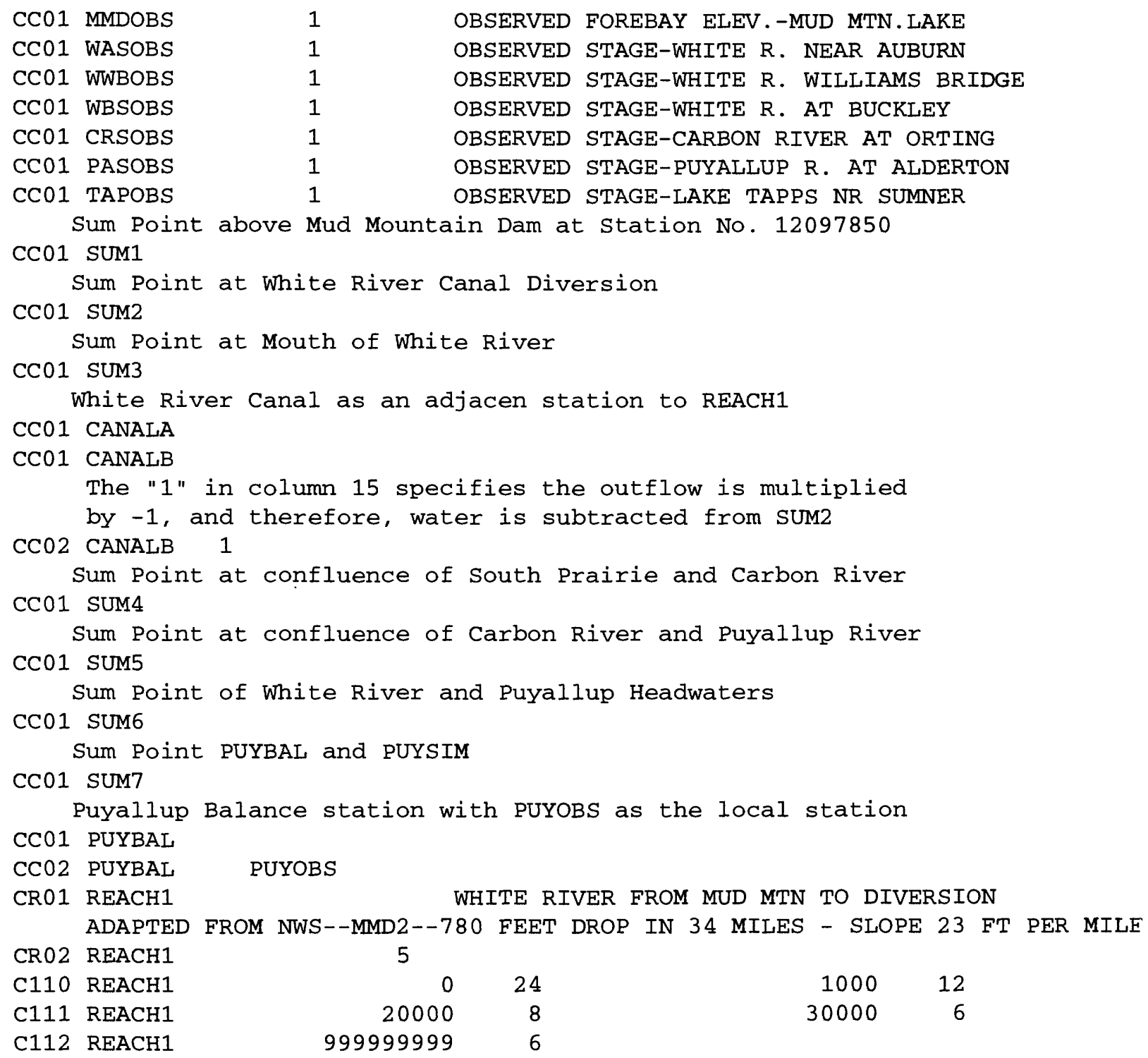

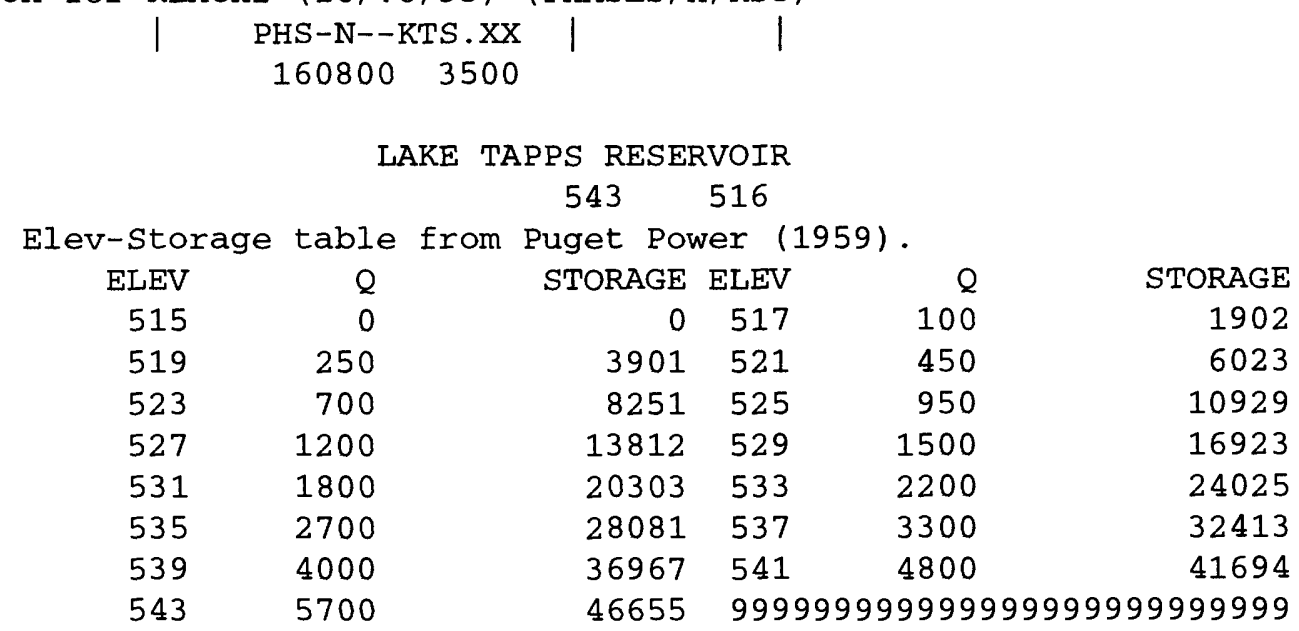




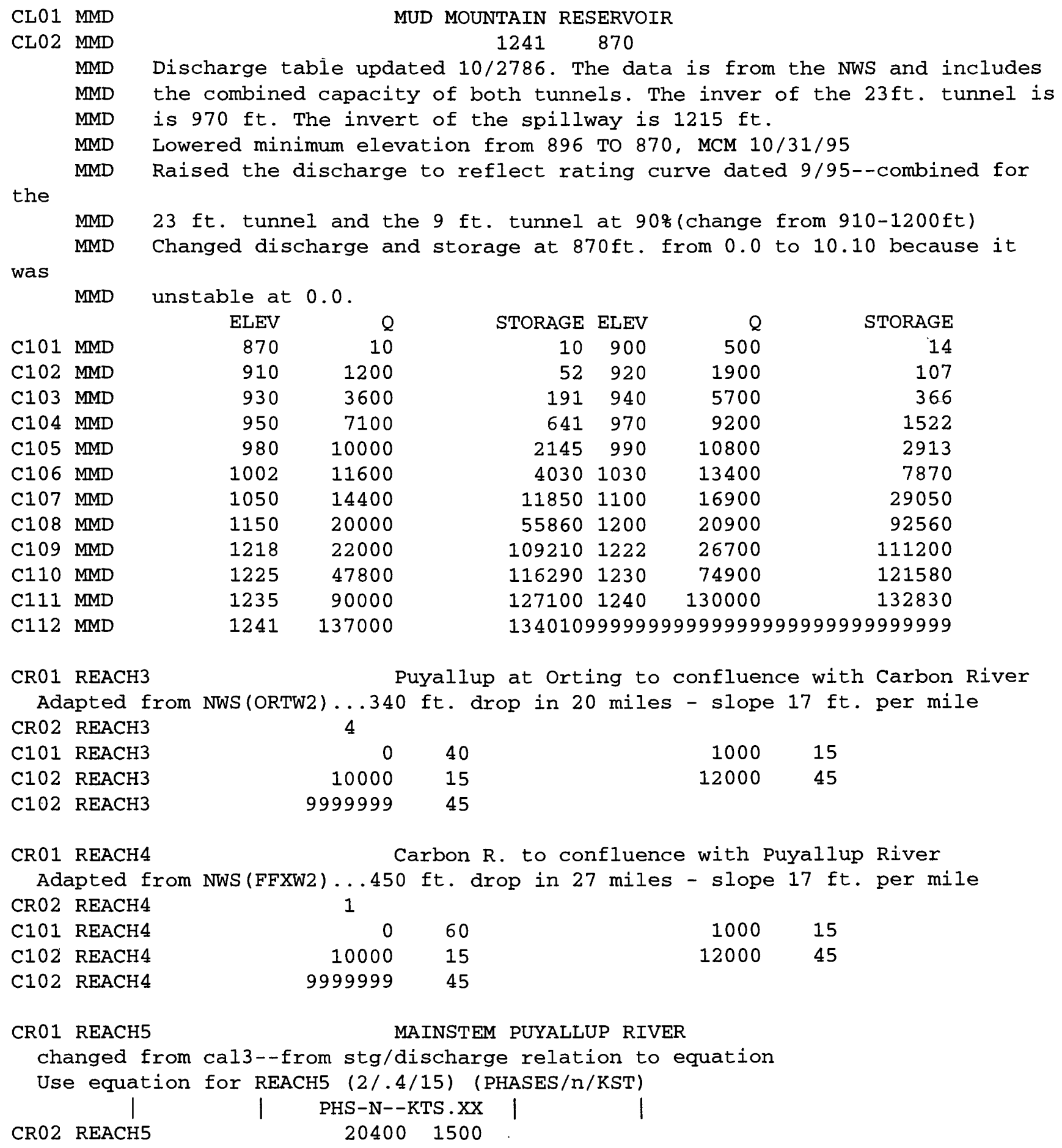


9 - SYSTEM CONFIGURATION CONTROL
U STA.N.
P D STA
D STA.
D STA.
D STA.
D STA.
D STA

$\mathrm{N}$

MAINSTEM

GRNWTR SUM1

GRNOBS

UPWHT SUM1

WBCOBS

WCQOBS

SUM1

MMD

MCQOBS

MMD

REACH1

REACH1 SUM2

WCBOBS

CANALA

CANALB

CANALB

TAPPS

SUM2

SUM2

WBQOBS

LWWHT

REACH2

REACH2

REACH2

SUM3

WASSTG

LTDOBS

TAPPS

SUM3

UPPUY

REACH3

ORSSTG

ORTOBS

REACH3

SUM5

CARBON SUM4

CRFOBS

SOPRE SUM4

SOPOBS

SUM4

REACH 4

SUM5

SUM5

SUM6

SUM6

REACH5

PUYOBS

CRSSTG

PASSTG

SUM5

SUM6

REACH5

PUYOBS

PUYBAL

After a "MAINSTEM" model run, the following run can be made to adjust REACH5 to the observed discharge values at Puyallup at Puyallup, Station No. 12101500.

(PUYBAL values saved as PUYDIF and REACH5 values

saved as PUYSIM after MAINSTEM model run)

$\begin{array}{lll}\text { N } & \text { ADJRCH5 } & \\ \text { P } & \text { PUYSIM } & \text { SUM7 } \\ \text { P } & \text { PUYDIF } & \text { SUM7 } \\ \text { P } & \text { SUM7 } & \text { REACH5 } \\ \text { P } & \text { REACH5 } & \text { PUSSTG } \\ \text { P } & \text { REACH5 } & \end{array}$


Ratings for river-stage sites

NOTE: The time series are saved as reservoir regulation time series (record type 100) with the ZSE <source> <target> command. The SSARR codes for the source and target are as follows:

$\begin{array}{ll}\text { Source Time Series } & \text { Target Time Series } \\ \text { ORSSTG } & \text { ORSSIM } \\ \text { CRSSTG } & \text { CRSSIM } \\ \text { PASSTG } & \text { PASSIM } \\ \text { PUSSTG } & \text { PUSSIM } \\ \text { WASSTG } & \text { WASSIM }\end{array}$

Puyallup River near Orting, Station No. 12093500

Adapted from rating No. 28 and current stage shift: .51SH a 4.00, .51FT a 5.15 AND $0.00 \mathrm{SH}$ a $10.02 \mathrm{FT}$. 8/18/97

CR01 ORSSTG PUYALLUP RIVER NEAR ORTING

CRO2 ORSSTG

$$
\text { \# PHASES } \mathrm{n}
$$

\begin{tabular}{llrrr} 
& \multicolumn{1}{c}{ STAGE } & \multicolumn{1}{c}{ Q } & \multicolumn{1}{c}{ TS } \\
& & $|---|$ & ---|| & $---\mid$ \\
C101 & ORSSTG & 300 & 0 & 10 \\
C101 & ORSSTG & 400 & 110 & 10 \\
C102 & ORSSTG & 600 & 1211 & 10 \\
C103 & ORSSTG & 800 & 4236 & 10 \\
C104 & ORSSTG & 1000 & 9517 & 10 \\
C105 & ORSSTG & 1200 & 18140 & 10 \\
C106 & ORSSTG & 99999999999999 & 10
\end{tabular}

\begin{tabular}{rrr} 
STAGE & \multicolumn{1}{c}{ Q } & \multicolumn{1}{c}{ TS } \\
\hline 399 & 108 & 10 \\
500 & 483 & 10 \\
700 & 2469 & 10 \\
900 & 6575 & 10 \\
1100 & 13470 & 10 \\
1300 & 23840 & 10
\end{tabular}

Puyallup River at Puyallup, Station No. 12101500

Adapted from rating No. 11 and current stage shift: -.78 shift below $19.00 \mathrm{ft}$. prorated to -1.20 shift at $24.50 \mathrm{ft}$. $8 / 18 / 97$

CR01 PUSSTG

PUYALLUP RIVER AT PUYALLUP

CR02 PUSSTG

C101 PUSSTG

C102 PUSSTG

C103 PUSSTG

C104 PUSSTG

C105 PUSSTG

C106 PUSSTG

C107 PUSSTG

\begin{tabular}{rrr}
\multicolumn{2}{c}{ \#PHASES } & \\
& 1 & \\
& 1 & \\
STAGE & $\mathbf{Q}$ & \multicolumn{2}{c}{ TS } \\
$|---|$ & $---\mid$ & $----\mid$ \\
854 & 348 & 10 \\
1200 & 3225 & 10 \\
1600 & 9530 & 10 \\
2000 & 18060 & 10 \\
2400 & 28040 & 10 \\
2800 & 40550 & 10 \\
3170 & 53850 & 10
\end{tabular}

\begin{tabular}{rrr} 
STAGE & \multicolumn{1}{c}{$Q$} & TS \\
$|---| \mid$ & $---\mid$ & $---\mid$ \\
1000 & 1163 & 10 \\
1400 & 6045 & 10 \\
1800 & 13620 & 10 \\
2200 & 22820 & 10 \\
2600 & 34000 & 10 \\
3000 & 47560 & 10 \\
99999999999999999999
\end{tabular}

Puyallup River at Alderton, Station No. 12096500

ADAPTED FROM RATING \#6 1/22/97

CR01 PASSTG

PUYALLUP RIVER AT ALDERTON

CRO2 PASSTG

C101 PASSTG

C102 PASSTG

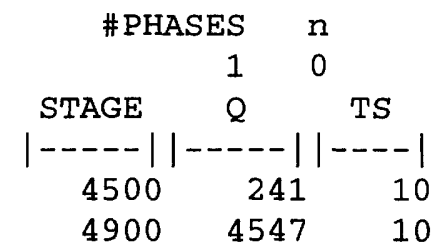

\begin{tabular}{ccr} 
STAGE & Q & \multicolumn{1}{c}{ TS } \\
$|---| \mid$ & ---|| & $---\mid$ \\
4700 & 1704 & 10 \\
5100 & 8805 & 10
\end{tabular}




$\begin{array}{llllllll}\text { C103 } & \text { PASSTG } & 5300 & 14500 & 10 & 5500 & 21640 & 10 \\ \text { C104 } & \text { PASSTG } & 5700 & 30250 & 10 & 5900 & 40340 & 10 \\ \text { C105 } & \text { PASSTG } & 6100 & 51920 & 10 & 6300 & 64990 & 10 \\ \text { C106 } & \text { PASSTG } & 6500 & 79560 & 10 & 99999999999999 & 10\end{array}$

Carbon River at orting, Station No. 12095690

Adapted from rating 3 and current shifts: $0.48 \mathrm{sh}$ below $24.20 \mathrm{ft}$. and zero shift at $26.80 \mathrm{ft}$. and abv. 1/22/97

CRO1 CRSSTG

CARBON RIVER AT ORTING

\begin{tabular}{|c|c|c|c|c|}
\hline \multirow{3}{*}{$\mathrm{CRO} 2$} & \multirow{3}{*}{ CRSSTG } & \\
\hline & & & 1 & 0 \\
\hline & & $\begin{array}{l}\text { STAGE } \\
----1\end{array}$ & $Q$ & ---1 \\
\hline C101 & CRSSTG & 2250 & 213 & 10 \\
\hline C102 & CRSSTG & 2600 & 3450 & 10 \\
\hline C103 & CRSSTG & 2800 & 7311 & 10 \\
\hline C104 & CRSSTG & 3000 & 13100 & 10 \\
\hline$C 105$ & CRSSTG & 3200 & 20550 & 10 \\
\hline
\end{tabular}

$\begin{array}{crr}\text { STAGE } & \text { Q } & \\ |---| \mid & ---\mid & ---\mid \\ 2400 & 1193 & 10 \\ 2700 & 5046 & 10 \\ 2900 & 9994 & 10 \\ 3100 & 16610 & 10 \\ 99999999999999 & 10\end{array}$

White River $\mathrm{nr}$. Auburn, Station No. 12100496

Adapted from rating 3 and current shifts: -2.32 sh throughout the entire range of the rating $1 / 22 / 97$

CR01 WASSTG WHITE RIVER AT AUBURN

CR02 WASSTG

C101 WASSTG

C102 WASSTG

C103 WASSTG

C104 WASSTG

C105 WASSTG

C106 WASSTG

\begin{tabular}{crr} 
\#PHASES & $\mathrm{n}$ \\
& 1 & 0 \\
STAGE & $\mathrm{Q}$ & \\
\hline---|| & ---|| & --1 \\
7702 & 0 & 10 \\
7900 & 1033 & 10 \\
8100 & 4002 & 10 \\
8300 & 8815 & 10 \\
8500 & 15420 & 10 \\
8732 & 25300 & 10
\end{tabular}

\begin{tabular}{|c|c|c|}
\hline \multicolumn{3}{|c|}{ STAGE $Q$} \\
\hline$|-----| \mid$ & $\cdots$ & $\cdots$ \\
\hline 7800 & 264 & \\
\hline 8000 & 2283 & \\
\hline 8200 & 6181 & \\
\hline 8400 & 11900 & \\
\hline 8600 & 19390 & \\
\hline 9999999 & 999999 & \\
\hline
\end{tabular}


Puyallup River Model Tabled Characteristics

Puyallup River Model Tabled Characteristics

ZCT THREE DIMENSION TABLE OR FUNCTION

NAME, WORD2, WORD3, WORD4, WORD5, ETC

ZCT, MRCR $, 3,0,0.02,0.025,100,0.03,0.025,300,0.06,0.025,999,0.06,0.025$

ZCT , MRCR2 $, 3,0,0.04,0.025,100,0.06,0.025,300,0.06,0.025,999,0.06,0.025$

$\mathrm{ZCT}, \mathrm{MRCR} 3,3,0,0.08,0.025,100,0.10,0.025,300,0.10,0.025,999,0.10,0.025$

ZCT TWO DIMENSION TABLE OR FUNCTION

NAME, WORD2, WORD3, WORD4, WORD5, ETC

ZCT , ELPGWT , 2,1750, 72.0, 2250,83.6,2750,94.1,3250,100.3, 3750,103.0,4250,104.2,

ZCT, ELPGWT, 4750,105.1,5500,103.8,7000,99.6,8000,99.6

ZCT, ELPUWT $, 2,1250,76.6,1750,79.2,2250,83.4,2750,87.6,3250,91.1,3750,94.9$,

ZCT, ELPUWT, $4250,98.3,4750,102.5,5500,108.9,7000,127.7,11000,166.4,16000,166.4$

ZCT, ELPLWT, 2 , 250, 83 .6, 750, 86.4,1250,102.0,1750,112.9,2250,130.2,2750,141.7,

ZCT, ELPLWT, $3250,143.3,3750,142.9,4250,139.1,4750,143.1,5000,143.1$

ZCT, ELPSOP , 2 , 250, 75.5, 750, 77.8,1250,86.1,1750,96.7,2250,108.2,2750,118.3,3250,

ZCT, ELPSOP, $122.7,3750,126.0,4250,128.1,4750,132.2,5500,135.4,7000,135.4$

$\mathrm{ZCT}, \mathrm{ELPCRB}, 2,1250,66.3,1750,71.5,2250,83.0,2750,86.6,3250,93.8,3750,100.1$,

$\mathrm{ZCT}, \mathrm{ELPCRB}, 4250,102.6,4750,105.2,5500,112.9,7000,127.5,11000,148.5,16000,148.5$

ZCT, ELPUPU, $2,250,53.2,750,54.7,1250,63.4,1750,74.6,2250,89.5,2750,103.1,3250$,

ZCT, ELPUPU, 114.9, 3750,118.8,4250,122.0,4750,127.1,5500,134.9, 7000,146.3,11000,

ZCT, ELPUPU, $163.7,16000,163.7$

ZCT, ELPLPU, $2,250,87.5,750,92.4,1250,106.6,1750,118.5,2250,133.9,2750,154.1$,

ZCT, ELPLPU, $3250,177.7,3750,192.0$

NAME, WORD2, WORD3, WORD4, WORD5, ETC

ZCT, ELPUW, $2,1250,76.6,1750,79.2,2250,83.4,2750,87.6,3250,91.1,3750,94.9$,

ZCT, ELPUW, $4250,95.7,4750,88.1,5500,81.8,7000,88.1,11000,88.1,16000,88.1$

ZCT, ELPCR, $2,1250,66.3,1750,71.5,2250,83.0,2750,86.6,3250,93.8,3750,100.1$,

$\mathrm{ZCT}, \mathrm{ELPCR}, 4250,97.3,4750,92.8,5500,84.0,7000,77.4,11000,77.4,16000,77.4$

ZCT, ELPUP , 2, 250, 53.2, 750, 54.7,1250,63.4,1750,74.6,2250,89.5,2750,103.1,3250,

ZCT, ELPUP, $114.9,3750,118.8,4250,114.2,4750,108.2,5500,102.2,7000,96.2,11000$,

ZCT, ELPUP, $96.2,16000,96.2$

ZCT, SM0 7, 2, 0, 10,2.5,20,5,36,12,100,15,100,999,100

ZCT, SM08, 2, 0,10,2.5,20,5,36,8,60,10,74,12,86,14,100,999, 100

ZCT, SM10, 2, 0, 15,2.5,23,5,36,12,100,15,100,999,100

$\mathrm{ZCT}, \mathrm{SM1} 2,2,0,15,2,20,4,30,6,45,8,70,9,88,10,95,11,100,999,100$

$\mathrm{ZCT}, \operatorname{SM1} 4,2,0,20,2,30,4,40,6,60,7,80,8,100,999,100$

$\mathrm{ZCT}, \mathrm{SM} 15,2,0,20,2,30,4,40,6,54,7,61,8,68,10,80,12,90,14,100,999,100$

$\mathrm{ZCT}, \operatorname{SM} 16,2,0,15,2,20,4,30,6,52,8,76,9,88,10,95,11,100,999,100$

$\mathrm{ZCT}, \operatorname{SM} 17,2,0,10,2.5,20,5,36,6,50,7,65,8,76,9,82,10,88,12,96,14,100,999,100$

$\mathrm{ZCT}, \mathrm{SM} 20,2,0,20,2,30,4,40,6,60,7,70,8,75,10,80,12,85,14,90,16,95,18,100,99,100$

ZCT, SM21, 2,0,10,2,15,4,30,6,60,7,70,8,75,10,79,12,83,14,87,16,90,20,100,99,100

$\mathrm{ZCT}, \mathrm{BI} 37,2,0,80, .1,57, .2,45, .3,37, .4,32, .5,29, .6,27,1.0,20,2.0,10,9999,10$

$\mathrm{ZCT}, \mathrm{BI} 31,2,0,75, .2,60, .4,48, .6,37, .8,31,1.0,27,1.2,25,9999,25$ 
ZCT, BI79, 2,0,90,.2,75,.4,63,.6,52,.8,46, 1.0,45,1.2,45,9999,45

ZCT, SS80, 2,0,0,.02,.006,.04,.014,.06,.024,.08,.036,.1,.05,.5,.37, 1.0,.77,100, ZCT, SS80,99.77

$\mathrm{ZCT}, \mathrm{SS} 07,2,0,0, .02, .004, .04, .010, .06, .018, .08, .028, .1, .04, .12, .054, .14$,

$\mathrm{ZCT}, \mathrm{SS} 07, .07,100,99.93$

$\mathrm{ZCT}, \mathrm{KE0} 3,2,0,100, .1, .70, .4,30, .6,20,1.0,10,2.0,0.0,999,0.0$

$\mathrm{ZCT}, \mathrm{KE0} 4,2,0,100, .5,30,2.0,0.0,999,0.0$

ZCT, ETPPUY $, 2,-100,0,32,0,40, .023,50, .058,60, .097,70, .137,80, .179,90, .222,100$, ZCT, ETPPUY, . 266

ZCT, ETPMMD , 2,-100,0,32,0,40,.028,50,.065,60,.103,70,.140,80,.179,90,.216,100,

ZCT, ETPMMD, . 255

$\mathrm{ZCT}, \mathrm{DKE}, 2,0,0,3,50,6,90,10,100,9999,100$

ZCT, ETM $, 2,1,77,2,80,3,102,4,114,5,130,6,132,7,133,8,122,9,104$,

$\mathrm{ZCT}, \mathrm{ETM}, 10,93,11,78,12,73,13,77$

$\mathrm{ZCT}$, GMLT $, 2,1, .004,2, .01,3, .02,4, .025,5, .03,10, .01,11, .005,13, .004$

ZCT, MRPCT, $2,1,31,2,37,3,53,4,70,5,87,6,100,7,100,8,91,9,76,10,58,11,41,12,32,13$, ZCT, MRPCT, $31,9999,31$

ZCT, ATTR1, 2, 1, 2, 2, 5, 3, 11, 4, 18, 5, 26, 6, 34, 7, 41,8,49,9,56, 10,63, 11,68, 12, 74, 13,78

ZCT, ATTR1, 14, 82, 15, 86, 16, 89, 17,92,18,4,19,95,20,97,21,98,22,99,23,99,24,100

RELATION FOR ADJACENT STATION CANALA--WHITE R. CANAL DIVERSION AS A

FUNCTION OF FLOW IN REACH1 (WHITE R. NR. BUCKLEY)

$\mathrm{ZCT}, \mathrm{CDIV}, 2,150,0,400,265,2000,1500,8000,1500,12000,0,60000,0$ 